\title{
Oestrogen and progesterone receptors in the human uterus : immunocytochemical analysis in normal, hyperplastic, and neoplastic endometrium
}

Citation for published version (APA):

Snijders, M. P. M. L. (1992). Oestrogen and progesterone receptors in the human uterus : immunocytochemical analysis in normal, hyperplastic, and neoplastic endometrium. [Doctoral Thesis, Maastricht University]. Rijksuniversiteit Limburg. https://doi.org/10.26481/dis.19920612ms

Document status and date:

Published: 01/01/1992

DOI:

10.26481/dis.19920612ms

Document Version:

Publisher's PDF, also known as Version of record

Please check the document version of this publication:

- A submitted manuscript is the version of the article upon submission and before peer-review. There can be important differences between the submitted version and the official published version of record.

People interested in the research are advised to contact the author for the final version of the publication, or visit the DOI to the publisher's website.

- The final author version and the galley proof are versions of the publication after peer review.

- The final published version features the final layout of the paper including the volume, issue and page numbers.

Link to publication

\footnotetext{
General rights rights.

- You may freely distribute the URL identifying the publication in the public portal. please follow below link for the End User Agreement:

www.umlib.nl/taverne-license

Take down policy

If you believe that this document breaches copyright please contact us at:

repository@maastrichtuniversity.nl

providing details and we will investigate your claim.
}

Copyright and moral rights for the publications made accessible in the public portal are retained by the authors and/or other copyright owners and it is a condition of accessing publications that users recognise and abide by the legal requirements associated with these

- Users may download and print one copy of any publication from the public portal for the purpose of private study or research.

- You may not further distribute the material or use it for any profit-making activity or commercial gain

If the publication is distributed under the terms of Article $25 \mathrm{fa}$ of the Dutch Copyright Act, indicated by the "Taverne" license above, 


\title{
OESTROGEN AND PROGESTERONE RECEPTORS IN THE HUMAN UTERUS
}

\author{
Immunocytochemical analysis \\ in normal, hyperplastic, and neoplastic \\ endometrium
}




\title{
OESTROGEN AND PROGESTERONE RECEPTORS IN THE HUMAN UTERUS
}

\section{Immunocytochemical analysis in normal, hyperplastic, and neoplastic endometrium}

\author{
Proefschrift
}

ter verkrijging van de graad van doctor aan de Rijksuniversiteit Limburg te Maastricht, op gezag van de Rector Magnificus, Prof. mr M.J. Cohen, volgens het besluit van het College van Dekanen, in het openbaar te verdedigen op vrijdag 12 juni 1992 om 14.00 uur

door

Marcus Peter Marie Louis Snijders geboren te Nieuwenhagen in 1959 
Promotores

Proff, dr F.T. Bosman, EU Rotterdam

Prof. dr J. de Haan

Co-promotor

Dr A.F.P.M. de Goeij

\section{Beoordelingscommissie}

Proff, dr P.J. Brombacher (voorzitter)

Prof. dr J,G. Aalders, RU Groningen

Prof. dr J.W. Arends

Prof, dr A.C. Nieuwenhuijzen Kruseman

Prof. dr J.H.H. Thijssen, RU Utrecht 
'To most..., the receptor is like a beautiful but remore lady. He has written her many a letter and quite often she has answered the letters. From these answers he has built himself an image of this fair lady. He cannot, however, truly claim ever to have seen her, although one day he may do so' (de Jong, 1964).

Time for dreaming is over. She is in our arms, undoubtedly a confusing experience. Reality definitely differs but is surely not less exciting than the dream' (Ariëns, 1991). 


\section{CIP-GEGEVENS KONINKLIJKE BIBLIOTHEEK, DEN HAAG}

Snijders, Marcus Peter Marie Louis

Oestrogen and progesterone receptors in the human uterus:

immunocytochemical analysis in normal, hyperplastic, and neoplastic endometrium /

Marcus Peter Marie Louis Snijders. - [S.1. : s.n.]. - II1.

Proefschrift Maastricht. - Met lit. opg. - Met samenvatting in het Nederlands.

ISBN 90-9005055-8

Trefw. : oestrogeen-receptoren / progesteron-receptoren / endometrium; onderzoek. 


\section{Contents}

Voorwoord.

Abbreviations

CHAPTER 1

General Introduction

CHAPTER 2

Is immunohistochemical analysis of oestrogen and progesterone receptors in endometrial carcinoma superior to the radioligand binding assay?

CHAPTER 3

Immunocytochemical analysis of oestrogen and progesterone receptors in paraffin sections

CHAPTER 4

Immunocytochemical analysis of oestrogen and progesterone receptors in the normal human uterus throughout the menstrual cycle and after menopause

CHAPTER 5

Oestrogen and progesterone receptor immunocytochemistry in human hyperplastic and neoplastic endometrium

CHAPTER 6

Preoperative oestrogen and progesterone receptor immunocytochemistry in endometrial carcinoma: correlation with clinical and histopathological parameters 
Prognostic relevance of oestrogen and progesterone receptor immunocytochemistry in endometrial carcinoma

CHAPTER 8

General Discussion

Summary

Samenvatting

Curriculum Vitae 


\section{Voorwoord}

Het in dit proefschrift beschreven onderzoek is uitgevoerd binnen de afdelingen Gynaecologie en Pathologie van het De Wever-Ziekenhuis Heerlen, in samenwerking met de afdeling Pathologie van het academisch ziekenhuis Maastricht.

Hulp bij het daadwerkelijke onderzoek en de beschrijving van resultaten was onontbeerlijk. Zonder iemand te kort willen doen richt ik gaarne een speciaal woord van dank tot de volgende personen:

- Hooggeleerde Bosman, alhoewel van enige afstand, u hebt de voortgang verzekerd. Uw commentaren waren kort en krachtig, maar altijd prachtig!

- Hooggeleerde de Haan, alhoewel pas in een latere fase bij dit proefschrift betrokken, $u$ hebt $\mathrm{u}$ in ijltempo verdiept in "de receptor." Danken wil ik u vooral voor de genoten opleiding binnen de door u geleide kliniek te Maastricht: verloskunde gebaseerd op 'nil nocere' is een hele kunst.

- Zeergeleerde de Goeij, 'dear Anthony', moderator van het onderzoek gedurende al die jaren. Je fijnzinnige manier van sturen (als stroma voor epitheel?), waarbij je de onderzoeker geheel in zijn waarde liet, was van een zeldzaam niveau.

- Zeergeleerde Koudstaal, Johan, jouw inzet, waarmee je de praktische voorwaarden schiep voor de gehele studie, wordt zeer gewaardeerd.

- Mevrouw Debets-Te Baerts, Marij, jij hebt de receptor immunocytochemie geoptimaliseerd en met grote ijver en accuratesse uitgevoerd. Je interesse in vernieuwende technieken is bewonderenswaardig, mede gezien de niet aflatende zorg voor familie en menig "padvinder'!

- De heer Rousch, Mat, vanaf het prille begin verleende je ondersteuning, enerzijds aan het onderzoek zelf, anderzijds aan de interpretatie en presentatie van resultaten. Jouw oog voor detail bracht maar al te vaak licht in mijn duisternis!

- Zeergeleerde Theunissen, Paul, je nauwkeurige herbeoordelling van enige honderden coupes en je medewerking bij publicatie van hoofdstuk 3 waren uiterst waardevol voor de voortgang van het onderzoek.

- Hooggeleerde leden van de beoordelingscommissie, u allen dank ik voor de vlotte toetsing van het manuscript. 
- Zeergeleerde Schellekens, Louis, initiator van het receptoronderzoek. Eerst als inspirerend opleider te Heerlen, maar ook nadien vanuit Nijmegen was je woortdurende belangstelling hartverwarmend.

- Zeergeleerde Stoot, Jan, als gynaecoloog-oncoloog heb je het receptoronderzoek in woord èn daad ondersteund. Je manier van werken is voorbeeldig, een opleider waardig.

- (Zeer)geleerde leden van de Maatschap Gynaecologie en Verloskunde van het De Wever-Ziekenhuis, u allen dank ik voor het genoten vertrouwen en de daadwerkelijke ondersteuning bij het onderzoek van patiënten, behandeld binnen uw kliniek.

- Medewerk(st)ers van de afdeling Pathologie van het De Wever-Ziekenhuis, jullie aller inzet voor het receptoronderzoek was geweldig: de weefselopslag, de verwerking, het snijden, kleuren, rubriceren etcetera, alles was ten alle tijde perfect verzorgd. Hopelijk blijft jullie afdeling tot in lengte van dagen zo goed geölied functioneren!

- Medewerksters van secretariaat en balie wan de afdeling Gynaecologie van het De Wever Ziekenhuis, jullie aller bereidheid tot het opzoeken (en altijd vinden!) van de betreffende patiëntenkaarten, al was het in de meest obscure archiefplaatsen, was onuitputtelijk. Hulde!

- Mevrouw Clignet en mevrouw Vincent, bibliothecaressen van het De WeverZiekenhuis, Romy en Miriam, jullie verzorgden vlot en uiterst correct de gevraagde literatuur.

- Mevrouw Janssen en mevrouw Gerrits, Monique en Petra, jullie beiden dank ik voor de secretariële ondersteuning tijdens de laatste onderzoeksjaren in het academisch ziekenhuis Maastricht en het st Maartens Gasthuis, Venlo.

- (Zeer)geleerde maatschapsleden Gynaecologie van het st Maartens Gasthuis Venlo, u allen dank ik voor uw geduld en medewerking.

- Lieve ouders, Fien en Léon, jullie steun was er gewoon. In allerlei opzichten. Merci.

- Liefste Nicolle, jouw zorg en medeleven waren van vitaal belang. Voor mij en voor het onderzoek. Mijn dank is onbeschrijflijk groot. 


\section{Abbreviations}

\begin{tabular}{|c|c|}
\hline $\mathrm{ABC}$ & avidin biotin (peroxidase) complex \\
\hline BSA & bovine serum albumin \\
\hline CAS & Cell Analysis System \\
\hline c.i. & confidence interval \\
\hline $\mathrm{DAB}$ & diaminobenzidine \\
\hline $\mathrm{E}_{\mathrm{I}}$ & oestrone \\
\hline $\mathrm{E}_{2}$ & 17 B-oestradiol \\
\hline $\mathrm{E}_{3}$ & oestriol \\
\hline EORTC & European Organisation for Research and Treatment of Cancer \\
\hline $\mathrm{f}$ & femto $\left(10^{-15}\right)$ \\
\hline FIGO & International Federation of Gynecology and Obstetrics \\
\hline Gy & Gray (measure of radiotherapeutic dose-intensity) \\
\hline $\mathrm{kD}$ & kilodalton \\
\hline $\mathrm{K}_{\mathrm{d}}$ & dissociation constant \\
\hline M & $\mathrm{mol} / \|$ \\
\hline $\mathrm{n}$ & nano $\left(10^{-9}\right)$ \\
\hline OR & oestrogen receptor \\
\hline $\mathrm{p}$ & $\operatorname{pico}\left(10^{-12}\right)$ \\
\hline $\mathbf{P}$ & probability value (significance level) obtained from a hypothesis test \\
\hline PAP & peroxidase anti-peroxidase \\
\hline PBS & phosphate-buffered saline \\
\hline PR & progesterone receptor \\
\hline$\%$ Pos. Area & $\begin{array}{l}\text { percentage positive area (measure of immunocylochemical receptor } \\
\text { staining) }\end{array}$ \\
\hline$r$ & Pearson's (product moment) correlation coefficient \\
\hline RT & room temperature \\
\hline R 5020 & (synthetic) 19 norprogesterone $=$ promegestone \\
\hline SD & standard deviation of a set of observations \\
\hline SEM & standard error of the mean \\
\hline$\Sigma$ & sum of \\
\hline
\end{tabular}



CHAPTER 1

\section{General Introduction}




\subsection{Introduction}

Endometrial cancer has become the most frequent gynaecological cancer in the European Community (EC) with approximately 24,000 new cases per year. Although most patients present with early stage disease, more than 8,000 annual deaths in the EC are attributed to endometrial carcinoma (1). To improve the survival rate, adjuvant treatment modalities have been introduced in addition to surgery. However, in worldwide cancer statistics, no significant improvement in endometrial cancer prognosis has been reported over the past 25 years (2). A more individualized treatment based on specific tumour behaviour seems to be an appropiate way to ameliorate the prognosis of patients with endometrial carcinoma.

Several parameters related with unfavourable tumour behaviour such as black race, postmenopausal status, advanced age and genetic predisposition have been recognized as constitutional factors $(3,4)$. Deep myometrial invasion, advanced FIGO or pathological stage, lymph node metastasis and positive peritoneal cytology are known as clinical factors $(5,6)$. Certain uncommon tumourtypes poor histological differentiation and vascular space involvement have been established as adverse histopathological factors $(3,6-9)$. At the cellular level, the results of nuclear grading, morphometry and flow cytometry may identify subgroups with more or less predictable behaviour in the near future $(10,11)$.

From the early 1970's onwards, a series of reports have focussed attention on the relationship between steroid hormones and malignant proliferation of the endometrium. Both endogenous and exogenous oestrogens have been recognized as growthpromotors in the multistep process of endometrial carcinogenesis (12-16). Conversely, progestogens have appeared to be essential for endometrial differentiation and maturation. Treatment with progestogens in addition to oestrogens has been shown to protect against the development of endometrial hyperplasia and neoplasia (16-18). However, both the mechanism and relative importance of oestrogen and progestogen effects on abnormal endometrial proliferation are not entirely clear. Kurman and Norris (3) distinguish between two different forms of endometrial cancer: a low-grade neoplasm that appears oestrogen-responsive and occurs in younger, perimenopausal women and a second form unrelated to oestrogenic stimulation that occurs in older, postmenopatisal women. The latter is often characterized by a far more aggressive behaviour than the oestrogen-related neoplasm $(19,20)$. Also, progestational therapy may be successfull in the prevention and treatment of only a subgroup of endometrial proliferative disorders $(21,22)$. To shed more light on this problem the analysis of steroid hormone-responsiveness might be a useful approach.

As physiological growth and function of the uterus are regulated by oestrogens and progesterone and malignant transformation may be regarded as a disturbance of normal regulation, knowledge of hormonal regulation of growth and differentiation in the normal uterus is essential before growth disturbances, including malignancy 
can be investigated. In this respect, several studies on plasma and tissue steroid levels have provided valuable information (14,23-27). However, no significant differences in the synthesis rate, blood and tissue concentration of steroids between patients with normal, hyperplastic, or neoplastic endometrium have been found. Most of the tissue studies to date have been done on the whole endometrium or uterus, and the results present only a composite picture of the steroid-induced changes occurring in the different cell types. At the level of the uterine target cells, oestrogen and progesterone action is transduced and mediated by specific proteins i.e. the oestrogen receptor (OR) and the progesterone receptor (PR). In addition, steroids may be metabolized enzymatically. The uterus is a heterogeneous organ, composed of various cell types and the biological potency of steroid hormones within the different cell types is strongly determined by receptor binding and eventual metabollism of steroids in the cells (28). Receptor presence and concentration in the various uterine cells indicate potential responsiveness to the particular steroid hormones. We postulate, that analysis of OR and PR at cellular level may yield more specific information on the local hormonal relationships involved with endometrial tumour behaviour.

Before the aims of this thesis are defined more explicitly (chapter 1.6), some introductory remarks are made regarding oestrogen and progesterone effects on uterine cells (chapter 1.2), steroid receptors: structure and function (chapter 1.3), methods of steroid receptor analysis (chapter 1.4) and results of receptor studies in the human uterus hitherto (chapter 1.5).

\subsection{Oestrogen and progesterone effects on uterine cells}

The principal steroid hormones which regulate uterine function are 17 B-oestradiol $\left(E_{2}\right)$ as the most potent oestrogen, oestrone $\left(E_{1}\right)$ with approximately $20 \%$, and oestriol $\left(\mathrm{E}_{3}\right)$ with only $5 \%$ relative activity when compared to $\mathrm{E}_{2^{\prime}}$ Progesterone is the most active progestogen; when compared to progesterone the relative potencies of $20 \alpha$-dihydroprogesterone and $17 \alpha$-hydroxyprogesterone are $15 \%$ and $5 \%$, respectively (29). During the reproductive years, these steroid hormones govern the normal endometrial cycle, which is characterized by specific function-related morphological changes of both the glandular epithelial and stromal cells, summarized as regeneration, proliferation, secretory differentiation, predecidualization and menstruation. Although both endometrial cell types are functionally receptive to the changing endocrine milieu, they reveal various patterns of growth and differentiation which differ in extent as well as in time.

Increased proliferation and synthetic activity are characteristic oestrogen-induced effects in all uterine tissues. Cell proliferation is observed in the glandular epithelial, stromal, and muscle cells during the proliferative phases of the menstrual cycle and 
is reflected in mitotic activity, increased RNA, DNA, and protein synthesis, and an increased rate of metabolism, which indicate oestrogen-induced growth $(25,30-32)$. Interactions between the stromal and epithelial cells appear to be stimulated by oestrogens during the proliferative phase of the menstrual cycle. Roberts et al. (33) have described complex interactions, studied at the ultrastructural level: (a) an increase in the number and size of lamina densa disruptions, (b) an increase in the number and size of gap junctions, (c) an increase in the number and complexity of epithelial cell projections that extend through the lamina densa, and (d) an increase in close contacts between stromal and epithelial cells. Biochemical studies have shown that the synthesis of a series of endometrial chemical factors is stimulated by oestrogens (34): e.g. prostaglandins from the glandular epithelial cells (35), paracrine and autocrine growth factors (a.o. epidermal growth factor $\{E G F\}$ and transforming growth factor $\alpha$ (TGF $\alpha$ ) from the glandular epithelial cells, and insulin-like growth factor I (IGF II\} from the stromal cells $\{35,36\}$ ), as well as growth factor receptors $(36,37)$ and oncoproteins (38). Prolonged oestrogen stimulation may promote abnormal proliferation, as has been reported in several studies confirming the presence of dose-response and duration-response relationships $(5,12-18,31,39)$, and the existence of increased risk in certain clinical subgroups $(3,5,40)$.

Progesterone effects are characterized firstly by modulation of the growth-stimulatory effects of oestrogens, then cellular differentiation and finally atrophy (41). Modulation of oestrogen effects is achieved in several ways, including induction of specific enzymes in the endometrial stroma (e.g. aromatase $\{41-43\}$ ) and glandular epithelium (e.g. $E_{2}$-dehydrogenase $\{41,44\}$ ) which are involved in local oestrogen synthesis and metabolism, lowering and/or inactivation of OR and PR (see chapter 1.4), inhibiting effects on oestrogen-induced prostaglandins, growth factors, growth factor receptors and oncoproteins (34-38,41), and direct antagonism of oestrogen action at the postreceptor level. In the oestrogen-primed endometrium the glandular epithelial cells show secretory differentiation by progesterone action, while the small fibroblast-like stromal cells differentiate into large epithelioid cells (predecidualization). Endometrial differentiation during the progesterone-induced secretory phase appears to be associated with a decreased contact between stromal and glandular epithelial cells $(33,45)$ and a progressive basement membrane production around the stromal cells (46). In addition to secretion of a series of specific endometrial proteins (a.o. prolactin $\{34,43\}$, renin $(47\}$ and insulin-like growth factor binding protein [IGFBP; 35,48$\}$ from the stromal cells and progestogen-associated endometrial protein [PEP; 34,49 ] from the glandular epithellial cells), progesterone has been reported to stimulate the production of glycogens and carbohydrates (34), several autocrine and paracrine growth factors (e.g. platelet activating factor $\{\mathrm{PAF} ; 50\}$ ) and growth factor receptors (EGF and IGF-I receptors $\{51\})$. The amount of progesterone necessary to produce the typical endometrial effects is influenced by the previous or simultaneous oestrogenic stimulation, as well as the duration of stimulation by progesterone. Atrophy, however, will be the ultimate result of prolonged progesterone exposition.

The proliferative disorders of the endometrium are regarded as a morphological continuum $(3,7)$. An increase in the number and/or volume of epithelial glands 
relative to the stroma is defined as hyperpasia. Atypical hyperplasia is characterized by a varying degree of nuclear atypia of the glandular epithelium and an early desmoplastic or fibrous stromal response. Adenocarcinoma is defined by a definite invasion of the stroma by the neoplastic epithelium. In contrast to most internal organs which are composed of an ectodermal or entodermal epithelium and a mesodermal stroma, both endometrial stroma and epithelium are of mesodermal origin (52). The stromal component of the genital tract has not yet been studied thoroughly, but appears of major importance $(53,54)$. The picture emerging from the scarce studies performed in this field (55-59), is one of mutual dependence of epithelium and stroma for control of growth and functional development by steroid hormones. Epithelial growth, which is generally dependent on mesenchymal support, can be controlled by mesenchymal factors regulated by hormonal steroids in stromal cells (34-36,55-58). Conversely, the epithelium may govern the development of mesenchymal responsiveness to these hormones $(48,50,59)$. We postulate that the interplay of stromal and epithelial cells may be crucial for development of malignancy in the endometrium.

In summary, oestrogens and progestogens have major effects on growth and function of the various cell types of the human uterus both in physiological and in pathological conditions. Moreover, the physical and chemical effects induced by steroid hormones are differential for the warious cell types. As interactions between stromal and epithelial cells appear essential for normal growth and function during the menstrual cycle, they may also be involved in the process of steroid hormone-related malignant transformation. Therefore, to obtain more information on the mechanisms involved in endometrial carcinogenesis and tumour behaviour, steroid hormonal. relationships should be preferentially studied at the cellular level.

\subsection{Steroid receptors: structure and function}

In the study of hormonal interactions in the process of neoplastic transformation, knowledge on the mechanism of steroid hormone action is mandatory. In response to physiological levels of oestrogen, uterine target cells produce specific nuclear receptor proteins, a.o. OR and PR $(60,61)$. The OR is a single polypeptide chain of 595 amino acids with a molecular weight of 66 kilodaltons $(\mathrm{kD},\{62\})$. It binds $\mathrm{E}_{2}$ with high affinity $\left(K_{d}=0.1 \mathrm{nM}\right)$, whereas $E_{1}$ and $E_{3}$ display approximately one-tenth of this binding affinity $(29,61)$. The PR is a protein of 933 amino acids with a calculated molecular weight of $98 \mathrm{kD}$ (63). Progesterone binds to the complete receptor with high affinity $\left(K_{d}=1 \mathrm{nM}\right)$, but the resultant complex dissociates rapidly $(61,64)$. A synthetic 19-norprogesterone, $\mathrm{R} 5020$, is useful as a laboratory probe, since it dissociates far more slowly from the PR than progesterone (64).

Molecular cloning of receptor genes and analyses of receptor amino acid sequences have established that steroid receptors, thyroid receptors, and receptors for vitamin D all belong to a single 'superfamily' of gene regulatory proteins $(65,66)$. Even though 


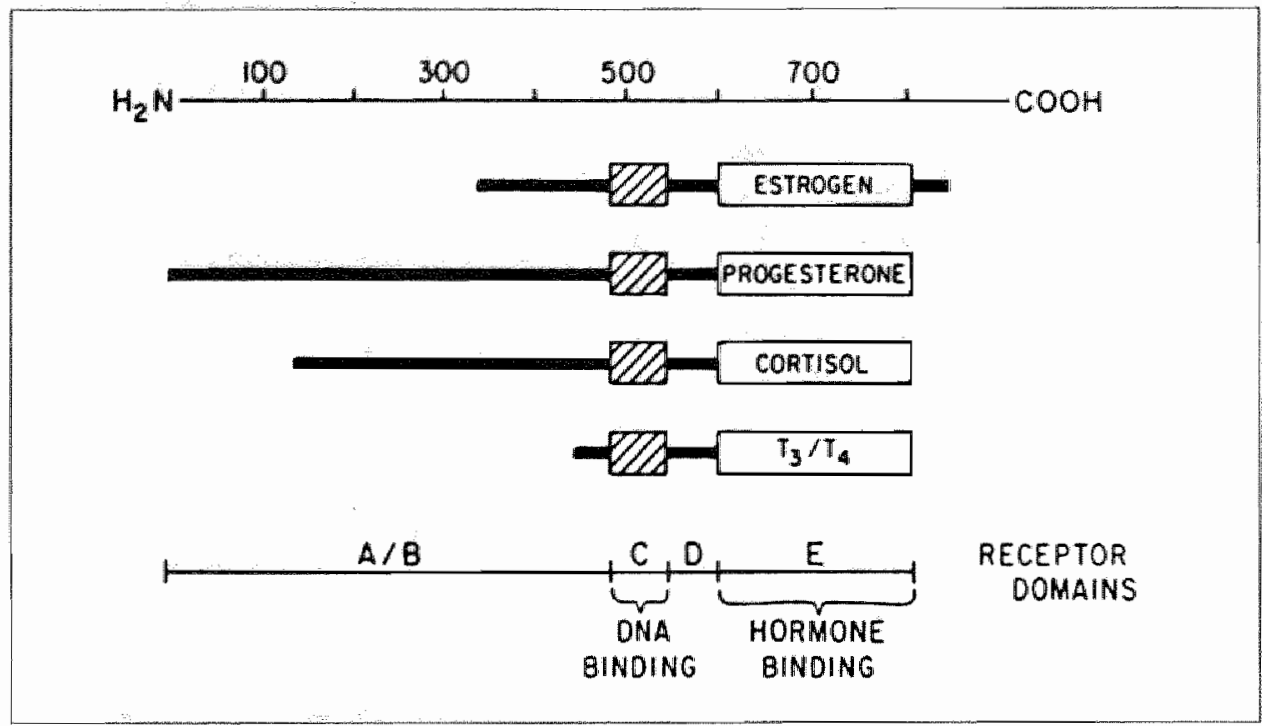

Fig. 1. Schematic comparison of steroid and thyroid $\left(T_{,} T_{4}\right)$ homone receptors' predicted anino acid sequences as deduced from cloning and sequence analysis of appropriate complementary DNA. The steroid receptor can be divided into sit reglons. Region $E$, the homone-binding domain (which lies in the carboxyl portion of the receptor), and particularly region $C$, the DNA-binding domain (approximately 66 amino acid residues with two pairs of cystemes), have a significant structurat homology, and regions $A / B$ (the immunogenic domain) and the hydrophilic region $D$ have lithle or no significant homology. From Leavitt WW (67)

their ligands are different, these receptors appear to act similarly as transcriptional factors in the regulation of many different aspects of cellular growth and differentiation. All these proteins contain several highly conserved domains (Fig $1,\{67\}$ ), with the following functions:

1. specific and high affinity ligand binding

2. specific DNA binding

3. transcriptional modulation.

The mechanism of receptor action is complex (Fig 2, (68)): the unbound oestrogens and progestogens pass through the cell membranes by passive diffusion. Intracellularly, they specifically bind to the receptor protein near the $\mathrm{C}$-terminal region (ad 1.) which is located in the cell nucleus. Subsequent to this high affinity-binding, a change in steroid-receptor complex termed 'activation' or 'transformation' occurs. During this transformation the receptor frees itself from receptor-associated proteins (90 $\mathrm{kD}$-heat shock proteins, thereby increasing the affinity of the complex for nuclear DNA. A highly hydrophylic basic and cysteine-rich region of the receptor is supposed to be important in DNA binding (ad 2.). Specific target genes (acceptor sites) for steroid hormone receptors have been isolated on the DNA and their structure has been defined: steroid response elements (SRE's). These acceptor sites are defined as low-capacity, high-affinity, target tissue-specific domains that 
preferentially bind a single class of steroid hormone receptors. The receptors bind to these SRE's as dimers, with the effect that these genes come under homonal control. Subsequent modulation of transcription of the genes (ad 3.) leads to the production of messenger RNA's which in turn lead to either the synthesis or the inhibition of specific cellular proteins, which express the particular end-points specific for the hormonal effect. E.g. the synthesis of PR is induced by the action of oestrogen; the presence of PR thus implies a 'functional OR' and the concentration of PR is dependent on previous oestrogen action $(34,60,61,67,69)$. In contrast, progesterone lowers or inhibits both the PR ('downregulation') and OR of uterine target cells $(34,41,60,61,64,67,70)$. Although the specific metabolic steps in the mechanism of steroid hormone action are still not entirely clear, it has been established that hormone-induced target cell responses are mediated by the stimulation of protein synthesis. Furthermore, the appearance of steroid-induced proteins is preceded by quantitative as well as qualitative changes in RNA synthesis.

From the foregoing, it evolves that specific steroid receptors are important as signal transducers and transcription factors and there is evidence for a pivotal role in the (patho)physiological changes in and between the different uterine cells. Therefore, steroid receptor determination at the cellular level appears an appropiate way to investigate endocrine mechanisms operative in endometrial (patho)physiology.

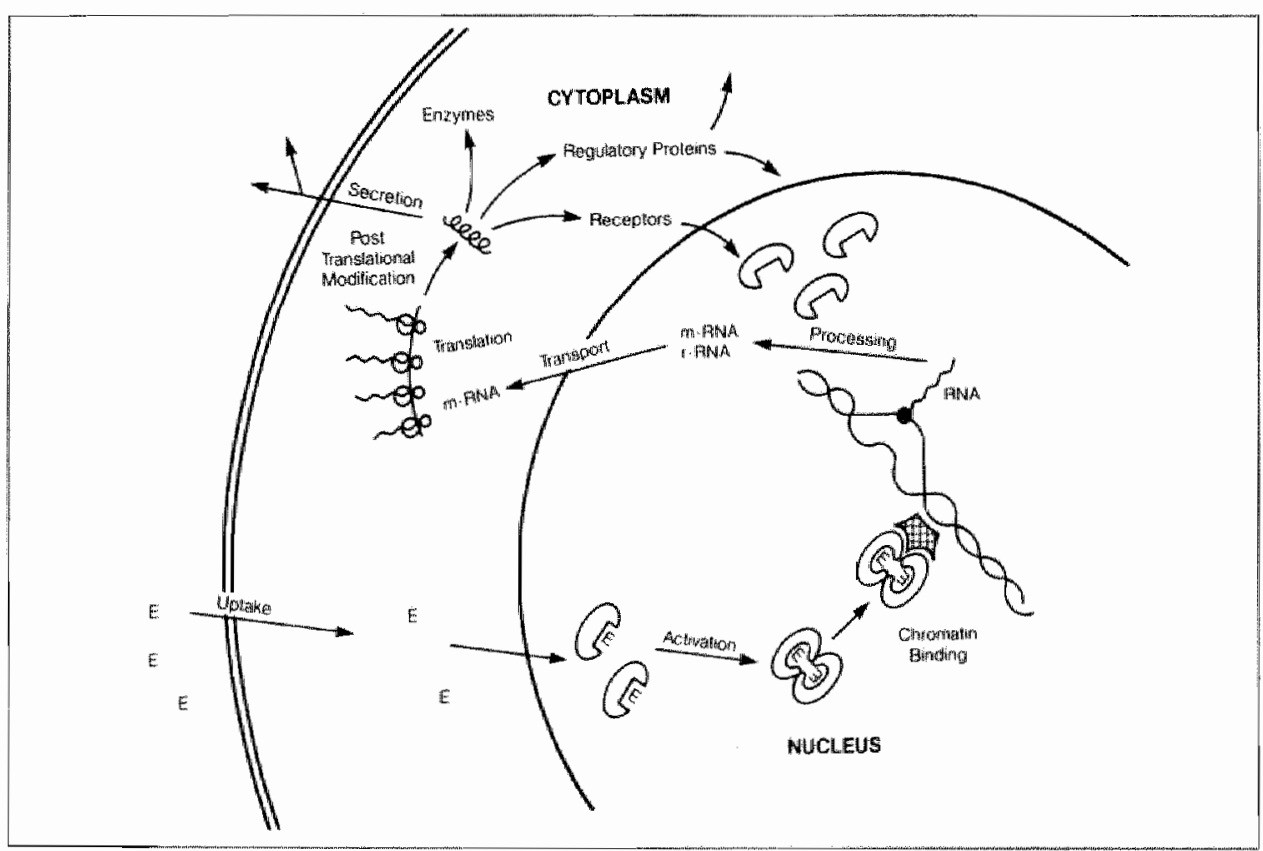

Fig. 2. Schenatic diagram of the interaction pathway of oestrogen (E) with a target cell. Deformed elipsoids: the oestrogen receptor protein. From DeSombre ER \& Kuivanen PC (6\&) 


\subsection{Methods of $O R$ and PR determination}

Two main approaches can be used for the determination of steroid receptors:

1. radioligand binding assay

2. immunocy tochemical assay

\section{ad 1}

The 'classical' method for the quantification of steroid receptor content is the measurement of specific high affinity binding after incubation of a tissue cytosol with radioactive ligands $(71,72)$. However, some drawbacks and technical piffalls may be associated with this radioligand binding assay (73-75). For example, variations in tissue sampling and storage, high intra- and interassay variability, the minimum amount of $200 \mathrm{mg}$ of tissue that is required for reliable receptor determination, and the impossibility to verify the histological composition of heterogeneous tissue specimens are disturbing factors. In general, radioligand binding assays do not provide information about inter- and intracellular distribution of receptors.

To overcome the problems of unknown uterine tissue composition (76-78), radiochemical steroid receptor assay can successfully be performed on tissue sections $(79,80)$. However, although this technique permits control of histomorphology on parallel sections, localization of steroid receptors at cellular level is still not achieved.

\section{ad 2}

Since 1975 many reports have described the attempts of (immuno)histochemical detection of steroids using either anti-steroid antibodies, autofluorescent antibodies, autofluorescent ligands, or directly fluorochromated ligands. However, it has become clear that they can not be used to detect steroid receptors (81). During the last decennium monoclonal antibodies were developed, which have been successfully applied for the immunocytochemical detection of OR and PR in fresh frozen sections of uterine tissue $(82,83)$. The main advantage of the immunocytochemical assay is that it permits visualization of receptors in individual cells and quantification in tissue sections with preservation of bistomorphology. Furthermore, it allows receptor determination in very small tissue samples. However, as semiquantitative evaluation of steroid receptor immunocytochemistry is subjective, inter- and intraobserver variability must be assessed and quality control must be considered $(84,85)$. Computer-assisted image analysis may represent a more accurate means of achieving objective quantification of steroid receptor immunocytochemistry $(86,87)$. 
With respect to $\mathrm{OR}$ and PR-status in endometrial cancer, significant positive correlations have been reported between the results of immunocytochemical receptor staining and radiochemical quantitation (88-90). However, in contrast to breast cancer, reports on direct quantitative correlation are scarce (91). Mortel et al. (76) and Soper et al. $(77,78)$ have emphasized the potential pitfalls of steroid receptor determination in endometrial carcinoma specimens, mentioning tissue and tumour cell heterogeneity. Optimal preservation of histomorphology is an essential prerequisite for reliable interpretation of immunocytochemical steroid receptor staining in tissues, which may contain not only tumour epithelium, but also receptorpositive stroma, hyperplastic epithelium, normal endometrium, and myometrium in one specimen. In this respect, paraffin sections are superior to fresh frozen sections.

\subsection{Results of steroid receptor studies in the human uterus}

\section{Radioligand binding assay on cytosol}

During the normal menstrual cycle, OR and PR levels vary according to the stage of the menstrual cycle (92-94). Radiochemical analyses have revealed that total OR and PR concentrations increase during the proliferative phase to a maximum prior to ovulation. PR concentrations were found higher at the end of the proliferative phase than OR levels. After ovulation, a rapid decrease of total OR was seen in the early secretory phase and a still larger decrease in the late-secretory phase, to concentrations well below those at the beginning of the cycle. The decrease of total PR in the secretory phase was more gradual. During the menstrual cycle the myometrial OR and PR concentrations varied according to the same pattern as for endometrium but at lower levels. A curious finding has been that the tissue receptor content as determined radiochemically, decreased gradually from the fundus to the cervix uteri (95-97).

After menopause, the OR concentration in endometrium and myometrium was comparable to, or lower than that in the early-proliferative phase of the menstrual cycle. Most authors have found absent or very low levels of PR in postmenopausal endometrium or myometrium $(98,99)$.

In endometrial malignancy, the $O R$ concentrations were found to be similar or somewhat lower than in normal proliferative endometrium and in hyperplastic endometrium (100-102). The highest PR levels were found in hyperplastic endometrium, while the levels were lower in adenocarcinoma tissues. In correlating receptor levels with the grade of differentiation of the endometrial carcinoma, most authors reported a higher incidence and content of OR and PR in well-differentiated as compared to poorly-differentiated endometrial tumours $(98,101-108)$. In some studies however, conflicting results have been reported $(100,109-111)$. When 
radiochemical receptor levels were correlated with the depth of myometrial invasion, most authors found significantly lower OR and PR concentrations in deeply invading tumours $(105,106,108)$, except for Creasman et al. $(104,107)$ and Utaaker et al. (111) who found no association.

The prognostic value of the radiochemical receptor status in endometrial cancer is not as clear as in breast cancer (104-107,110-114). Although only one third of patients with advanced or recurrent endometrial cancer responds to endocrine therapy (22), $80 \%$ of patients with well-differentiated endometrial cancer has a positive OR and PR status, but with loss of differentiation this proportion decreases to $40 \%$. Ehrlich et al. (102) found a statistically significant correlation between the presence of specific PR and response to progestogen therapy. However, some authors have reported that prognosis and response to endocrine therapy can not be predicted by radiochemical assay of steroid receptors in endometrial carcinoma (106,111,112). Methodological drawbacks of the applied radiochemical cytosol assay may be largely responsible for the contradictory results and also for the discrepancies between steroid receptor data and clinical results (73-78).

\section{Immunocytochemical analysis}

In 1984, Press and Greene (115) were the first to report an immunocytochemical method for demonstrating OR in frozen sections of human uterus using monoclonal antibodies. Exclusive nuclear localization of OR was found in epithelial, stromal, and smooth muscle cells throughout the reproductive tract in both postmenopausal women and women of reproductive age, as was confirmed by others (116-118). During the menstrual cycle, the epithelial and stromal cells of the endometrium functionalis showed substantial changes in the pattern of staining for OR (119). OR was detected in the nuclei of the vast majority of epithelial and stromal cells in all early, middle, and late proliferative phase endometria. Immunoreactivily remained strong up to the mid secretory phase, when a marked reduction of the staining intensity in the functionalis was noted. Only weak OR staining of stromal and epithelial cells was reported throughout the remainder of the secretory phase. Myometrial smooth muscle cells also contained OR. However, endothelial and smooth muscle cells of uterine vessels showed no staining for receptor. In contrast to results obtained using the radiochemical cytosol assay (95-97), no systematic regional variation in the staining intensity or distribution of stained cells was observed (117).

Postmenopausal endometria consistently showed intense nuclear staining for $O R$ in epithelial and stromal cells.

In 1986, McCarty et al. (120) and Budwit-Novotny et al. (89) reported immunohistochemical analysis of $O R$ in endometrial carcinomas. A weak quantitative correlation was shown between histological receptor score and the radiochemical analysis of OR content in tissue homogenates $(r=0.65)$. It was suggested that the 
admixture of receptors in stromal and myometral elements with those of malignant epithelial elements may yield radiochemical assay results in endometrial carcinoma that do not reflect cancer-cell receptor content. Subsequently, marked tumour cell and tissue OR heterogeneity in endometrial carcinoma specimens was reported by Pertschuk et al. (88) and Thornton and Wells (118). Mutch et al. (121) demonstrated a correlation between OR content and histological grade and tumour stage. All authors agreed that the immunocytochemicall localization of OR (and PR in the near future? $\{83,90\})$ in recognizable tumour cells might better predict the biological behaviour and clinical endocrine response of endometrial malignancy.

\subsection{Aims of the study}

Oestrogens and progestogens strongly effect growth and differentiation of the normal and the aberrant endometrium. We assume that hormonal interaction belween stromal and epithelial cells is not only of crucial importance in the normal endometrium but also in proliferative disorders of the endometrium. Studies on the hormonal interrelationships between the various uterine cell types may yield essential information on the behaviour of endometrial tumours. The OR and PR are pivotal proteins mediating the hormonal modulation of cellular growth and differentiation in the human uterus. Therefore, as immunocytochemistry allows visualization and (semi)quantitation of OR and PR at the cellular level, receptor analysis in normal, hyperplastic, and neoplastic uterine cells may yield relevant knowledge on endometrial physiology and tumour behaviour.

In the present thesis a study is described, which intended firstly to validate the method of steroid receptor immunocytochemistry for uterine tissue samples, secondly to study the pattern of receptor expression in normal and (pre)malignant uterine cells and thirdly to examine the potential value of receptor staining for clinical management of endometrial cancer patients. To this end the following approaches were chosen:

- Tissue and steroid receptor heterogeneity in uterine samples was evaluated using both a radiochemical and immunocytochemical assay on parallel frozen-tissue sections (chapter 2).

- OR and PR immunocytochemistry was optimized for use on routinely-lixed, paraffin-embedded tissue samples, to guarantee optimal preservation of histomorphology. The technique was validated in a quantitative study, comparing results obtained on frozen sections of normal uterine specimens with those on paraffin sections (chapter 3 ).

- OR and PR distribution was analysed in the different phases of the menstrual cycle and after menopause, to obtain more insight into the relation between cyclic and regional changes in steroid receptor expression and function-related changes in the various cell types of the normal human uterus (chapter 4). 
- Immunocytochemical OR and PR expression in stromal and epithlial cells was quantitated with computerized image analysis on paraffin-embedded sections of endometrial hyperplasias, atypical hyperplasias and adenocarcinomas, to determine whether steroid receptor distribution may give indications on the stromal-epithelial relationships in the process of malignant transformation (chapter 5).

- Immunocytochemical OR and PR results were correlated with clinical and histopathological aspects of 169 endometrial cancer patients, to evaluate the relationship between cellular steroid receptor content and established prognostic factors (chapter 6).

- The immunocytochemical OR and PR results were studied in relation to long term survival with univariate as well as multivariate analysis, to evaluate the prognostic relevance of steroid receptor immunocytochemistry (chapter 7).

\subsection{References}

1 Jensen OM, Estève I \& Renard H. Cancer in the European Community and its member states. Eur J Cancer 1990, 26: 1167 - 1256

2 FIGO. Annual report on the results of treatment in gynecological cancer. Vol. 21. Petterson F, ed. Stockholm, Radiumhemmet 1991

3 Kurman RJ \& Norris HJ. Endometrial carcinoma. In: Blaustein's Pathology of the Female Genital Tract, 3rd ed. Kurman RJ, ed. New York, Spinger Verlag 1989: 338 - 373

4 Boltenberg A, Furgyik S \& Kullander S. Familial cancer aggregation in cases of adenocarcinoma corporis uteri. Acta Obstet Gynecol Scand 1990, 69: 249 - 258

5 Disaia PJ \& Creasman WT. Adenocarcinoma of the uterus. In: Clinical Gynecologic Oncology, 3rd ed. Bircher S, ed. St.Louis, CV Mosby 1989: 161 - 198

6 Morrow CP, Bundy BN, Kurman RJ et all. Relationship between surgical-pathological risk factors and outcome in clinical stage $\mathbb{I}$ and II carcinoma of the endometrium: a Gynecologic Oncology Group study. Gyn Oncol 1991, 40: 55 - 65

7 Christopherson WM. The significance of the pathologic findings in endometrial cancer. In: Endometrial Cancer. Clinics in Obstetrics and Gynaecology. London, WB Siunders 1986, 13: $673-695$

8 Aalders JG, Abeler V \& Kolstad P. Recurrent adenocarcinoma of the endometrium. A clinical and pathological study of 379 patients. Gyn Oncol 1984, 17:85-103

9 Hanson MB, van Nagell JR Jr, Powell DE et al. The prognostic significance of lymphvascular space invasion in stage I endometrial cancer. Cancer 1985, 55: 1753 - 1757

10 Putten van der HW, Baak JP, Koenders TJ, Kurver PH, Stolk HG \& Stolte LA. Prognostic value of quantitative pathological features and DNA content in individual patients with stage I endometrial carcinoma. Cancer 1989, 63: 1378 - 1387

11 Sorbe B, Risberg B \& Frankendal B. DNA ploidy, morphometry and nuclear grade as prognostic factors in endometrial carcinoma. Gyn Oncol 1990, 38: 22 - 27 
12 Lucas WE. Causal relationships between endocrine metabolic wariabtes in patients with endometrial carcinoma. Obstet Gynecol Surv 1974, 29:507-528

13 Smith DC, Prentice R, Thompson DJ \& German W. Association of exogenous estrogens and endometrial carcinoma. N Engl J Med 1975, 293: 1164-1167

14 Ziel HK \& Finkle WD. Increased risk of endometrial carcinoma among users of conjugated estrogens. N Engl J Med 1975, 293: 1167 - 1170

15 Siiteri PK. Steroid hormones and endometrial cancer. Cancer Res 1978, 38: $4360-4366$

16 Gambrell RD Jr. The role of hormones in the etiology and prevention of endometrial cancer. In: Endometrial Cancer. Clinics in Obstetrics and Gynecology. London, WB Saunders 1986. 13: $695-725$

17 Persson I, Adami H-O, Bergkvist L et al. Risk of endonetrial cancer after treatment with oestrogens alone or in conjunction with progestogens: results of a prospective study. Br Med J $1989,298: 147-151$

18 Voigt LF, Weiss NS, Chu J, Daling JR, McKnight B \& vanBelle G. Progestagen supplementation of exogenous oestrogens and risk of endometrial cancer. Lancet 1991, 338:274-277

19 Bokhman JV. Two pathogenetic types of endometrial carcinoma. Gyn Oncol 1983, 15: 10- 17

20 Smith MC \& McCartney AJ. Occult, high-risk endometrial cancer. Gyn Oncol 1985, 22: 154-161

21 Ferenczy $\mathbf{A} \&$ Gelfand $M$. The biologic sigmificance of cytologic alypia in progestogentreated endometrial hyperplasia. An J Obstet Gynecol 1989, 160: $126-131$

22 Kauppila A. Progestin therapy of endometrial, breast and ovarian carcinoma. Acta Obstet Gynecol Scand 1984, 63:441-450

23 Judd HL, Davidson BJ, Frumar AM, Shamonki JM, Lagasse LD \& Ballon SC. Serum androgens and estrogens in postmenopausal women with and without endometrial cancer. Am J Obstet Gynecol 1980, 136:859 - 866

24 Davidson $\mathbf{B J}$, Gambone JC, Lagasse $\mathbf{L D}$ et al. Free estradiol in postmenopatusal women with and without endometrial cancer. J Clin Endocrinol Metab 1981, 52: 404 - 408

25 Alsbach GP, Franck ER, Poortman J \& Thijssen JH. Subcellar distribution of estradiol and estrone in human endometrium and myometrium during the menstrual cycle. Contraception 1983, 27: 409-421

26 Vermeullen-Meiners C, Benedek Jaszman LJ, Haspels AA, Poortman J \& Thijssen JH. The endogenous concentration of estradiol and estrone in normal human postmenopasal endometrium. J Steroid Biochen 1984, 21: $607 * 612$

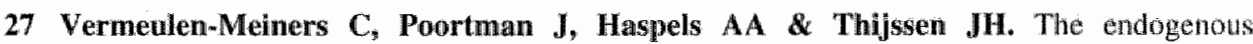
concentration of estradiol and estrone in pathological human postmenopausal endometrium. J Steroid Biochem 1986, 24: $1073-1078$

28 Miller WR O'Neill JS. The significance of steroid metabolism in human cancer. J Steroid Biochem 1990, 37: $317-325$

29 Collins WP. Ovarian steroid hormones. In: Scientific Foundations of Obstetrics and Gynatocology, 3rd ed. Elliot P, Bames I \& Newton M., eds. London, Heinemann Medical Books 1987; $465-472$

30 Ferenczy A, Bertrand G \& Gelfand MM. Proliferation kinetics of human endometrium during the normal menstrual cycle. Am J Obstet Gynecol 1979, 133:859-867

31 Key TJA \& Pike MC. The dose-effect relationship between "unopposed" oestrogens and endometrial mitotic rate: its central role in explaining and predicting endometrial cancer risk. Br J Cancer 1988, 57:205 - 212 
32 Thornton $\sqrt{G}$, Quirke $P$ Wells $M$. Flow cytometry of normal, hyperplastic, and malignant human endometrium. A study of ploidy and proliferative indices induding comparison with in vitro S-phase labeling. Am I Obstet Gynecol 1989, 161: $487-492$

33 Roberts DK, Walker $\mathrm{NJ}$ \& Lavia LA. Ultrastructrurall evidence of stromallepithelial interactions in the human endometrial cycle. Am J Obstet Gynecol 1988. 158:854 - 861

34 Healy DL Hodgen GD. The endocrinology of human endometrium. Obstet Gynecol Surv 1983, $38: 509-530$

35 Smith SK. Prostaglandins and growth factors in the endometrium. Bailiere"s Clinical Obstetrics and Gyndecology $1989,3: 249-271$

36 Nurphy $L_{\text {I }}$ \& Ghahary $A$. Uterine insulin-like growth factor-I: regulation of expression and its role in estrogen-induced uterine proliferation. Endocr Rev 1990, 11:443-452

37 Bonaceorsi $G$, Pansini $F$, Segala $V$, Bagni B, Bergamini CM \& Mollica $G$. Modification of number and of affinity of endometrial EGF receptors during the menstrual cycle. Eur J Obstet Gynecol Reprod Biol 1989, $33: 177-182$

38 Odlon LD, Barret $\mathrm{M}_{\text {, Pantakis }} \mathrm{CG}_{\text {, }}$ Stoddard LD \& McDonough PG. Immunocytochemical study of ras and myc proto-oncogene polypeptide in the human menstrual cycle. An J Obstet Gynecol 1989, 161:1663-1668

39 Gelfand MM \& Ferenczy A. A prospective I-year study of estrogen and progestin in postmenopatsal women: effects on the endometrium. Obstet Gynecol 1989, 74:398-402

40 Parazzini F, La Vecchia C, Bocciolone L Franceschi S. Review. The epidemiology of endometrial cancer. Gyn Oncol 1991, 41: 1-16

41 Clarke CL \& Sutherland RL. Progestin regulation of cellular proliferation. Endocr Rew $1990,11: 266-301$

42 Tseng L, Mazela J \& Sun B. Modulation of aromatase activity in human endonetrial stromal cells by steroids, tamoxifen and RU 486. Endocrinol 1986, 118:1312 - 1318

43 Randolph JF, Peegel H, Ansbacher R \& Menon KM. In vitro induction of prolactin production and aromatase activity by gonadal steroids exclusively in the stroma of separated proliferative human endometrium. Am J Obstet Gynecol 1990, 162: 1109-1114

44 Satyaswaroop PG, Wartell DJ \& Mortel $\mathbf{R}$. Distribution of progesterone receptor, estradiol dehydrogenase, and $20 \alpha$-dihydroprogesterone dehydrogenase activities in human endometrial glands sund stroma: progestin induction of steroid dehydrogenase activities in vitro is restricted to the glandular epithelium. Endocrinol 1982, 11:1: 743-749

45 Parmley Th, Roberts DK, Walker NJ \& Horbelt DV. Intercellalar contacts between stronal cells in the normal endometrium throughout the menstrual cycle. Hum Path 1990, 21: $1063-1066$

46. Buletii $\mathrm{C}$, Calassi $\mathrm{A}$, Jasonni VM, Martinei $\mathrm{G}$, Tabanei $\mathrm{S} \&$ Flanigni $\mathrm{C}$. Basement membrane components in normal, hyperplastic and neoplastic endometrium. Cancer 1988, 62: $142-149$

47 Shah DM, Higuchi K, Inagani T \& Osteen KG. Effect of progesterone on renin secretion in endometrial stromal, chorionic trophoblast, and mesenchymal monolayer cultures. Am „J Obstet Gynecol 1991, 164: \145-1150

48 Bell SC. Decidualization and insulin-like growth factor (IGF) binding protein: implications for its role in stromal cell differentation and the decidusl cell in haemochorial placentation. Hum Reprod 1989, 4: 125-130

49 Waites GT, Wood PL, Walker RA \& Bell SC. Immunohistological localization of human endometrial secretory protein 'pregnancy-associated endometrial $\alpha_{2}$-globulin' $\left(\alpha_{2}-\mathrm{PEC}\right)$, during the menstrual cycle. J Reprod Fert 1988, 82: $665-672$ 
50 Alecozay AA, Cassien BG, RiehI RM et al. Platelet-activating factor in human luteal phase endometrium. Biol Reprod 1989, 41:578-586

51 Reynolds RK, Taavera F, Roberts JA, Hoplkins MP \& Menon KM Regulation of epidemal growth factor and insulin-like growth factor I receptors by estradiol and progesterone in normal and neoplastic endometrial cell cultures. Gyn Oncol 1990, 38: 396 - 406

52 Parmley $\mathbf{T}$. Embryology of the female genital tract. In: Blaustein 's Pathology of the Female Genital Tract, 3rd ed. Kurman RJ, ed. New York, Springer Verlag 1989:1 - 15.

53 Kratchowil K. The stroma and the control of cell growth. J Pathol 1986, 149:23-24

54 Cunha GR, Bigsby RM, Cooke PS \& Sugimura Y. Rewiew. Stromal-epithelial interactions in adult organs. Cell Diff $1985,17: 137-148$

55 Cunha GR, Chung LW, Shamon JM, Taguchii O \& Fujii H. Hormone-induced morphogenesis and growth: role of mesenchymal-epithelial interactions. Ree Prog Horm Res $1983,39: 559-598$

56 Cooke PS, Uchima F-DA, Fujii DK, Bern HA \& Cunha GR. Restoration of nonmal morphology and estrogen responsiveness in cultured vaginal and uterine epithelia-transplanted with stroma. Proc Natl Acad Sci USA 1986, 83:2109-2113

57 Bigsby RM \& Cunha GR. Estrogen stimulation of deoxyribonucleic acid synthesis in uterine epithelial cells which lack estrogen receptors. Endocrinol 1986, 119:390-396

58 Ylikomi T \& Tuohimaa P. Sex-steroid-sensitive stromal cells and oviduct differentiation J Steroid Biochem 1988, 30:472 - 476

59 Cunha GR, Young $\mathbf{P} \&$ Brody JR. Role of thterine epithelium in the development of myometrial smooth muscle cells. Biol Reprod 1989.40:861-871

60 McCarty KS Jr, Lubahn DB \& McCarty KS Sr. Oestrogen and progesterone receptors: physiological and pathological considerations. J Clin Endocrinol Metab 1983,12 : $133-154$

61 Speroff L, Glass RH \& Kase NG. Hormone biosynthesis, metabolism, and mechanism of action. In: Clinical Gynecologic Endocrinology and Infertility, 4th ed. Brown C-L, ed. Baltimore, Williams \& Wilkins 1989: 1- 51

62. Green $S$, Walter $P$, Kumar $V$ et al. Human oestrogen receptor cDNA: sequence, expression and homology to v-erb-A. Nature 1986, 320: 134 - 139

63 Misrahi $\mathrm{M}_{*}$ Atger $\mathrm{M}$, d'Auriol $\mathrm{L}$ et al. Complete amino acid sequence of the thuman progesterone receptor deduced from cloned cDNA. Biochen Biophys Res Comm 1987, 143: $740-748$

64 McGuire WL, Raynaud J-P \& Baulieu E-E, eds. Progesterone receptors in nortnkl and neoplastic tissues. Progess in Cancer Research and Therepy. New York, Raven Press 1977, 4

65 Evans RM. The steroid and thyroid hormone receptor superfamily. Science 1988, 240: 889 . 895

66 Carson-Jurica MA, Schrader WT \& O'Malley BW. Steroid receptor family: structure and functions. Endocr Rev 1990, 11:201-220

67 Leavitt WW. Cell biology of endometrim. In: Biology of the Human Uterus, 2nd ed. Wynn RM \& Jollie WP, eds. New York, Plenum 1989:131 1.75

68 DeSombre ER \& Kuivanen PC. Progestin modukation of estrogen-dependent marker protein synthesis in the endometrium. Sem Oncol 1985, 12 (suppl. 1): 6-11

69 Jänne O, Kontula K, Lunkkainen T \& Vihko R. Oestrogen-induced progesterone receptor in human uterus. J Steroid Biochen 1975, 6: 501 - 509 
70 Hsweh A., Perk EJ Clark. JH. Progesterone antagonism of the oestrogen receptor and oestrogen-indued uterine growth. Nature 1975, 254: $337-339$

71 Baxter JD \& Funder JW. Homone receptors. N Engl J Med 1979, 301: $1149-1161$

72 Smith RO \& Sestill MA. Methods for ligand receptor assays in clinical chemistry. Clin Chem $1980,26: 543-550$

73 Ledercq G. Technical pittalls, methodological improwements and quality control of steroid hormone receptor assays. Eur I Cancer Clin Oncol 1987, 23:453-458

74 Borjesson BW, Cauchi MN, Compton PJ et al. Identification of the major sources of error in estrogen receptor measurements for individual laboratories using both tissue and cytosol samples. Eur J Cancer Clin Oncol 1989, 25: 1079-1086

75 Parl FT \& Posey YF. Discrepancies of the biochemical and immunohistochemical estrogen receptor assays in breast cancer. Hum Pathol 1988, 19:960-966

76 Mortel R, Zaino R \& Satyaswaroop PG. Heterogeneity and progesterone-receptor distribution in endometrial carcinoma. Cancer 1984,53:113-116

77 Soper JT, McCarty KS Jr, Creasman WT \& McCarty KS Sr. Histologic control of biochemical steroid receptor analysis in endometrial carcinomas. Am J Obstet Gynecol 1985, $153: 520-523$.

78 Soper JT, Cox EB, Budwit-Novotny D et al. Histologic composition of endometrial carcinomas analyzed for steroid receptor content. Am J Obstet Gynecol 1987, 157: 26 - 27

79 De Goej AF, Volleberg MP, Hondius GG \& Bosman FT. Radiochemical determination of estrogen receptors in cryostat sections of target tissues. J Steroid Biochem 1984, 2 l: $127-134$

80 De Goeij AF, Scheres HM, Rousch MJ, Hondïus GG \& Bosman FT. Progesterone receptor quantification with radiolabeled promegestone ( $R 5020$ ) in frozen sections of endometrium and breast cancer tissue. J Steroid Biochem 1988, 29:465-474

81 De Goeij AF, Bosman FT \& Berns EM. Invited Review. Determination of steroid hormonedependency of tumours utilizing tissue sections. Survey of histochemical techniques and their application in surgical pathology.J Pathol 1986, 149: 163- 172

82 King WJ \& Greene GL. Monoclonal antibodies localize estrogen receptor in the nuclei of target cells. Nature 1984, 307: 745 - 747

83 Perrot-Applanat M, Logeat F, Groyer-Picard MT \& Milgrom E. Immunocytochemical study of mammalian progesterone receptor using monoclonal antibodies. Endocrinol 1985. 116: $1473-1483$

84 Scheres HME, De Goelj AF, Rousch MJ et al. Estrogen receptor quantiftcation in human breast cancer: radiochemical assay on cytosol and cryostat sections compared with semiquantitative immunocytochemical analysis. J Clin Pathol 1988, 41:623-632

85 Bosman FT, De Goej AF \& Rousch $\mathbf{M J}_{\mathbf{J}}$. Quality control in immunocytochemistry: experiences with the estrogen receptor assay. J Clin Pathol 1992,45:120-124

86 Bacus S, Flowers JL, Press MF, Bacus J \& McCarty KS Jr. The evaluation of estrogen receptor in primary breast carcinoma by computer-assisted image anallysis. Am J Clin Pathol $1988,90: 233-239$

87 Charpin C, Jacquemier J, Andrac L et al. Multiparametric analysis (SAMBA 200) of the progesterone receptor immunocytochemical assay in nonmalignant and malignant breast disorders. Am J Pathol 1988, 132: 199-211

88 Pertschuk LP, Beddoe AM, Gorelíc LS \& Shain SA. Immunocytochemical assay of estrogen receptors in endometrial carcinoma with monoclonal antibodies. Comparison with biochemical assay. Cancer 1986, 57: $1000-1004$ 
89 Budwil-Novotny DA, McCarty KS, Cox EB et al. Immunohistochemical analyses of estrogen receptor in endometrial carcinoma using a monoclonal antibody. Cancer Res 1986. $46: 5419-5425$

90 Zaino RJ, Clarke CL, Mortel R \& Satyaswaroop PG. Heterogeneity of progesterone receptor distribution in human endometrial adenocarcinona. Cancer Res 1988, 48: 1889-1895

91 Soper IT, Segreti EM, Novotny DA, Mutch D, Creasman WT \& MeCarty KS Ir. Estrogen and progesterone receptor content of endometrial carcinomas: comparison of tofat tissue versus cancer component analysis. Gyn Oncol 1990, 36:363-368

92 Levy C, Robel P, Gautray JP et al. Estradiol and progesterone receptors in human endometrium: normal and abnormal menstrual cycles and early pregnancy. Am I Obstet Gynecol 1980, 136:646-651

93 Godoreski IG, Geier A, Lunenfeld B, Betry R \& Bahary CM. Progesterone receptor Jevels and distribution in different phases of the menstrual cycle and in estrogen-primed postmenopausal endometrium. Obstet Gynecol 1986, 68:513-516

94 Tamaya T, Murakami T \& Okada H. Concentrations of steroid receptors in nomal human endometrium in relation to the day of the menstrual cycle. Acta Obster Gynecol Scand 1986. 65: $195-198$

95 Tsibris JC, Fort FL, Caxenave CR et al. The uneven distribution of estrogen and progesterone receptors in human endometrium. J Steroid Biochem 1981, 14:997-1003

96 Godoreski IG, Bahary CM, Lunenfeld B, Beery R \& Geier A. Distribution of total estradiol receptor levels in various segments and tissues of the normal and pathological human uterus. Gynecol Obstet Invest 1988, 26: 296-301

97 Vollmer G, Kniewe M, Meyn U, Tuchel L, Arnholdt H \& Knuppen R. Spatial and molecular aspects of estrogen and progesterone receptor expression in human uteri and viterine carcinomas. J Steroid Biochem 1990, 36:43-55

98 Martin PM, Roland PH, Gammere M, Serment H \& Toga M. Estradiol and progesterone receptors in normal and neoplastic endometrium: contations between receptors, histopathological examinations and clinical responses under progestin therapy. Int $J$ Cancer $1979,23: 321-329$

99 Eiletz J, Genz T, Pollow K \& Schmidt-Gollwitzer M. Sex steroüd levels in serum, myometrium, and fibromyomata in correlation with cytoplasmic receptors and 17 B-HSD activity in different age groups and phases of the menstrual cycle. Arch Gynecol 1980, 229: $13-28$

100 Rodriquez J, Sen KK, Seski JC, Menon M, Johnson TR \& Menon KM. Progesterone binding by human endometrial tissue during the proliferative and secretory phases of the menstraal cycle and by hyperplastic and carcinomatous endometrium. An J Obstet Gynecol $1979,133: 660-665$

101 Vihko R, Jänne $O \&$ Kauppila A. Steroid receptors in normal, hyperplastic, and malignant human endometria. Ann Clin Res 1980, 12: 208 - 215

102 Ehrlich CE, Young PG \& Cleary RE. Cytoplasnic progesterone and estradiol receptor in normal, hyperplastic, and carcinomatous endometria: therapeutic implications. Am J Obstet Gynecol 1981, 141:539-546

103 McCarty KS Jr, Barton TK, Fetter BF", Creasman WT \& McCarty KS Sr. Correlation of estrogen and progesterone receptors with histologic differentiation in endometrial adenocarcinoma. Am J Pathol 1979, 96:171-184

104 Creasman WT, McCarty KS Sr, Barton TK \& McCarty KS Jr. Clinical correlates of estrogen and progesterone binding proteins in human endometrial carcinoma. Obstet Gynecol $1980,55: 363-370$ 
105 Kapppila A, Kujansum $E$ Vihko $R_{*}$ Cytosol estrogen and progestin receptors in endometrial carcinoma of patients treated with surgery, radiotherapy, and progestin. Clinical correlates. Cancer $1982,50: 2157-2162$

106 Quinn MA, Cauchi M Fortune D. Endometrial carcinona: steroid receptors and response to medroxyprogesterone acetate. Gyn Oncol $1985,21: 314-319$

107 Creasman WT, Soper JT, MeCarty KS Jr, McCarty KS Sr, Hinshaw W \& ClarkePearson $\mathrm{D}$. Influence of cytoplasmic steroid receptor content on prognosis of early stage endontrial carcinoma. An J Obstet Gymecol 1985, 151: $922-932$

108 Qumin MA, Pearee P, Cortune DW, Koh SK, Hsieh C \& Canchi M. Correlation between cytoplasmic steroid receptors and tumour differentiation and invasion in endometrial carcinoma. Br J Obstet Gynaecol 1985, 92:399-406

109 Hunter RE, Longcope C \& Jordan VC. Steroid hormone receptors in adenocarcinoma of the endometrium. Gyn Oncol 1980, 10: 1.52-161

110 Martin JD, Hahnel R, McCartney AJ \& Woodings TL. The effect of estrogen receptor status on survival in patients with endometrial cancer. Am J Obstet Gynecol 1983, 147:322324 .

111 Utaaker $\mathbf{E}$, Iversen OE \& Skaarland E. The distribution and prognostic implications of steroid receptors in endometrial carcinomas. Gyn Oncol 1987, 28: 89 - 100

112 Lindahi B, Alm P, Fernö M, Grundsell H, Norgren A \& Tropé C. Relapse of endometrial carcinoma related to steroid receptor concentration, staging, histological grading and myometrial invasion. Anticancer Res 1986, 6: $1317-1320$

113 Castagnetta L, Lo Casto M, Granata OM, Calabro M, Ciaccio M \& Leake RE. Soluble and nuclear oestrogen receptor status of advanced endometrial cancer in relation to subsequent clinical prognosis. Br J Cancer 1987, 55: 543-546

114 Kauppila A. Oestrogen and progestin receptors as prognostic indicators in endometrial cancer. Acta Oncol 1989, 28:561-566

115 Press MF \& Greene GL. Methods in laboratory investigation. An immunocytochemical method for demonstating estrogen receptor in human uterus using monoclonal antibodies to human estrophilin. Lab Invest 1984, 50: $480-486$

116 Charpin C, Martin PM, Lavaut MN, Poturreau-Schneider N \& Toga M. Estrogen receptor immunocytochemical assay (ER-ICA) in human endometrium. Int J Gynecol Pathol $1986,5: 119-131$

117 Press MF, Nousek-GoebI NA, Bur M \& Greene GL. Estrogen receptor localization in the female genital tract. An J Pathol 1986, 123:280-292

118 Thornton JG \& Wells M. Oestrogen receptor in glands and stroma of normal and neoplastic endometrium: a combined biochemical, immunohistochemical, and morphometric study. JClin Pathol 1987, 40: 1437-1.444

119 Press MF, Nousek-Goebl N, King WJ, Herbst AL \& Greene GI. Immunohistochenical assessment of estrogen receptor distribution in the human endometrium throughout the menstrual cycle Lab Invest 1984, 51: $495-503$

120 MoCarty KS Jr, Szabo E, Flowers JL et al. Use of a monocional anti-estrogen receptor antibody in the immunohistochemical evaluation of human tumors. Cancer Res 1986, 46 (suppl): $4244-4248$

121 Mutch DG, Soper JT, Budwit-Novotuy DA et al. Endometrial adenocarcinoma estrogen receptor content: association of clinicopathologic features with immunohistochemical analysis compared with standard biochemical methods. An J Obstet Gynecol 1987, 157: 924 - 931 


\section{CHAPTER 2}

\section{Is immunohistochemical analysis of oestrogen and progesterone receptors in endometrial carcinoma superior to the radioligand binding assay?"}

* Snijders MP, De Goeij AF, Koudstaal Joh, Rousch MJ, Scheres HM, Stoot JE \& Bosman FT. Joumal of Pathology 1990, 161: 129-135 


\section{Summary}

The aim of this study was to evaluate tissue and steroid receptor heterogeneity in endometrial carcinoma specimens as a possible source of discordance between biochemically assayed receptor status and response to endocrine treatment. For this purpose the oestrogen receptor (OR) and the progesterone receptor (PR) levels in specimens from 16 endometrial carcinoma patients were analysed on adjacent tissue sections using both a radiochemical and an immunohistochemical assay. With immunohistochemical receptor analysis extensive tissue and tumour cell heterogeneity was observed. Many tumour samples revealed up to $75 \%$ contamination with benign tissue. In the majority of cases, evaluation of immunoreactivity in normal tissue elements of the specimen could explain the apparent discordance between semiquantitative immunohistochemical receptor scoring of tumour cells and radiochemical receptor assay. Immunohistochemical analysis of $\mathrm{OR}$ and $\mathrm{PR}$ in endometrial carcinoma specimens allows a more specific determination of tumour cell receptor content and hence may yield a more accurate prediction of response to endocrine therapy than the biochemical assay.

\section{Introduction}

Steroid hormone receptor analysis has appeared to be valuable in guiding the therapy for primary and metastatic breast cancer (1). The importance of the steroid receptor status of the tumour for the clinical management of gynaecological neoplasms is less evident. Many clinicians treat patients with advanced or recurrent forms of endometrial cancer and also patients with limited primary carcinomas with 'adjuvant' high-dose progestogen therapy $(2,3)$. Some reports have seriously questioned the supposed beneficial effect of this approach, which is not entirely harmless, on tumour growth in unselected groups of patients $(4,5)$. Better selection criteria for patients at high risk for recurrent disease are needed. The oestrogen receptor (OR) and progesterone receptor (PR) content in endometrial carcinoma may give indications for prognosis and response to hormonal therapy (6-8). However, the response to progestogen therapy is not always accurately predicted by the biochemically assayed receptor status of the tumour $(9,10)$.

The basis of this discrepancy may be found in the heterogeneous character of tissue samples from endometrial carcinoma. Endometrial biopsies may contain areas of hyperplastic endometrium, myometrium, and endometrial stroma adjacent to areas of carcinoma (11). Also, the receptor content of the carcinoma cells might be heterogeneous $(10,12)$. Therefore, receptor localization in carcinoma cells is essential to study adequately the relation between receptor content and tumour response to endocrine treatment. 
Recently, monoclonal antibodies specific for the non-steroid binding moieties of the $\mathrm{OR}$ and $\mathrm{PR}$ have become available. Immunohistochemistry with these monoclonal antibodies allows localization of the steroid receptor at the cellular level $(13,14)$. In the present study, tissue heterogeneity was analysed as a possible source of discordance between biochemical receptor analysis and clinical results. To this end, the receptor content of endometrial carcinoma samples was analysed by immunohistochemistry and a radioligand binding assay was performed on parallel tissue sections (15-17).

\section{Materials and methods}

Tissue specimens were obtained from 16 patients with endometrial carcinoma, surgically treated (at De Wever Hospital, Heerlen) by total abdominal hysterectomy and bilateral salpingo-oophorectomy. The patients ranged in age from 37 to 78 years (mean 61 years) and all but one patients were postmenopausal.

The uterus was opened immediately after hysterectomy and two tumour tissue samples (diameter $1-2 \mathrm{~cm}$ ) were taken from different sites. One block was used for routine histopathological examination and the other for radiochemical and immunohistochemical receptor assay on cryostat sections. These samples were frozen in isopentane cooled with dry ice and stored at $-70^{\circ} \mathrm{C}$. Tumour type and grade were classified by two pathologists on paraffin sections using the International Federation of Gynecology and Obstetrics (FIGO) criteria.

\section{Radiochemical receptor assay on frozen sections}

Frozen sections were cut a $6 \mu \mathrm{m}$ and mounted om gelatin chrome alum-coated coverslips and dried to result in $0.5-1.5 \mathrm{mg}$ of tissue corresponding to roughly 50 $150 \mu \mathrm{g}$ of total tissue protein. A corresponding amount of tissue was stored unmounted in a glass tube $\left(-20^{\circ} \mathrm{C}\right)$ for protein assay, which was performed according to the method of Bradford (1.8). The sections were overlayed with $150 \mu \mathrm{l}$ of EORTC buffer, containing either tritium-labelled oestradiol or R5020 (promegestone, a synthetic PR ligand) at a concentration ranging from 0.25 to $4 \mathrm{nM}(16,17)$. Nonspecific binding was assessed by adding a hundred-fold excess of unlabelled ligand. All incubations were performed in duplicate. Leakage of soluble receptor from the tissue into the overlaying buffer was determined with a dextran-coated charcoal assay. After washing the sections with EORTC buffer, the section-bound receptor was measured by direct liquid scintillation counting. The total tissue receptor content was defined as the sum of soluble and section-bound receptor and expressed as $\mathrm{fmol} / \mathrm{mg}$ total tissue protein. 


\section{Immunohïstochemical receptor analysis}

An anti-OR monoclonal antibody with well-characterized specificity from Abbott Laboratories (Diagnostic Division, The Netherlands) was used. Immunoperoxidase (PAP) staining was performed on sections fixed in picric acid/paraformaldehyde (10 min, $4^{\circ} \mathrm{C}$ ). The primary antibody was used at a dilution of $1: 4$, as reported previously (16). Other procedures were performed according to the manufacturer's instructions.

PR immunohistochemistry was performed using a mouse monoclonal anti-rabbit PR antibody (Transbio, France) which strongly crossreacts with human PR (14). Cryostat sections were fixed in picric acid/paraformaldehyde $\left(10 \mathrm{~min}, 4^{\circ} \mathrm{C}\right)$, rinsed twice in phosphate-buffered saline (PBS) for $5 \mathrm{~min}$, incubated in normal sheep serum (diluted 1.5 in $1 \%$ bovine serum albumin [BSA]/PBS) for $15 \mathrm{~min}$, and incubated overnight at $4^{\circ} \mathrm{C}$ with mouse anti-PR antibody (diluted 1:800 in 1\% BSA/ PBS). After washing ( $2 \times 5 \mathrm{~min}$ in PBS), the sections were incubated (60 min at room temperature) with biotinylated sheep anti-mouse immunoglobulin (Amersham International, U.K.), washed ( $2 \times 5 \mathrm{~min}$ in PBS), and incubated (60 min) with avidin biotin (peroxidase) complex (Vector Laboratories, U.S.A.). After a final wash, the sections were incubated $(7 \mathrm{~min})$ in diaminobenzidine with $0.002 \%$ hydrogen peroxide and $1 \mathrm{nM}$ imidazol (Sigma Chemical, U.S.A.) in PBS.

As a negative control, adjacent sections were reacted with normal rat $\operatorname{IgG}$ instead of anti-OR antibody or a mouse monoclonal antibody directed against an antigen (bromodeoxyuridine) not related to PR instead of anti-PR antibody (19). Sections of a virginal (non-ovulating) rabbit uterine horn served as a positive control.

The sections were stained with Harris' haematoxylin and mounted in Entellan (Merck, Germany).

\section{Scoring of assays}

The receptor content in the radiochemical section assay was calculated in fmol per $\mathrm{mg}$ total tissue protein (15-17). The immunohistochemical receptor staining was scored semiquantitativelly, as published previously (16), using a modification of the approach of McCarty et all. (20).

The immunohistochemical score was calculated as:

$$
\text { receptor score }=\sum_{i=0}^{i=4} \mathrm{P}(\mathrm{i}) \mathrm{xi}
$$

where $i$ is the intensity of staining ranging from 0 (which is no staining) to 4 (which is very intense staining) and $\mathrm{P}(\mathrm{i})$ is the percentage of stained tumour cells in category $\mathrm{i}(0-100 \%)$, assessed on at least three separate cohorts of 100 tumour cells in different high-power ( $x$ 400) fields. Scoring was performed by two independent observers without prior knowledge of the radiochemically determined receptor content, and the receptor scores were calculated as the mean of both independent 
scores. A receptor score $\geq 35$ was considered positive, based on earlier correlative studies (16).

The percentage of the area in the section which is occupied by tumour cells was appraised by the two observers and categorized as more than $75 \%, 50-75 \%$ or $25-50 \%$.

\section{Results}

\section{Radiochemical detection of receptors in cryostat sections}

Specific binding of radiolabelled oestradiol and promegestone (R5020) to frozen sections of an endometrial cancer specimen is shown in Fig. 1. These Scatchard plots show the presence of OR and PR, characterized by saturable and high affinity binding of oestradiol and R5020. The dissociation constants $\left(K_{d}\right)$ are in the 0.2-0.3 nM range.

\section{Receptor immunohistochemistry}

In the human endometrial carcinoma samples, exclusive nuclear localization of specific staining was observed in stromal and myometrial cells as well as in normal and neoplastic epithelial cells. Negative controls of immunostaining did not show any nuclear staining. Marked heterogeneity of the steroid receptor content was frequently observed in the different tissue types and between individual tumour cells

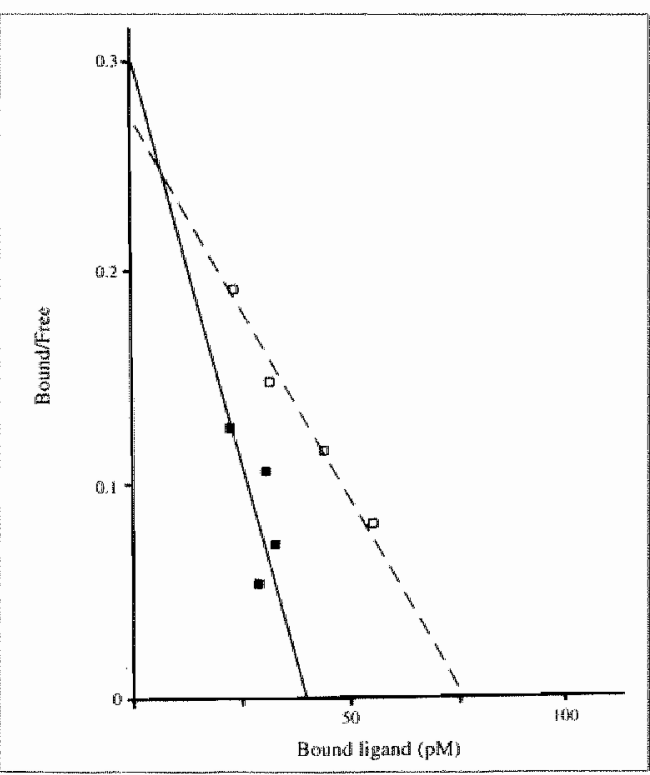

Fig. I. Scatchard analysis of radiochemical $O R$ and PR assay on cryostat sections of endometrial cancer sample. ( $\mathbf{D}$ Total $(=$ soluble and section-bound) $O R$. (口- D) Total $(=$ soluble and sectionbound) $P R$

$O R: B_{\text {ertiti }}=40.3 \mathrm{pM} . K_{d i}=0.2 \mathrm{nM}$. $P R: B_{s \text { stax }}=76.1 p M, K_{d s}=0.3 n M$ 


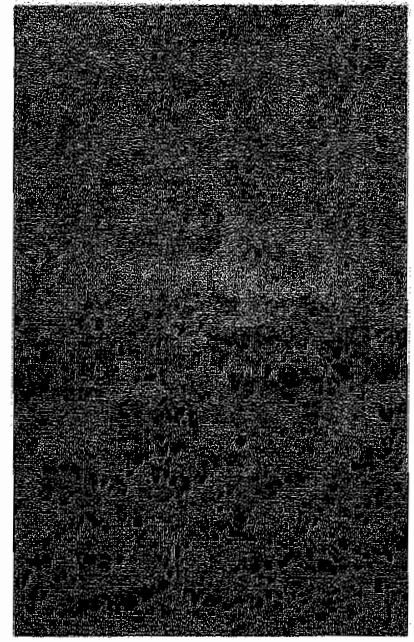

Fig. 2. Human endonetrial carcinoma specimens." heterogeneity of nuclear oR inwunostaining in neoplastic glands

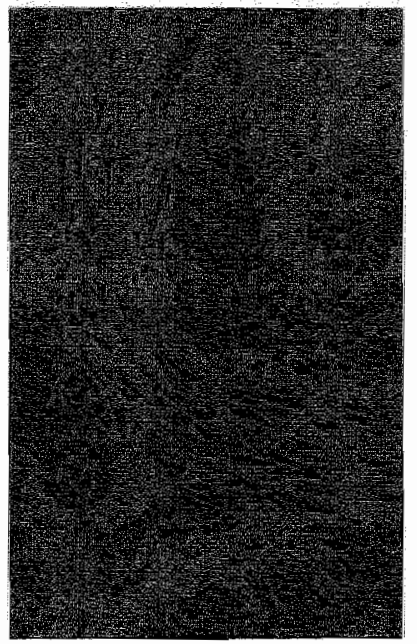

OR staining in smooth muscle cells but absent in adjacent (grade III) rumour cells

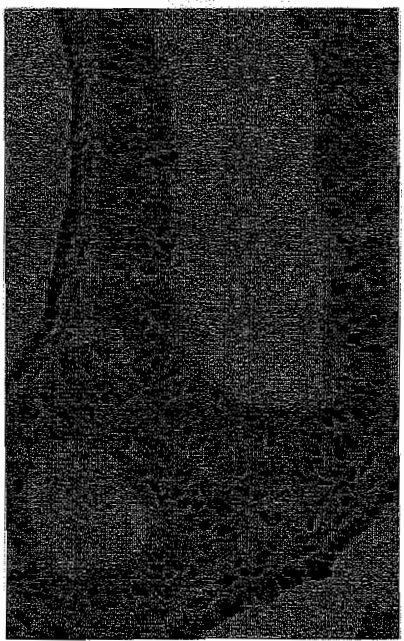

Hyperplastic glandular cells show intense PR inmonoreactivity whereas malignant glands are moderately stained

(Fig. 2a). Receptor staining in stromal and myometrial cells tended to be more homogeneous. Tumour cells close to receptor positive myometrium or stroma often showed intense immunoreactivity. Tumour cells adjacent to the uterine cavity usually showed little or no staining. In many specimens, normal or hyperplastic tissue elements were clearly positive, whereas carcinoma cells displayed no or moderate receptor staining (Figs. $2 \mathrm{~b}$ and $2 \mathrm{c}$ ).

Interobserver variability in the semiquantitative $O R$ and $P R$ score for 16 endometrial cancer specimens is presented in Fig. 3. The results show a significant linear correlation (for OR score: $r=0.84, P<0.0001$; for $P R$ score: $r=0.93, P<0.00001$ ). Analysis of variance indicates that with increasing tumour grade the $O R$ content tends to decrease $(\mathrm{P}=0.01$ for $\mathrm{OR} ; \mathrm{P}=0.5$ for $\mathrm{PR})$.

\section{Comparison between radiochemical and histochemical receptor analysis}

The results of the immunohistochemical receptor scoring and the radioligand binding assay on parallel frozen sections are presented in Table 1. For each specimen, the relative contribution of tumour tissue to the section was determined and categorized as more than $75 \%, 50-75 \%$, or $25-50 \%$. Because normal tissue elements of the corpus uteri may contribute to the receptor content of the tissue 

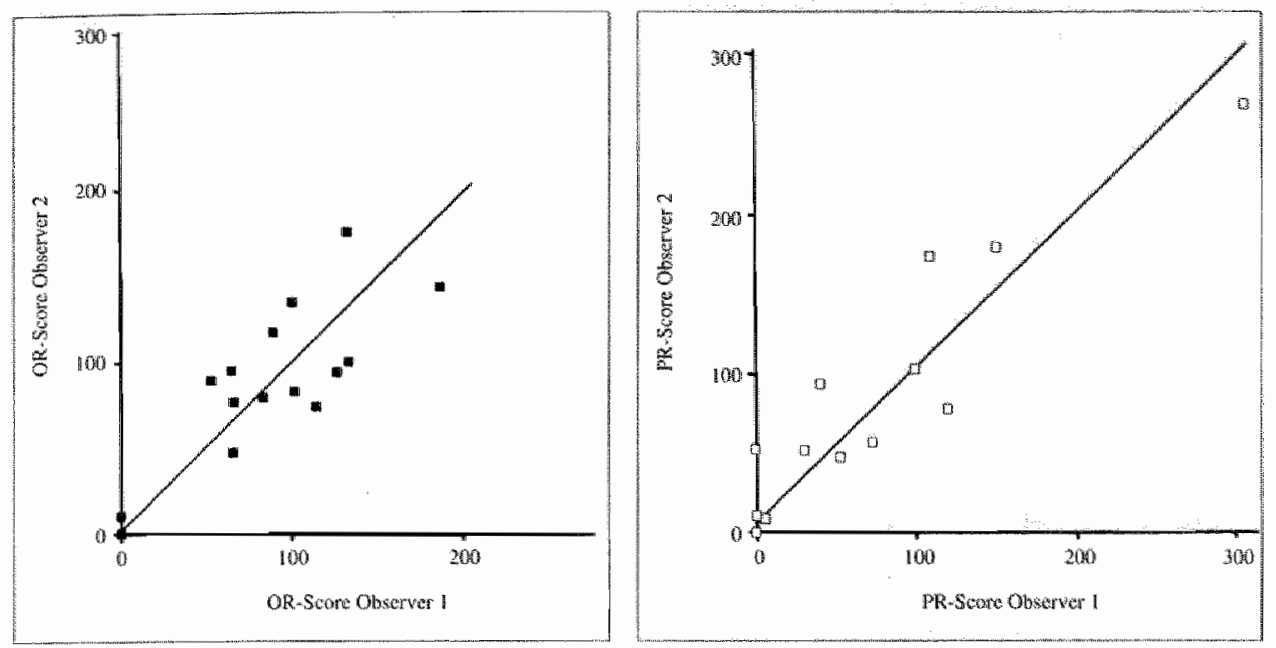

Fig. 3. Inter-observer variability of OR score (D) and PR score $\square$ in 16 endometrial cancer. samples (for OR score: $r=0.84, P<0.0001$; for $P R$ score: $r=0.93, P<0.00001$ )

sample as measured with a radiochemical assay, the immunoreactivity of the normal tissue in each section was evaluated. Also, receptor levels of two post-menopausal myometrium samples were assayed with immunohistochemistry and radioligand binding.

The majority of the carcinomas (13/16) was found to be OR-positive with immunohistochemistry. Nine of these were also found to be PR-positive. No OR-negative PR-positive cases were encountered. Comparison of immunohistochemical scoring of tumour cells with radioligand binding assay gave a concordance of $75 \%(12 / 16)$ for $O R$ and $44 \%(7 / 16)$ for PR.

Evidently, as is shown by both immunohistochemical and radiochemical receptor analysis, normal uterine tissue elements contain considerable amounts of OR ad PR. In the majority of cases, the discordance between receptor immunohistochemistry of tumour epithelium and radiochemistry of tissue sections could be explained on the basis of contaminating normal tissue. When the immunoreactivity of normal tissue was taken into account, a concordance of $81 \%$ (13/16) for OR and $75 \%(12 / 16)$ for PR was found. In four samples, significant discrepancies were observed. In specimens 5 and 13 , no receptor could be demonstrated with the antibody whereas the radioligand binding assay indicated the presence of receptor. In contrast, receptor positivity was found with immunohistochemistry in samples 12 and 16 whereas no receptor could be detected with radioligand binding assay 
Table 1. Comparison of inmunohistochemisty with radioligand binding assay for $O R$ and $P R$ levels in lo endometrial carcinama specimens:

\begin{tabular}{|c|c|c|c|c|c|c|c|c|}
\hline \multirow[b]{2}{*}{$\begin{array}{l}\text { Relative } \\
\text { content } \\
\text { off tumour } \\
\text { epithelium } \\
\text { in section }\end{array}$} & \multirow[b]{2}{*}{$\begin{array}{c}\text { Tumour } \\
\text { No. }\end{array}$} & \multirow[b]{2}{*}{$\begin{array}{l}\text { Histological } \\
\text { grade }\end{array}$} & \multicolumn{3}{|c|}{ Oestrogen receptor } & \multicolumn{3}{|c|}{ Progesterone receptor } \\
\hline & & & $\begin{array}{l}\text { Histo } \\
\text { Tumour } \\
\text { tissue } \\
\text { (OR } \\
\text { score) }\end{array}$ & $\begin{array}{c}\text { Normal } \\
\text { tissue }\end{array}$ & $\begin{array}{c}\text { Radiot } \\
\text { Total } \\
\text { section } \\
\text { (fmol/mg } \\
\text { protein) }\end{array}$ & $\begin{array}{l}\text { Histo* } \\
\text { Tumour } \\
\text { tissue } \\
\text { (PR } \\
\text { score) }\end{array}$ & $\begin{array}{l}\text { Normal } \\
\text { tissue }\end{array}$ & $\begin{array}{l}\text { Radiot } \\
\text { Total } \\
\text { section } \\
\text { (fmol/mg } \\
\text { protein) }\end{array}$ \\
\hline \multirow[t]{7}{*}{$>75 \%$} & 1 & $\mathbb{1}$ & $+t(166)$ & - & $t+(206)$ & $t+(168)$ & + & $+t+(1424)$ \\
\hline & 2 & [] & $+(57)$ & - & $+(40)$ & $+(43)$ & + & $+t+(275)$ \\
\hline & 3 & II & $+(72)$ & + & +99 & $\frac{1}{4}+(103)$ & + & $+t+(408)$ \\
\hline & 4 & 11 & $+(94)$ & - & $+(42)$ & $-(14)$ & + & $+(121)$ \\
\hline & 5 & $\| I$ & $-\quad(0)$ & - & $+(67)$ & $-(0)$ & - & $+\quad(59)$ \\
\hline & 6 & $\mathbb{I I}$ & $+(71)$ & - & $+(19)$ & $-(0)$ & + & $+\quad(55)$ \\
\hline & 7 & III & $-\quad(7)$ & $+t$ & $++(174)$ & $-(5)$ & ++ & $t+(182)$ \\
\hline \multirow[t]{6}{*}{$50-75 \%$} & 8 & I & $+t(1.10)$ & - & $+(31)$ & $+(98)$ & - & $+(66)$ \\
\hline & 9 & I & $++(103)$ & + & $+(35)$ & $-\quad(0)$ & + & $++(139)$ \\
\hline & 10 & II & $+(80)$ & $+t$ & $++(101)$ & $+(65)$ & - & +601 \\
\hline & 11 & II & $++(15 \|)$ & + & $++(114)$ & $+(68)$ & ++ & $++(154)$ \\
\hline & 12 & II & $++(117)$ & + & $+(21)$ & $++(141)$ & - & $-\quad(0)$ \\
\hline & 13 & III & $-\quad(0)$ & + & +981 & $-(0)$ & - & $++(128)$ \\
\hline \multirow[t]{3}{*}{$25-50 \%$} & 14 & I & $+(97)$ & $+t$ & $t+(133)$ & $-(28)$ & + & $+\quad(81)$ \\
\hline & is & II & $+(81)$ & - & $+(16)$ & $t+t(288)$ & + & $+++(278)$ \\
\hline & 16 & II & $++(116)$ & + & $-(7)$ & $+(52)$ & - & $-\quad(0)$ \\
\hline $\begin{array}{l}0 \% \\
\text { (myometrium) }\end{array}$ & & & & $\begin{array}{l}+t \\
+t\end{array}$ & $\begin{array}{l}t+(198) \\
t+(149)\end{array}$ & & $\begin{array}{l}++ \\
++\end{array}$ & $\begin{array}{r}++(274) \\
++(157)\end{array}$ \\
\hline
\end{tabular}

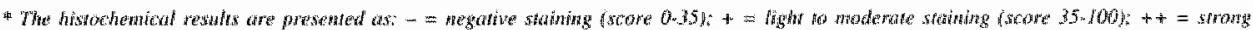

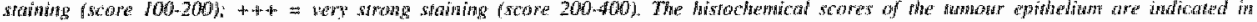
parontihesest

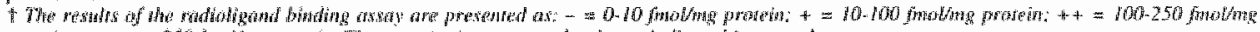

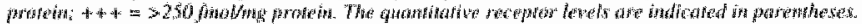

\section{Discussion}

Two different methods of steroid hormone receptor analysis in carcinoma of the endometrium were studied. Special attention was paid to the impact of tissue heterogeneity on the validity of the results. Radiochemical and immunohistochemical assays were performed on directly adjacent tissue sections.

With the radiochemical section assay, the OR and PR levels in endometrial cancer specimens could be reliably estimated using Scatchard analysis. This type of assay requires less tissue than the cytosol assay and is very useful when only a small tissue sample is available $(15-17,21)$. Steroid receptor immunohistochemistry yields cellular localization as well as semiquantitative assessment of the receptor in the same section. This approach allows direct comparison of radiochemical and 
immunohistochemical steroid receptor assay with minimal sampling errors $(16,22-24)$. Histological examination of sections revealed up to $75 \%$ admixture of benign tissue elements, which appeared to contain significant levels of OR and PR (Table 1 ). It is therefore quite conceivable that tissue samples obtained for radiochemical receptor determination on cytosol differ significantly in composition, which may lead to receptor values not representative for the tumour epithelium. We conclude that rigorous histological control of tissue specimens is necessary for a reliable radioreceptor assay.

An immunocytochemical assay might be the ideal approach because it alows assessment of the receptor status of the individual cells. Until now, few studies have reported on the immunohistochemical detection of OR or PR in cancer of the endometrium (24-27). We found heterogeneous nuclear staining of OR and PR in normal and tumour cells, in agreement with other studies. In spite of the heterogeneous receptor distribution, the interobserver variability in semiquantitative receptor scoring of tumour epithelium was found to be negligible, as was previously reported for breast cancer (16).

In breast cancer, the semiquantitative immunohistochemical OR score of the tumour epithelium was found to correlate well with the results of the radiochemical assay on cytosol and even better with those on adjacent sections (16). For endometrial carcinoma, it has been reported that immunocytochemical evaluation may reliably assess receptor status. Budwit-Novotny et al. (25) observed excellent sensitivity and specificity for immunohistochemical analysis of OR. Pertschuk et al. (26), who considered tumours immunohistochemically OR-positive if $10 \%$ or more of the malignant cells were stained, observed $83 \%$ concordance with radiochemical cytosol analysis. For PR, Zaino et al. (27) found an equally high correlation of $83 \%$ between the results obtained by the two methods. In the present study, the correlation between tumour immunohistochemistry and radiochemical section assay results was not found to be linear for either the OR or the PR.

Indeed, quantitative estimates of receptor levels in endometrial and breast cancer have shown significant discrepancies which are related, most probably, to tissue heterogeneity $(10,12,27,28)$. In this study, the majority of the discrepancies between tumour immunohistochemistry and radiochemistry could be explained by contribution of surrounding benign tissue elements to the total radiochemical receptor values.

Some cases yielding negative or low positive results by radioligand binding assay but positive by immunohistochemical assay were due to admixture of a relatively small number of receptor-positive malignant cells with low or negative benign material. A second reason for discordance can be that monoclonall antibodies recognize epitopes that are distinct from the hormone binding sites of the receptor. Occupied receptor molecules may escape radiochemical detection but remain detectable by immunohistochemistry. 
Several cases yielding negative or low positive results by immunohistochemical assay but positive by radioligand binding assay were due to admixture of receptorpositive non-neoplastic cells from the surrounding benign tissue elements, which are not taken into account in the histochemical score. Furthermore, immunohistochemistry might not be sufficiently sensitive to detect very low concentrations of hormone receptor. Alternatively, in some specimens the ligand binding function is apparently better preserved than the receptor epitopes for antibody binding.

In conclusion, immunohistochemical receptor scoring can be reliably performed despite extensive heterogeneity, as evidenced by low interobserver variability and correct classification in receptor-positive and -negative cases when compared to the radioligand binding assay. For endometrial carcinoma, the immunohistochemical approach would appear an essential alternative to the radiochemical assay because it allows assessment of receptor expression in tumour cells in a heterogeneous specimen. Immunohistochemical receptor content may allow more accurate prediction of the response of endometrial carcinomas to endocrine therapy.

\section{Acknowledgements}

The authors wish to thank Mrs Debets-Te Baerts of the Pathology Laboratory of De Wever Hospital, Heerlen for expert technical performance of the histochemical procedures. This study was partly supported by grant RUL 85-3 from the Netherlands Cancer Foundation K.W.F.

\section{References}

1 Lippman ME. Steroid hormone receptors and mechanisms of growth regulation of human breast cancer. In: Diagnosis and Management of Breast Cancer. Mauke D, ed. Philadelphia, WB Saunders 1988, 326-347

2 Taylor RW. The treatment of endometrial carcinoma with medroxyprogesterone acetate. In: Role of Medroxyprogesterone in Endocrine Related Tumors. Campio L, Robustelli della Cuna G\& Taylor RW, eds. Vol. II. New York, Raven Press 1983, 157-162

3 Bokhman JV, Chepick OF, Volkova AT \& Vishnevsky AS. Can primary endometrial carcinoma stage 1 be cured without surgery and radiation therapy? Gynecol Oncol 1985, 20: $139 \cdot 155$

4 Lewis GC, Slack NH, Mortel R \& Bross ID. Adjuvant progestogen therapy in the primary definitive treatment of endometrial cancer. Gynecol Oncol 1974, 2: 368 - 376

5 Macdonald RR, Thorogood J \& Mason MK. A randomized trial of progestogens in the primary treatment of endometrial carcinoma. Br J Obstet Gynaecol 1988, 95: 166 - 174

6 Ehrlich CE, Young PC, Stehman FB, Sutton GP \& Alford WM. Steroid receptors and clinical outcome in patients with adenocarcinoma of the endometrium. Am J Obstet Gynecol 1988, 158: $796-807$ 
7 Palmer DC, Mair IM, Alexander AI, Cauch M, Bennett RC \& Quinn MA. The prognostic importance of steroud receptors in endometrial carcinoma. Obstet Gynecol 1988, 72: 388 - 393

8 Chambers JT, MacLuskey N, Eisenfield A, Kohorn EI, Lawrence R \& Schwartz PF. Estrogen and progestin receptor levels as prognosticators for survival in endometrial cancer. Gynecol Oncol 1988, 31:65-77

9 Quinn MA, Cauchi M \& Fortune D. Endometrial carcinoma: steroid receptors and response to medroxyprogesterone acetate. Gynecol Oncol 1985, 21:314-319

10 Castagnetta L, Lo Casto M, Granata OM, Calabro M, Ciaccio M \& Leake RE. Soluble and muclear oestrogen receptor status of advanced endometrial cancer in relation to subsequent clinical prognosis. Br J Cancer 1987, 55:543 - 546

11 Soper JT, McCarty KS Jr, Creasman WT \& McCarty KS Sr. Histologic control of biochemical steroud receptor analysis in endometrial carcinomas. Am J Obstet Gynecol 1985, $153: 520-523$

12 Mortel R, Zaimo $\mathbf{R} \&$ Satyaswaroop PG. Heterogeneity and progesterone receptor distribution in endometrial adenocarcinoma. Cancer 1984, 53:113-116

13 Press MF, Nousek-Groebl NA, Bur M \& Greene GL. Estrogent receptor localization in the female genital tract. Am J Pathol 1986, 123: 280 - 292

14 Perrot-Applanat M, Logeat F, Groyer-Picard MT \& Milgrom E. Immunocytochemical study of mammalian progesterone receptor using monoclonal antibodies. Endocrinol 1985 , 116: $1473-1484$

15 De Goeij AF, Volleberg MP, Hondius GG \& Bosman FT. Radiochemical determination of oestrogen receptors in cryostat sections of target tissues. J Steroid Biochem 1984, 21: 127 - 134

16 Scheres HM, De Goeij AF, Rousch MJ et al. Quantification of oestrogen receptors in breast cancer: radiochemical assay on cytosols and cryostat sections compared with semiquantitative immunocytochemical analysis. J Clin Pathol 1988,41:623 - 632

17 De Goeij AF, Scheres HM, Rousch MJ, Hondius GG \& Bosman FT. Progesterone receptor quantification with radiolabelled promegestone (R5020) in frozen sections of endometrium and breast cancer tissue. J Steroid Biochem 1988, 29: 465 474

18 Bradford MM. A rapid and sensitive method for the quantification of microgram quantities of protein utilizing the principle of protein dye binding. Anal Biochem 1976, 72: 248 - 254

19 Schutte B, Reynders MM, Van Assche CL, Hupperets PS, Bosman FT \& Blijham GH. A.l improved method for the immunocytochemical detection of bromodeoxyaridine labelled nuclei using flow cytometry. Cytometry 1987, 8: $372-376$

20 McCarty KS Jr, Miller LS, Cox EB, Konrach J \& McCarty KS Sr. Estrogen neceptor analysis. Correlation of biochemical and immunohistochemical methods using monoclonal antireceptor antibodies. Arch Pathol Lab Med 1985, 109: $716-721$

21 Underwood JC, Dangerfield VJ \& Parsons MA. Oestrogen receptor assay of cryostat sections of human breast carcinomas with simultaneous quantitative histology. J Clin Pathol $1983,36: 399 \cdot 405$

22 Giri DD, Goepel GR, Rogers K \& Underwood JC. Immunohistochemical demonstration of progesterone receptor on breast carcinomas: correlation with radioligand binding assays and oestrogen receptor immunohistology. J Clin Pathol 1988, 41: 444 - 447

23 Giri DD, Dangerfield VJ, Lonsdale R, Rogers K \& Underwood JC. Immunohistology of oestrogen receptor and DS antigen on breast cancer: correlation with oestrogen receptor content of adjacent cryostat sections assayed by radioligand binding and enzyme immunoassay. J Clin Pathol 1987, 40:734 - 740 
24 Thormton IG \& Wells M. Oestrogen receptor in glands and stroma of nomal and neoplastic endometrum: a combined biochemical, ionmunohistochemical and morphometric study. J Clin Pathol 1987, 40:1437-1442

25 udwitwovotny DA, McCarty KS, Cox EB et al. Immunohistochemical analyses of estrogen receptor in endometrial adenocarcinoma using a monoclonal antibody. Cancer Res $1986,46: 5419-5425$

26. Pertschuk LP, Beddoe AM, Gorelic LS \& Shain SA. Immunocytochemical assay of estrogen receptors in endometrial carcinoma with monoclonal antibodies. Comparison with biochemical assay. Cancer 1986, 57: $1000-1004$

27 Zaino RJ, Clarke CL, Mortel R \& Satyaswaroop PG. Heterogeneity of progesterone receptor distribution in human endometrial adenocarcinoma. Cancer Res 1988, 48: $1889-1895$

28 Parl IT Posey YF. Discrepancies of the biochemical and imunohistochemical estrogen receptor assays in breast cancer. Hum Pathol 1988, 19:960-966 


\section{CHAPTER 3}

\section{Immunocytochemical analysis of oestrogen and progesterone receptors in paraffin sections ${ }^{*}$}

* from: Snijders M, Theunissen P, Debets - Te Baerts M \& Koudstaal Joh.

Immunhistochemischer Nachweis won Östrogen- und Progesteronrezeptoren in Paraffinsclnitten.

Der Pathologe 1990, 11: $236-239$ 


\section{Summary}

An immunocytochemical assay for the determination of oestrogen (OR) and progesterone receptors (PR) in routinely-fixed, paraffin-embedded uterine tissue sections has been developed, based on methods described in recent reports. To increase the sensitivity of immunostaining several methods were applied including enzymatic pretreatment to expose the antigenic sites, adjustment of incubation times and the use of sensitive immunoperoxidase techniques. However, throughout this study routinely formalin-fixed and paraffin-embedded tissue was used. Highly significant linear correlations (for OR: $r=0.96, P<0.00001$; for $P R: r=0.96, P<$ $0.00001)$ between semiquantitative receptor scores on frozen and paraffin sections from 35 adjacent human endometria show that consistent immunocytochemical staining can be achieved on formalin-fixed, paraffin-embedded uterine tissue sections.

\section{Introduction}

Steroid hormones regulate the growth of several hormone-responsive tumours like breast and endometrial carcinoma. It is generally accepted that the presence of oestrogen receptors (OR) in breast cancer is correlated with a longer disease-free survival and a better response to hormonal therapy $(1,2)$. Also, expression of the progesterone receptor (PR) appears important for the prognosis in breast $(1,3,4)$ and endometrial cancer (5), as its detection implies a functional $O R$.

The widely used radiochemical (dextran-coated charcoal) receptor assay is relevant for clinical use, but has several drawbacks: the analysis is performed on a (tumour) tissue homogenate, which does not allow a reliable estimation of receptor content of different tumour parts. Moreover, a tumour sample may not contain tumour cells only, but also a various amount of stromal and other non-tumour cells. This 'contamination' may be significant in particular in human endometrium where the stromal cells contain considerable amounts of steroid receptors $(6,7)$. In this respect, radiochemical receptor analysis in cytosol may lead to false negative as well as false positive results $(6,8,9)$. It is concluded that the radiochemical cytosolic receptor assay does not permit a reliable assessment of the actual steroid receptor content of tumour cells in a heterogeneous tissue specimen.

Immunocytochemical receptor staining directly demonstrates $O R$ and $P R$ in the cellular nuclei, thus coping with the problem of cellular heterogeneity in tumour tissue for receptor analysis (10). In breast cancer, the results of several studies have shown significant correlations between radiochemical and immunocytochemical determination of steroid receptor content $(4,9,11-14)$. Consequently, the immuno- 
cytochemical analysis of $\mathrm{OR}$ and $\mathrm{PR}$ has gained wide acceptance in the management of patients with breast cancer. In endometrial carcinoma, these correlations have been shown to be much weaker, a finding which has been mainly attributed to cellular heterogeneity $(6,15)$.

At present, the immunocytochemical receptor assay is performed almost exclusively on cryostat sections. Previous attempts to detect steroid receptors in routinely formalin-fixed tissues have been unsuccessful, presumably due to the loss of receptor antigenicity during processing. However, the use of paraffin sections has important advantages when compared to frozen sections: it permits excellent preservation of histomorphology, retrospective analysis on paraffin-embedded archival tumour tissues, as well as studies on very small tissue samples where routine processing of all the limited tissue available is necessary for histomorphological diagnosis. The purpose of the present study was to define the immunocytochemical procedures enabling a reliable semiquantitative analysis of OR and PR at the cellular level using paraffin-embedded uterine tissues.

\section{Materials and methods}

Several modifications have been reported for detection of $O R$ in paraffin sections. These include the use of receptor preserving-fixation fluids and techniques, fixation at low temperature, and methods to enhance the sensitivity of immunostaining, e.g extension of incubation times, enzymatic pretreatment of sections, and the use of immunoperoxidase techniques with high affinity. The reported modifications are listed in Table 1.

In the present study, several modifications of the immunocytochemical receptor staining technique were tested on a series of paraffin sections from 35 human endometria and the results were compared with the reported procedure $(6,13)$ on frozen sections of adjacent uterine tissue blocks. OR and PR expression in both glandular epithelial and stromal cells was analysed. Routine tissue fixation with $4 \%$ buffered formalin was used as this is a standard procedure in the diagnostic pathology laboratory. Enzymatic pretreatment of paraffin sections was performed with trypsin or DNase. The primary rat anti-OR monoclonal antibody (H222 SP $\gamma$, ER-ICA kit, Abbott Laboratories, The Netherlands) and monoclonal mouse anti-PR antibody (mPR1, ITK Diagnostics, The Netherlands) were tested in a dilution series. The binding of the primary antibody was demonstrated using either avidin-biotinperoxidase complex $(A B C)$ or streptavidin-biotin peroxidase. Sections of OR- and PR-positive human mammary carcinoma and/or virginal rabbit uterus served as positive controls in every staining procedure. As negative controls, paraffin and frozen sections of human endometria were stained according to the same procedures but normal ("non-immune') rat IgG was used instead of rat anti-OR antibody and 
Table 1. Summary of modificutions, applied for ismmunocytochemical analysis of steroid receptors in paraffin wections

\section{type of fixation}

- $10 \%$ buffered-formalin (0.1 M Natriumphosphate; pH 7.4) for 24 h at $4^{\circ} \mathrm{C}(16-18)$

- Bouin"s solution for 0.524 b at room temperature (RT) $(16,19)$

- picric-acid-formalim (PAF) for $22 \mathrm{~h}$ at $4^{\circ} \mathrm{C}$ (17)

- Methacarn (methanol.chloroformacetic acid $=6: 3: 1$ ) for $4-24$ h at $4^{\circ} \mathrm{C}(20)$

- Carson"s buffered-formalin for $24-28$ h at $4^{\circ} \mathrm{C}(20)$

\section{enzymatic pretreatment}

- trypsin (1 ung trypsin/ml $0.1 \% \mathrm{CaCl} 2$ in $0.05 \mathrm{M} \mathrm{NaHCO}, \mathrm{pH} 8.0)$ for $15-60 \mathrm{~min}$ at $37^{\circ} \mathrm{C}$ $(21,22)$

- DNase-solution ( $5 \mathrm{mg} / \mathrm{ml}$ in $0.05 \mathrm{M}$ Tris buffer solution and $0.01 \mathrm{MgSO}$, pH 7.4) for $2 \mathrm{~h}$ at RT $(20,23,24)$

* pronase $(0.03 \mathrm{~g} / 50 \mathrm{ml}$ phosphate-buffered saline $=\mathrm{PBS})$ for $9 \mathrm{~min}$ at $37^{\circ} \mathrm{C}(25)$

- trypsin for 5 min, followed by DNase-solution for 10 min (26)

\section{detection systems}

- avidin-biotin peroxidase complex (ABC) $(16,18,19,25)$

- streptavidin-biotin peroxidase complex (20)

- $10 \mu \mathrm{l} 0.1 \mathrm{M}$ imidazol/ml chromogen (6) and cobaltchloride $(0.02 \%)$ (26) to intensificate the chromogen diaminobenzidine (DAB)

'non-immune' mouse IgG instead of mouse anti-PR antibody. The immunocytochemical procedures yielding optimal results for OR and PR analysis on paraffin sections are presented in Table 2.

The validity of steroid receptor immunostaining in paraffin sections was tested by calculating the correlations between semiquantitative receptor scores on frozen and paraflin sections. Statistical significance was assessed by regression analysis (Statgraphics software). The intensity and distribution of specific staining were evaluated visually using semiquantitative scoring of immunoreactivity $(6,13)$.

The immunocy tochemical receptor score was expressed as follows:

receptor score $=\sum_{i=0}^{i=4} P(i) \times i$

where $\mathrm{i}=$ intensity of staining from 0 (which is no staining) to 4 (which is very intense staining) and $\mathrm{P}(\mathrm{i})$ is percentage of stained cells in category $\mathrm{i}(0-100 \%)$. Classification of staining intensity was assessed for each cell type on at least three separate cohorts of 100 cells in different high power $(x 400)$ fields. The final receptor score (maximum 400) was obtained by calculating the mean of the cohorts. Intra- and interobserver reproducibility of the scoring method has been reported previously $(6,13)$. 
Table 2. Imwnocytochemical procedure for $O R$ and PR analysis in rounely-fuxed paraffinembedded sections

paraffin sections are cut at 5 tm from $4 \%$ buffered-formalin fixed tissue samples and mounted on gelatin chromealum-coated glass slides, deparaffinized with xylene and rehydrated

enzymatic pretreatment for $O R$ analysis only:

digestion with DNase solution (5 mg/ml DNase, Sigma Pharmaceuticals D5025, in $0.05 \mathrm{M}$ Tris buffer-solution. pH 7.4 and $0.01 \mathrm{M} \mathrm{MgSO}$ ) for $2 \mathrm{~h}$ at RT (or $1 \mathrm{~h}$ at $37^{\circ} \mathrm{C}$ ) or with bovine pancreatic trypsin solution ( $1 \mathrm{mg} / \mathrm{ml} 0.1 \% \mathrm{CaCl}_{2}, \mathrm{pH} 7.8$ ) for $30 \mathrm{~min}$ at $37^{\circ} \mathrm{C}$

washing in phosphate-buffered saline (PBS), pH 7.2-7.4

\section{OR analysis:}

four incubations with immunoreagents, alternated with washings in PBS at RT

1. blocking reagent: normal $20 \%$ sheep serum, $15 \mathrm{~min}$

2. primary rat anti-OR antibody (H222 SP $\gamma$, ER-ICA, Abbott) undiluted, ovemight at RT

3. bridging antibody: biotinylated sheep anti-rat immunoglobulin (Amersham International, UK) $1: 200,2$ h at RT

4. avidin-biotin peroxidase complex (ABC, Vector Laboratories, USA) 1:200, 2 h at RT

\section{PR analysis:}

four incubations with immunoreagents, alternated with washings in PBS at RT

1. blocking reagent: normal $20 \%$ sheep serum, $15 \mathrm{~min}$

2. primary mouse anti-PR antibody (mPR 1, ITK) $1: 800$, overnight at $4^{\circ} \mathrm{C}$

3. bridging antibody: biotinylated sheep anti-mouse immunoglobulin (Amersharn) $1: 200,90 \mathrm{~min}$ at RT

4. peroxidase labelled-streptavidin (TTK) $1: 1000,90$ min at RT

\#ncubation with chromogen substrate-solution containing diaminobenzidine (DAB) with addition of $10 \mu \mathrm{l} 0.1 \mathrm{M} \mathrm{imidazol} / \mathrm{ml} \mathrm{DAB}, 7 \mathrm{~min}$ in the dark

counterstaining of cell nuclei with Harris' haematoxylin $5-10 \mathrm{sec}$

\section{Results}

With respect to enzymatic pretreatment of paraffin sections, equal immunostaining results were obtained either with the use of DNase or trypsin. Optimal conditions for immunostaining were achieved by a pretreatment period of $60 \mathrm{~min}$ with DNase at $37^{\circ} \mathrm{C}$ or by incubating 30 min with trypsin at $37^{\circ} \mathrm{C}$. Only for $\mathrm{OR}$ detection, enzymatic pretreatment led to a higher sensitivity without an increase in non-specific staining that could interfere with the interpretation of receptor immunoreactivity.

With respect to the use of immunoreagents to detect the receptor-specific antibodies, streptavidin-biotin peroxidase increased the staining intensity for PR detection more than $\mathrm{ABC}$-peroxidase. Using this technique, the primary anti-PR antibody could be 

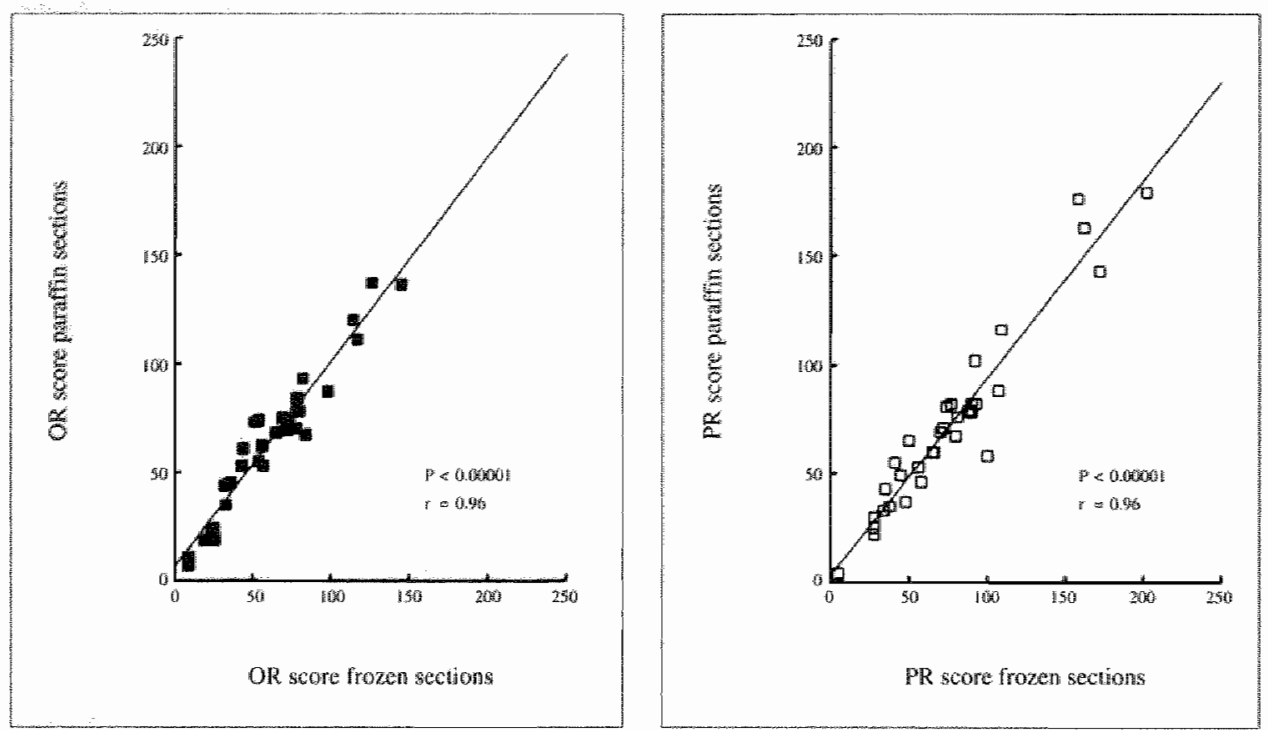

Fig. 1. Comparison of inmunocytochemical receptor scores for $O R(\mathbf{D})$ and $P R(\mathrm{D})$ in frozen and paraffin sections of 35 human endometrial tissue samples

diluted up to 1:800 without a loss of specific staining intensity. For OR analysis, satisfying results were obtained using $\mathrm{ABC}$-peroxidase, but the anti-OR antibody had to be used undiluted. The addition of imidazol to the chromogen solution resulted in a marked increase in staining intensity both in OR and in PR analysis.

As is shown in Fig.1, regression analysis revealed highly significant linear correlations between the receptor scores on frozen and paraffin sections: for $O R$, $r=0.96 ; P<0.00001$ and for $P R, r=0.96 ; P<0.00001$.

\section{Discussion}

Recently, several authors have described immunocytochemical techniques for the detection of OR in paraffin sections by using modifications of the procedures used on cryostat sections. In the present study, these techniques are successfully applied for $O R$ as well as PR anallysis on paraffin sections, the latter which has been reporled recently by Perrot-Applanat et all. (17). For positive OR immunostaining enzymatic pretreatment with DNase or trypsin was required, a finding which is in accordance with earlier reports. In this respect it must be noted that the DNase reagent may show variable activity, leading to inconsistencies of staining (27). For $P R$, it was found that enzymatic digestion of paraffin sections did not improve specific immunostaining, which is in concordance with Perrot-Applanat et al. (17). 
Table 3. Summary of studies comparing immunocytochemical OR and PR analysis on frozen and parafin sections

\begin{tabular}{llllll}
\hline author & OR/PR & fuxative & pretreatnent & marker & $\begin{array}{c}\text { concordance } \\
\text { \% }\end{array}$ \\
\hline Shimada (18) & OR & F & - & ABC & 88 \\
De Rosa (16) & OR & B & - & ABC & 92 \\
& OR & F, $4^{\circ} \mathrm{C}$ & - & ABC & 93 \\
Shintaku(24) & OR & F & DNase & PAP & 94 \\
Hiont (26) & OR & F & T/DNase & PAP CoCL & 100 \\
Perrot-Applanat (17) & PR & PAF & - & PAP & 78 \\
Paterson (20) & OR & C & DNase & PAP & 78 \\
& OR & M & DNase & ABC & 81
\end{tabular}

F: formalin, B: Bowin's solution, PAF; picrin-acid formalin, C: Carson's formalin, $M$ : methacarn, $T$ : trypsin

With respect to immunoperoxidase-amplification systems, Milde et al. have shown that a superior staining intensity can be achieved with the streptavidin-biotin peroxidase complex (28). In the present study this is confirmed in the analysis of $\mathrm{PR}$, however, for OR analysis the streptavidin peroxidase complex led to unacceptable background staining. Imidazol yields a further intensification of staining, as was reported earlier (6). When comparing the procedures for $O R$ and $P R$ detection in paraffin sections, it appeared that OR analysis was more technically demanding: enzymatic pretreatment is required and the use of immunoreagentia with high affinity leads to unacceptably high background staining.

Several studies $(16-18,20,24,26)$ have dealt with qualitative assessment of receptorstatus (i.e. receptor positive or -negative) using OR immunocytochemistry on cryostat and paraffin sections (see Table 3). However, the different modifications were not compared systematically, and hence the most appropiate method for standard use cannot be established from these studies. All reports stated that the intensity of immunocytochemical staining was weaker in paraffin sections than in frozen sections.

In the present study, quantitative correlations between results of receptor scoring on cryostat and paraffin sections were calculated. The highly significant linear correlations between the immunostaining results on cryostat and paraffin sections from adjacent uterine specimens indicate that antigenic reactivity is equally well preserved in both types of tissue sections and that equivalent results of semiquantitative $O R$ and PR scoring can be obtained. 


\section{Acknowledgements}

The authors are indebted to M. Rousch, Department of Pathology, University of Limburg, Maastricht, for his advice with regard to the immunocytochemical procedures and preparation of the manuscript.

\section{References}

1 De Sombre ER. Breast cancer: homone receptors, prognosis and therapy. Clin Oncol 1982 , I. $191-213$

2 Lippman ME. Steroid hormone receptors and mechanisms of growth regulation of human breast cancer. In: Diagnosis and Management of Breast Cancer. Mauke D, ed. Philadelphia, Saunders 1988: $326-347$

3 Pertschuk LP, Feldman JG, Byer Eisenberg $K$ et al. Immunocytochemical detection of progesterone receptor in breast cancer with monoclonal antibody. Cancer 1988,$62 ; 342-349$

4 Romay G, Sponsel N, Merkle E \& Tulusan AH. Progesteronrezeptoren beim Mammakarzinom. Pathologe $1990,11: 4-9$

5 Creasman WT, Soper JT, McCarty KS Jr, McCarty KS Sr, Hinshaw W \& ClarkePearson DL. Influence of cytoplasmic steroid receptor content on prognosis of early stage endometrial carcinoma. Am J Obstet Gynecol 1985, 151:922 - 932

6 Snijders MP, De Goeij AF, Koudstaal Joh et al. Is immunohistochemical analysis of oestrogen and progesterone receptors in endometrial carcinoma superior to the radioligand binding assay? J Pathol 1990, 161: 129-135

7 Soper JT, McCarty KS Jr, Creasman WT \& McCarty KS Sr. Histologic control of biochemical steroid receptor analysis in endometrial carcinomas. Am J Obstet Gynecol 1987 , 153: $520-523$

8 Parl FI \& Posey YF. Discrepancies of the biochemical and immunohistochemical estrogen receptor assays in breast cancer. Hum Pathol 1988, 19:960-966

9 Shousha S, Stamp T, James KR \& Alaghband-Zadeh J. Immunohistochemical study of oestrogen receptors in breast carcinomas that are biochemically receptor negative. $\mathrm{J}$ Clin Pithol 1990, 43: $239-242$.

10 Press MF \& Greene GL. Immunocytochemical localization of estrogen and progesterone receptors. In: Advances in Immunocytochemistry. DeLellis RA, ed. New York Raven Press $1988: 341-361$

11 Neumann K, Ruschoff J, Horstmann A, Zwiorek L \& Kalbfleisch H. Hormonrezeptorgehalt won Mammakarzinomen. Vergleich morphologischer und biochemischer Bestimmungsmethoden. Pathologe 1989, 10: 160-164

12 Schar A, Vierbuchen M \& Wurz H. Immunhistochemischer Nachweis von Östrogen- und Progesteronrezeptoren beim Mammakarzinom mit Hilfe monoklonaler Antikörper: Vergleich mit der biochemischen Rezeptoranalyse. Parhologe 1989, 10:31-38

13 Scheres HM, De Goeij AF, Rousch MJ et al. Estrogen receptor quantification in human. breast cancer: madiochemical assay on cytosol and cryostat sections compared with semiquantitative immunocytochemical analysis. J Clin Pathol 1988,41:623-632 
14 Weikel $\mathbf{W}$, Rosenthal $\mathrm{H}_{\text {, }}$ Beck Th \& Mitze H. Immunhistochemischer Nachweis von Progesteronrezeptoren am Mammakarzinom. Pathologe 1990, 11:85-88

15 Zaino RI, Clarke CL, Mortel R \& Satyaswaroop PG. Heterogeneity of progesterone receptor distribution in human endometrial adenowarcinoma. Cancer Res 1988, 48: 1889-1895

16 De Rosa CM, Ozello L, Greene GL \& Habif DV. Immunostaining of estrogen receptor in paraffin sections of breast carcinomas using monoclonal antibody D75P3y: effects of fixation. Am J Surg Pathol 1987, 11: $943-950$

17 Perrot-Applanat M, Groyer-Picard MT, Vu Hai MT, Pallud C, Spyratos $F$ \& Milgrom E. Immunocytochemical staining of progesterone receptor in paraffin sections of human breast cancers. Am J Pathol 1989, 135: 457 - 468

18 Shimada $\mathbf{A}$, Kimura $S$, Abe $K$ et al. Immunocytochemical staining of estrogen receptor in paraffin sections of human breast cancer by use of monoclonal antibody: comparison with that in frozen sections. Proc Natl Acad Sci USA 1985, 82: 4803 - 4807

19 Poulsen HS, Oxello L, King WJ \& Greene GL. The use of monoclonal antibodies to estrogen receptors (ER) for immunoperoxidase detection of ER in paraffun sections of human breast cancer tissue. J Histochem Cytochem 1987, 33: 87-92

20 Paterson DA, Reid CP, Anderson TJ \& Hawkins RA. Assessment of oestrogen receptor content of breast carcinoma by immunohistochemical techniques on fixed and frozen tissue and by biochemical ligand binding assay. J Clin Pathol 1990, 43:46-51

21 Andersen J, Orntoft T \& Poulsen HS. Semiquantitative oestrogen receptor assay in formalinfixed paraffin sections of human breast cancer tissue using monoclonal antibodies. Br I Cancer $1986,53: 691-694$

22 Bur ME, Greene GL \& Press MF "Estrogen receptor localization in formalin-fixed, paraffinembedded endometrium and endometriotic tissue. Int J Gynecol Pathol 1987, 6: 140 - 15

23 Cohen C, Unger E, Sgontas D, Bradley N \& Chenggis M. Automated immunohistochemical estrogen receptor in fixed embedded breast carcinomas. Comparison with manual immunohistochemistry on frozen sections. Am J Clin Pathol 1989, 92: 669-672

24 Shintaku IP \& Said JW. Detection of estrogen receptors with monoclonal antibodies in routinely processed formalin-fixed paraffin sections of breast carcinoma. Use of DNase pretreatment to enhance sensitivity of the reaction. Am J Clin Pathol 1987, 2: 161 - 167

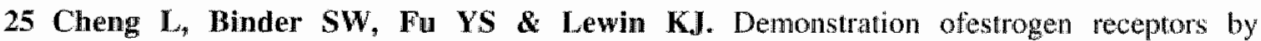
monoclonal antibody in formalin-fixed breast tumors. Lab Invest 1988, 58: $346-353$

26 Hiort OP, Kwan WL \& DeLellis RA. Immunohistochemistry of estrogen receptor protein in paraffin sections. Effects of enzymatic pretreatment and cobalt chloride intensification. Am J Clin Pathol 1988, 90:559-563

27 Said J \& Shintaku IP. Detection of estrogen receptors with monoctonal antiboclies in paraffin sections. Am J Clin Pathol 1988, 90: 120 (letter)

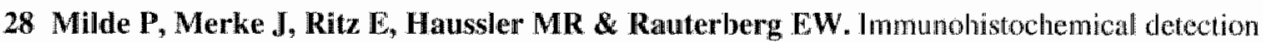
of 1,25-dihydroxyvitamin $\mathrm{D}_{3}$ receptors and estrogen receptors by monoclonal antibodies: comparison of four immunoperoxidase methods. J Histochem Cytochem 1989, 37: $1609-1617$ 


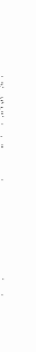

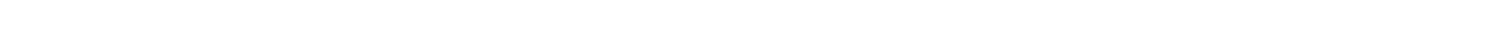

.

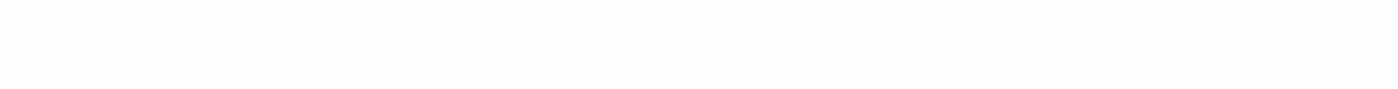
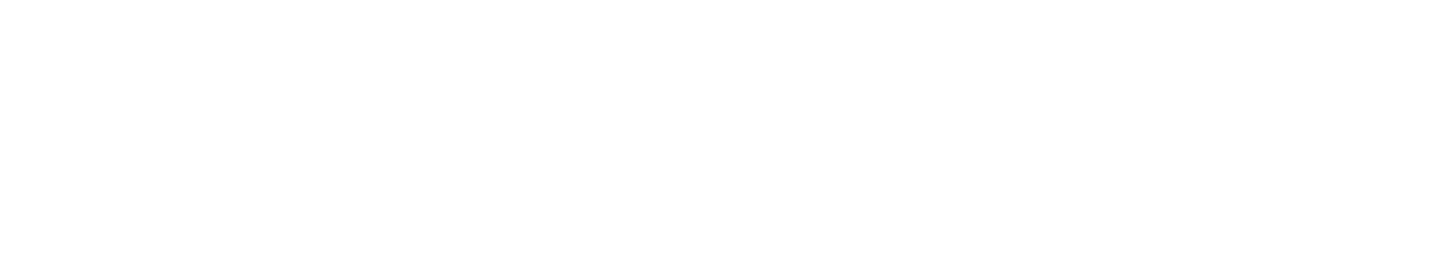
CHAPTER 4

\section{Immunocytochemical analyis of oestrogen and progesterone receptors in the normal human uterus throughout the menstrual cycle and after menopause*}

Snijders MP, De Goeij AF, Debets - Te Baerts MJ, Rousch MJ, Koudstaal Joh \& Bosman FT. Journal of Reproduction \& Fertility 1992, 94: $361-369$ 


\section{Summary}

To obtain more insight into the relationship between cyclic and regional changes in steroid receptor expression and function-related changes in the various cell types of the normal human uterus, an immunocytochemical study was performed on paraffin sections. The distribution and intensity of immunostaining for oestrogen (OR) and progesterone receptor (PR) in the various cell types were semiquantitatively scored. The data were statistically compared for the different phases of the menstrual cycle and postmenopause, and for the different regions of the corpus and (endo)cervix uteri. During the menstrual cycle, significant changes in OR score were observed in glandular and stromall cells of endometrium basalis and functionalis and smooth muscle cells of the myometrium. In all cell types, OR expression reached a maximum in the late proliferative phase. During the early secretory phase, OR staining declined sharply in stromal and smooth muscle cells, whereas, in glandular epithelium OR expression decreased more gradually. During mid and late secretory phases, an increase in OR staining was also observed in predecidualizing stromal cells and smooth muscle cells. PR numbers changed significantly in glandular epithelium but not in stromal and smooth muscle cells. Glandular PR expression reached a maximum in the early secretory phase and was then drastically reduced. During mid and late secretory phases, stromal cells were moderately stained for PR in contrast to epithelial gland cells which showed no or very weak staining. No regional variations in steroid receptor distribution in endometrium and myometrium were found. The results are discussed with respect to literature reports on concentration of steroid hormones and steroid-converting enzymes in tissue and on production of paracrine factors. A different expression of steroid receptors in epithelial and stromal cells is indicated, suggesting autocrine and/or paracrine regulation of cyclic functional and morphological changes in these cell types.

\section{Introduction}

The cyclic process of proliferation, secretory differentiation, degeneration, and regeneration in premenopausal endometrium is controlled by oestrogens and progestogens, and is mediated through binding to their specific receptors. The oestrogen (OR) and progesterone receptor (PR) concentrations in endometrium vary with the phases of the menstrual cycle $(1,2)$, but their relationship to cyclic changes in histomorphology and hormonally modulated tissue factors has not been extensively studied. There is some evidence that these changes reflect functional processes resulting, at least in part, from interactions between uterine cell types (3). Differentiation and functional development of epithelium are suggested to occur by interaction with stromal cells (4-6). Recent reports on the endocrinology of perinidatory endometrium (7-10) have emphasized the involvement of local steroid hormones in 
predecidualization of the endometrium, enabling the blastocyste to implant. We assume that the presence of steroid receptors is closely related to occurence of autocrine and paracrine processes which are responsive to oestrogens and progestogens.

Biochemical ligand-binding studies that require tissue homogenization preclude assessment of steroid receptor content in individual cells. Immunocytochemical techniques using monoclonal antibodies permit visualization and semiquantitation of $\mathrm{OR}$ and $\mathrm{PR}$ at the cellular level (11-14). Distinctive variations in receptor staining in the functionalis layer of the endometrium have been reported to occur throughout the menstrual cycle. OR and PR expression in glandular and stromal cells were at a maximum during the late proliferative and early secretory phases and decreased dissynchronously towards menstruation (15-17). These studies were performed on frozen sections and statistical analysis of receptor data to test the significance of the observed changes was not performed. Regional distribution of PR in the corpus and (endo)cervix uteri was not studied. OR and PR levels have been reported to vary according to the topography of the human uterus. A steep concentration gradient of OR and PR from the fundal to the cervical region was found by radiochemical analysis in several studies $(2,18)$.

The purpose of this study was to investigate the hormonal interrelationship of mesenchymal and epithelial cells in the human uterus by assessing steroid receptor expression and comparing it with cyclic changes in histomorphology and functional activities. To this end, distribution and intensity of OR and PR staining were semiquantitatively scored in the various cell types of the functional and basal layers of the uterus by the use of paraffin-embedded sections (19). The results were statistically analysed for the different phases of the menstrual cycle and postmenopause and for the different regions of corpus and (endo)cervix uteri.

\section{Materials and methods}

\section{Uterine tissue samples}

All patients taking part in the study had undergone hysterectomy (at the De Wever Hospital Heerlen), for complaints that indicated prolonged (essential menorrhagia, $\mathrm{n}=18$ ) or painful menstrual bleeding (dysmenorrhoea, $\mathrm{n}=8$ ) and uterine descensus $(n=9)$. Details on menstrual history, date of last menstrual period, previous hormonal therapy and gynaecologic surgery were recorded. All 30 premenopausal women were between 29 and 46 years of age and had a regular menstrual cycle; five postmenopausal women were between 51 and 66 years of age. None of the patients had a history of exogenous hormonal therapy or distortion of the endometrial cavity (curettage, intra-uterine device etc.) for at least two cycles before surgery. Immediately after surgery, the removed uteri were opened. Two samples including endometrium 
and underlying myometrium were obtained from each of the following regions: midfundus (A), corpus (B), isthmus (C) and (endo)cervix. One specimen was fixed in buffered formaldehyde (3.7\%) and processed routinely for paraffin embedding; the other was frozen immediately and stored at $-70^{\circ} \mathrm{C}$.

None of the uteri revealed histopathological abnormalities. The endometrial dating criteria (as described by Noyes et al. $\{20\}$ ) were used to assess the phase of the menstrual cycle in routinely haematoxylin-eosin stained sections of the midfundus region. The histological appearance of the endometrium was classified as 1 : menstruation (days 1-5), II: early proliferative (days 6-9), III: late proliferative (days 10-14), IV: early secretory (days 15-18), V: midsecretory (days 19-22), VI: late secretory (days 23-28) or VII: postmenopausal. Only specimens with a histological appearance that agreed with the age and date of last menstrual period were included. Five representative uteri were selected for each phase of the menstrual cycle.

\section{Immunostaining}

Steroid receptor immunocytochemistry was performed on paraffin-embedded sections as previously reported (19). In summary, after mounting, deparaffination and rehydration, the sections to be stained for $\mathrm{OR}$ were enzymatically digested with $0.1 \%$ bovine pancreatic trypsin in $0.1 \% \mathrm{CaCl}_{2}$-solution $(\mathrm{pH}=7.8)$ at $37^{\circ} \mathrm{C}$ during $30 \mathrm{~min}$. After incubation with the primary rat anti-OR antibody (gift from Abbott Labotatories, The Netherlands; undiluted; overnight at room temperature $=\mathrm{RT}$ ), the sections were incubated with biotinylated sheep anti-rat immunoglobulin (Amersham, UK; $1: 200 ; 2 \mathrm{~h}, \mathrm{RT}$ ) followed by avidin-biotin peroxidase complex (ABC, Vector Laboratories, USA; 1:200; $2 \mathrm{~h}, \mathrm{RT}$ ).

For PR-immunostaining the sections were incubated with mouse anti-PR antibody (mPR1, ITK Diagnostics, The Netherlands; 1:800; overnight at $4^{\circ} \mathrm{C}$ ), followed by biotinylated sheep anti-mouse immunoglobulin (Amersham; 1:200;90 min, RT) and peroxidase-labelled streptavidin (ITK Diagnostics; $1: 1000 ; 90 \mathrm{~min}, \mathrm{RT}$ ).

As a negative control, adjacent sections were stained according to the same procedures but with normal rat IgG (ITK Diagnostics; undiluted; overnight, RT) instead of rat anti-OR antibody, and non-immune mouse IgG (ITK Diagnostics; 1:800; overnight at $4^{\circ} \mathrm{C}$ ) instead of mouse anti-PR antibody. Sections of OR and PR positive human mammary carcinomas and/or rabbit uterus served as positive controls in every staining procedure. All sections were counterstained with Harris' haematoxylin and mounted in Entellan (Merck, Germany).

$O R$ and $P R$ immunocytochemistry on paraffin sections was validated in an earlier study comparing paraffin and cryostat sections obtained from 35 adjacent uterine samples. Highly significant correlations for both $\mathrm{OR}(\mathrm{r}=0.96, \mathrm{P}<0.00001)$ and $P R$ $(\mathrm{r}=0.96, \mathrm{P}<0.00001)$ scores in smooth muscle, glandular and stromal cells were found by linear regression analysis (19). The intensity and distribution of specific staining were evaluated visually using a modification of the semiquantitative analysis of McCarty et al. (11), as follows: 
receptor score $=\sum_{i=0}^{i=4} P(i) \times i$

where $\mathrm{i}$ is intensity of staining from 0 (no staining) to 4 (very intense staining) and $P(i)$ is percentage of stained cells in category $i(0-100 \%)$. Classification of staining intensity was assessed on at least three separate cohorts of 100 cells in different high power ( $\mathrm{x} 400$ ) fields, allowing assessment of heterogeneity in cell receptor content. The final receptor score was obtained by calculating the mean of the cohorts. Intraobserver ( $\mathrm{r}=0.96, \mathrm{P}<0.00001$ ) and interobserver (for OR: $\mathrm{r}=0.84, \mathrm{P}<0.0001$; for PR: $r=0.93, P<0.00001$ ) differences for our scoring methods have been reported previously $(13,14)$.

\section{Statistical analysis}

Histological appearance combined with recorded last menstrual period, were stratified at menstrual cycle intervals I-VI and regions A, B and C. These data were entered into a computer data base (Statgraphics software) for analysis. One-way analysis of variance was used to examine the relationships between menstrual cycle phase or uterine region and receptor scores. These tests compared the six menstrual cycle phases or three different regions simultaneously; a significant result in each analysis meant that differences between menstrual cycle phases or differing uterine regions in levels of $O R$ and PR scores could not be attributed to chance. A P value of less than 0.05 was considered significant.

\section{Results}

Staining for OR and PR was seen exclusively in nuclei of myometrial, stromal, and glandular cells and receptor staining was not observed in connective tissue or vascular wall elements. Immunostaining was not observed in negative controls. In endometrium, OR and PR staining was heterogeneously distributed in glandular epithelial and stromal cells. Semiquantitative immunocytochemical receptor scores were obtained for the main cell types in the uterus i.e. smooth muscle cells of the myometrium and glandular epithelial and stromal cells of endometrium basalis and functionalis. For each menstrual cycle phase (I-VI) and postmenopause (VII), OR and PR staining were evaluated in the different cell types of five representative midfundus and (endo)cervix specimens. The results including $\mathrm{P}$ values of one-way analysis of variance, are presented in Figs 1 and 2. 

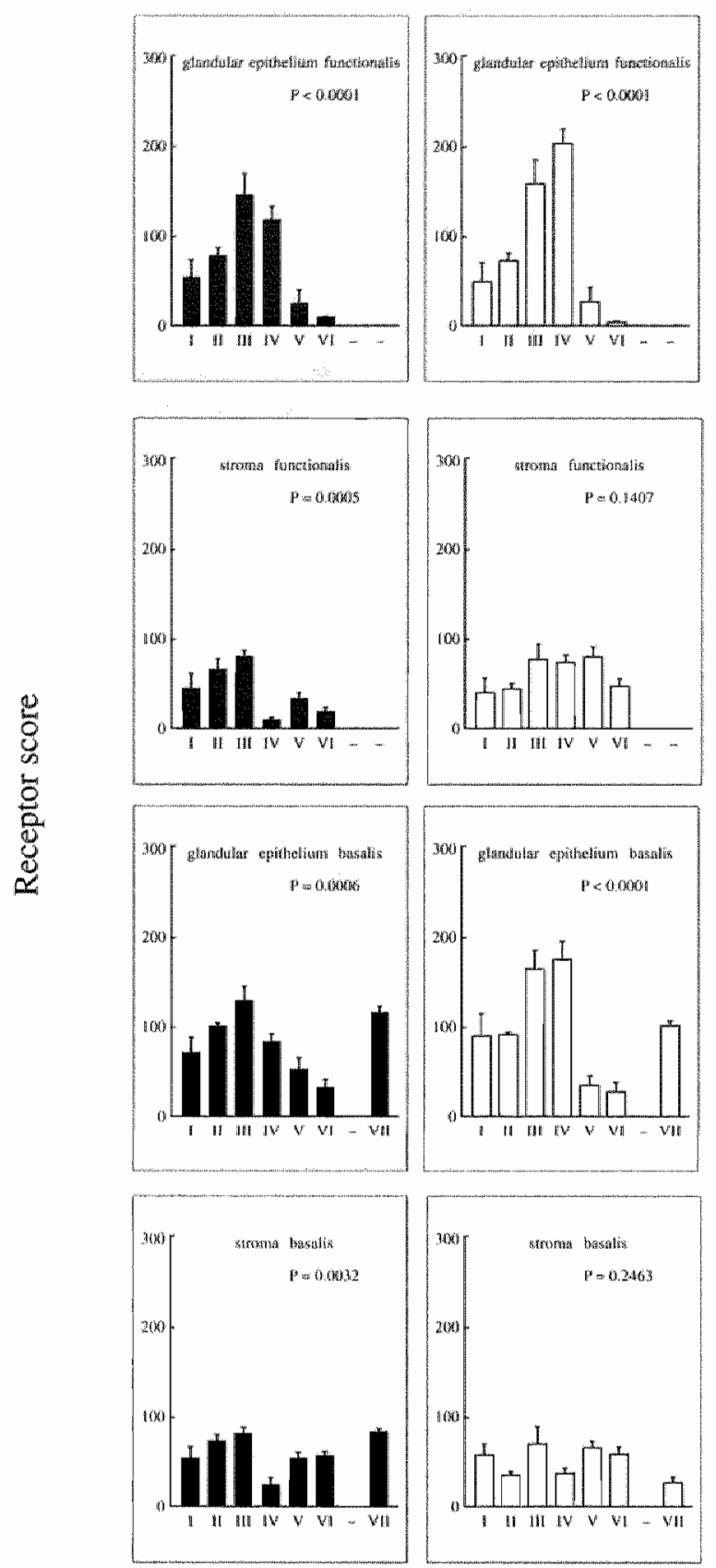

\section{Menstrual cycle phase}

Fig. 1. Immanocyochemical OR (closed bars) and PR (open bars) scores (mean $+S E M, n=5$ ) in glandular epithelium and stroma of endometrium basalis and functionalis during menstrual cycle phases I-VI and after menopause (VII) 


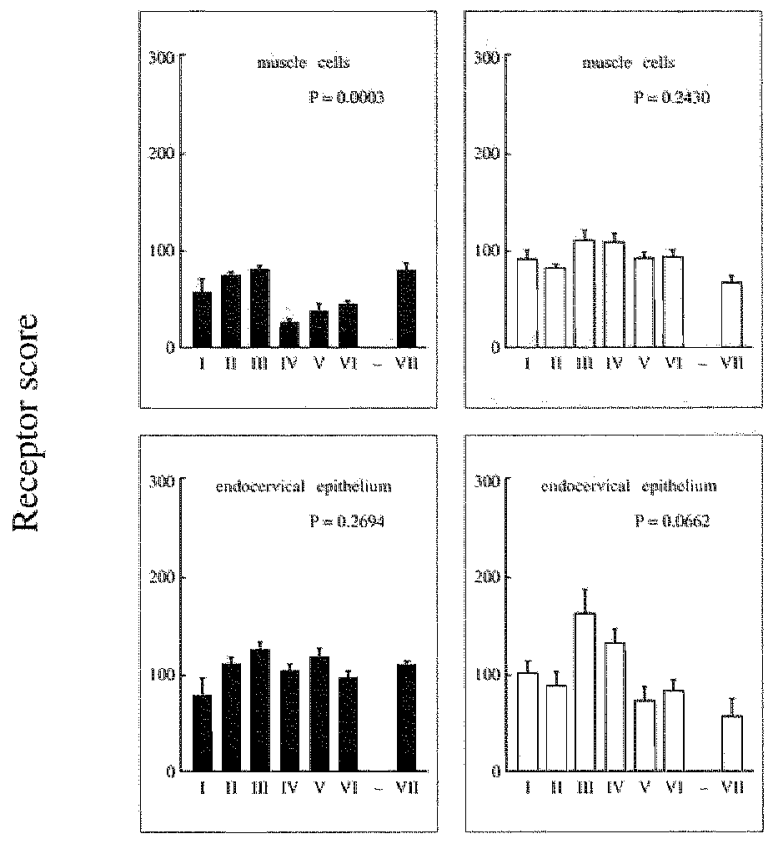

Menstrual cycle phase

Fig. 2. Immunocytochemical OR (closed bars) and PR (open bars) scores (mean $+S E M, n=5$ ) in smooth muscle cells of the myometrium and glandular epithelium of the endocervix during menstrual cycle phases 1-VI and after menopanse (VII)

Expression of OR reached a maximum in the late proliferative phase in all cell types of the uterus. Stromal and smooth muscle cells showed less intensive staining than glandular epithelial cells as shown in Fig. 3a. In the early secretory phase, OR staining declined sharply in stromal and smooth muscle cells, whereas in glandular epithelium OR expression decreased more gradually. During the mid and late secretory phases, the OR content of smooth muscle cells and of predecidualizing stromal cells around the spiral arterioles and in the subluminal area increased slightly. After menopause, OR expression was pronounced in myometrial smooth muscle cells and in glandular epithelial and stromal cells of the compact atrophic endometrium.

PR expression of glandular epithelial cells of endometrium basalis and functionalis was strong during the proliferative phases, reaching a maximum in the late proliferative and early secretory phases. In the mid and late secretory phases, PR expression in the glandular epithelium was reduced considerably, with few glandular epithelial cells in the basalis showing PR staining. Stromal cells in basal and functional endometrium showed minor (statistically nonsignificant) fluctuations during the various phases of the menstrual cycle. During the mid and late secretory phases, stromal cells that were moderately stained for PR contrasted with adjacent epithelial gland cells which showed little or no staining (Fig. 3b). More specifically, 

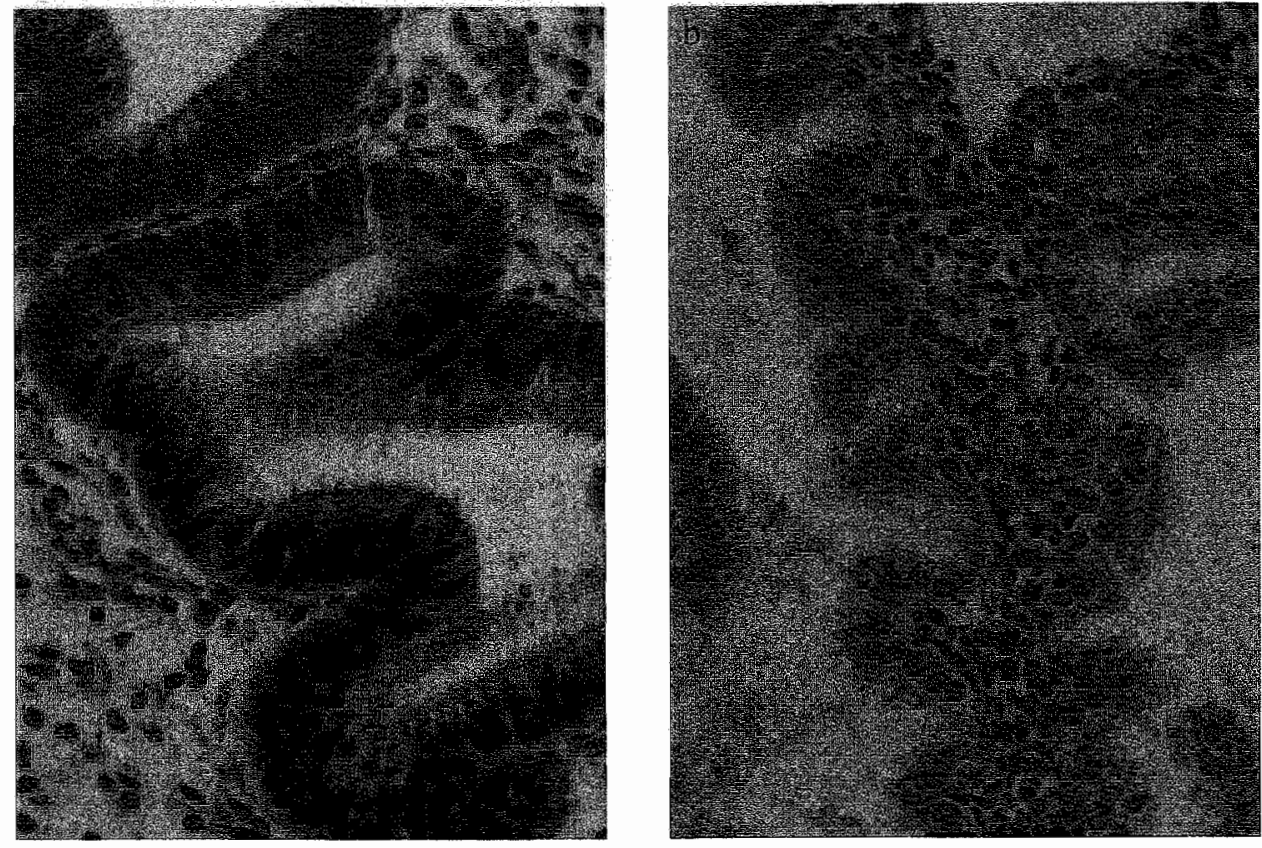

Fig. 3. Immunostaining of steroid receprors

a. Strong OR staining in glandular epithelium contrasting with moderately stained stroma in late proliferative (III) endomerrium (magn. *400)

b. Strong PR staining in stromal cells in contrast to no/weak staining in glandular epithelial cells in midsecretory ( $V$ ) endometriun (magn. ${ }^{*} 320$ )

predecidualizing stromal cells in the subluminal region showed moderate to strong PR expression. Smooth muscle cells showed consistently strong nuclear PR staining throughout the menstrual cycle. After menopause, PR expression in the human uterus was characterized by moderate staining of smooth muscle cells and glandular epithelium, but only weak staining of stromal cells.

In the ectocervix, the basal and to a lesser extent the parabasal cells of the squamous epithelium were moderately stained for OR during the proliferative phases. A shift in OR expression to the parabasal and intermediate cell layers was observed during the secretory phases. The superficial cell layers were unstained. Postmenopausal samples revealed a moderate level of OR expression in basal, parabasal and intermediate cells. Superficial cells were again not stained. PR expression was absent or very weak in the squamous epithelium during all menstrual cycle phases and after menopause (data not shown).

In the endocervix, mucus-secreting epithelial cells showed strong OR staining during all phases of the menstrual cycle (see Fig. 2). PR expression in these cells tended to reach a maximum in the late proliferative phase but this was not statistically significant $(P=0.06)$. After menopause, strong $O R$ and moderate $P R$ 
staining of glandular cells in the endocerwix was observed. Cervical stromal and smooth muscle cells showed a fairly constant expression of OR and PR at at moderate concentration during the different menstrual cycle phases and after menopause (data not shown).

The mean OR and PR scores of the various cell types were compared for uterine midfundus, corpus and isthmus uteri regions. No significant differences in OR and PR scores between the different uterine sites were observed for any menstrual cycle phase nor in postmenopause (data not shown).

\section{Discussion}

Immunocytochemical analysis showed the presence of steroid receptors in epithelial and mesenchymal cells in the uterus, indicating that these cells respond to oestrogen and progestogen. Semiquantitative scoring of immunocytochemical receptor staining correlates significantly with radiochemical assay $(11,13)$. The use of cryostat sections is validated for steroid receptor immunocytochemistry but appears less suitable for adequate interpretation of menstrual cycle phase-related histomorphology. The highly significant correlations between immunocytochemical OR and PR scores in paraffin and cryostat sections warrant the use of routinely fixed paraffin-embedded tissues with optimal preservation of histomorphology (19).

During the proliferative phases of the menstrual cycle, endometrial and myometrial oestradiol $\left(E_{2}\right)$ concentrations are high, with a high tissue to plasma ratio (21). $E_{2}$ stimulates DNA synthesis and proliferation and induces the expression of OR and PR $(22,23)$. The observed increase in OR and PR expression in all uterine cell types during the proliferative phases probably results from increased local $\mathrm{E}_{2}$ concentrations.

After ovulation, distinct variations in $\mathrm{OR}$ and PR expression in both basal and functional endometrium were observed, which is in contrast 10 findings of Press et al. (15) and Lessey et al. (17). The significant decrease in OR content in various cell types is consistent with a sharp drop in endometrial and myometrial $\mathrm{E}_{2}$ concentrations (21). It is therefore noteworthy that increasing progesterone concentrations not only directly antagonize $E_{2}$ action but also induce a 10 -fold increase of 173 -hydroxysteroid dehydrogenase, an enzyme which drastically reduces the concentration of $\mathrm{E}_{2}$ and $\mathrm{OR}$ (23). The persistence of PR in glandular epithelium during the early secretory phase is consistent with progesterone action, which inhibits mitosis and stimulates the secretory function of glandular epithelium $(22,24,25)$.

After the early secretory phase, glandular PR concentration is drasticallly reduced; this occurs in parallel with the maximal activity of glandular 200 -hydroxysteroid 
dehydrogenase, an enzyme responsible for conversion of progesterone to the weak progestin 200-dihydroprogesterone (23). However, in contrast to other reports $(15,17)$, a concomitant slight increase in OR content and persistence of PR content in mesenchymal cells were observed. The myometrium retains PR and this is in keeping with the suggestion that progesterone inhibits the contractility of the myometrium in early pregnancy (17). The shift of steroid action in the endometrium from glandular epithelium to stroma is probably related to reported autocrine activation of stromal aromatase and oestrone $\left(\mathrm{E}_{1}\right)$ sulfatase by progestogens and oestrogens (7-9). These enzymes utilize circulating androgens and $E_{1}$ sulfate as substrates and lead to oestrogenic stimulation of stromal cells, which is reflected by preferential OR and PR expression. Meanwhile, these cells show a conversion of fibroblast-like cells into rounder and larger (pre)decidual cells which produce mediators that are related to embryo implantation and maintenance of early pregnancy $(10,26)$.

In the late secretory phase, the major secretory protein of the glandular epithelium, human pregnancy-associated endometrial $\alpha_{2}$-globulin $\left(\alpha_{2}-\mathrm{PEG}\right)$ is maximally produced $(27)$. Our observations and those of others $(10,24)$ studying interactions between stromal and epithelial cells, suggest that glandular secretion during secretory phases is, at least in part, mediated through paracrine actions of stromal cells.

During menstruation, strong but heterogeneous OR staining of glandular and stronal cells of the endometrium basalis is thought to be localized in the so-called progenitor cells which are responsible for regenerative growth of basal endometrium starting from the third or fourth day of the cycle $(15,22)$.

After menopause, strong OR immunostaining in all uterine cell types is consistent with a positive tissue to plasma $\mathrm{E}_{2}$ ratio (28). Moderate $\mathrm{PR}$ staining that is predominantly localized in glandular epithelium again shows a differential distribution of steroid receptors over epithelial and mesenchymal cell types in the postmenopausal uterus.

No significant gradients in regional $\mathrm{OR}$ and $\mathrm{PR}$ expression in the various cell types over the length of the uterine cavity are observed during the menstrual cycle and after the menopause. Probably the samples assayed in the ligand-binding studies that reported steep concentration gradients $(2,18)$, included not only uterine mucosa but also underlying tissues, which might result in an apparent reduction in OR and PR content in the lower uterine segments.

Physiological preovulatory endocervical mucus secretion might be directly related to an adequate upregulation of receptor content. It is well known from empirical studies that oestrogen treatment increases secretion of cervical mucus. It may be noted that infertile women with poor secretion of cervical mucus may have deficiency in OR and PR in endocervical glands (29). Furthermore, defects in luteal function are considered to be a cause of infertility and can be related to lower steroid receptor content in the endometrium (30). Steroid receptor immunocytochemistry of 
endocervical and endometrial biopsies therefore offers a new approach to the clinical study of infertility.

In conclusion, this study demonstrates a differential $O R$ and PR expression in the epithelial and stromal elements of the uterus throughout the menstrual cycle. The cyclic pattern of steroid receptor expression in the various tissue types appears to be related to recently reported autocrine and paracrine mechanisms involved in embryo implantation and early pregnancy.

\section{Acknowledgements}

We thank Dr. B. Schutte for statistical advice and mrs. G. Tolenaars for expert technical assistance.

\section{References}

1 Tamaya T, Murakami T $\&$ Okada H. Concentrations of steroid receptors in normal human endometrium in relation to the day of the menstrual cycle. Acta Obstet Gynecol Scand 1986 , 65: $195-198$

2 Godoreski IG, Bahary CM, Lunenfeld B, Beery R \& Geier A. Distribution of total estradiol receptor levels in various segments and tissues of the normal and pathological human uterus. Gynecol Obstet Invest 1988, 26: 296 - 301

3 Healy DL \& Hodgen GD. The endocrinology of human endometrium. Obstet Gyn Surv 1983 , 38: $509-530$

4 Cunha GR, Chung LW, Shannon JM, Taguchi O \& Fujii H. Homone-induced morphogenesis and growth: role of mesenchymal-epithelial interactions. Recent Prog Hormone Res 1983, 39:559-599

5 Cooke PS, Uchima FA, Fujii DK, Bern HA \& Cunha GR. Restowation of nomal morphology and estrogen responsiveness in cultured vaginal and uterine epithelia transplanted with stroma. Proc Natl Acad Sci USA 1986, 83:2109-2113

6 Roberts DK, Walker NJ \& Lavia LA. Ultrastructural evidence of" stromal/ epithelial interactions in the human endometrial cycle. Am J Obster Gynecol 1988, 158: 854 - 861

7 Tseng L, Mazella $J \&$ Sun B. Modulation of aromatase activity in human endometrial stromal cells by steroids, tamoxifen and RU 486. Endocrinology $1986,118: 1312=1318$

8 Randolph JF Jr, Peegel $\mathbf{H}_{3}$ Ansbacher $\mathbf{R}$ \& Menon KM. In witro induction of prolactin production and aromatase actiwity by gonadall steroids exclusiwely in the stroma of separated proliferative endometrium. Am J Obsiet Gynecol 1990, 162:1109-1114

9 Benedetto MT, Tabanelli S \& Gurpide E. Estrone sulfate sulfatase activity is increased during in vitro decidualization of stromal cells from human endometrium. I Clin Endocrinol Metab 1990, 70: 342 - 345 
10 Aleotay AA, Harper MJ, Schenken $\mathbb{R S}$ \& Hanahan DJ. Paracrine interactions between platelet-activating factor and prostaglandins in hormonally-treated human luteal phase endometrium. I Reprod Fert 1991, 91:301-312

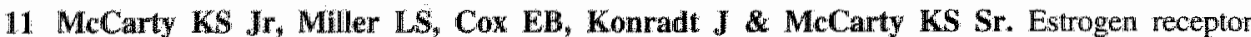
analyses: correlation of biochemical and immunohistochemical methods using monoclonal antireceptor antibodies. Arch Pathol Lab Med 1985, 109: 716-721

12. Press MF Greene GL Immunocytochemical localization of estrogen and progesterone receptors. In: Advances in Immunohistochemistry. Delellis $R A$, ed. New York, Raven Press $1988: 341-361$

13 Scheres HM, De Goelj AF, Rousch MJ et all. Estrogen receptor quantification in human breast cancer: radiochemical assay on cytosol and cryostat sections compared with semiquantitative immunocytochemical analysiss. J Clin Pathol 1988, 41:623-632

14 Snijders MP, De Goeij AF, Koudstaal Joh et al. Is immunohistochemical analysis of oestrogen and progesterone receptors in endometrial carcinoma superior to the radioligand binding assay ? I Pathol 1990, 161:129-135

15 Press MF, Nousek-Goebl NA, Bur M \& Greene GL. Estrogen receptor localization in the female genital tract. Am J Pathol 1986, 123: 280 - 292

16 Press MF, Udove IA \& Greene GL. Progesterone receptor distribution in the human endometrium. Analysis using monoclonal antibodies to the human progesterone receptor. Am I Pathol 1988, 131:112-124

17 Lessey BA, Killiam AP, Metzger DA, Haney AF, Greene GL \& McCarty KS. Immunohistochemical analysis of uterine estrogen and progesterone receptors throughout the menstrual cycle. J Clin Endocrinol Metab 1988, 67:334 - 340

18 Vollmer G, Kniewe $M_{*}$ Meyn U, Tuchel L, Armholdt H \& Knuppen R. Spatial and molecular aspects of estrogen and progesterone receptor expression in human uteri and uterine carcinomas. J Steroid Biochem 1990, 36: 43-55

19 Snijders M, Theunissen P, Debets - Te Baerts M \& Koudstaal Joh. Immunhistochemischer Nachweis won Östrogen- und Progesteronrezeptoren in Paraffinschnitten. Pathologe 1990, 11: $236-239$

20 Noyes RW, Hertig AT \& Rock J. Dating the endometrial biopsy. Fertil Steril 1950, 1: 3 - 10

21 Alsbach GP, Franck ER, Poortman J \& Thijssen JH. Subcellar distribution of estradiol and estrone in human endometrium and myometrium during the menstrual cycle. Contraception $1983,27: 409-421$.

22 Ferenczy A, Bertrand G \& Gelfand MM. Proliferation kinetics of human endometrium during the normal menstrual cycle. Am J Obstet Gynecol 1979, 133:859-867

23 Tseng $L$. Physiologic changes in binding and metabolism of estradiol and progesterone in human endometrium during the menstrual cycle. Obstet Gynecol Ann 1979, 8: $1-17$

24 Bell SC, Patell SR, Kirwan PH \& Drife JO. Protein synthesis and secretion by the human endometrium during the menstrual cycle and the effect of progesterone in vitro. J Reprod Fert $1986,77: 221-231$

25 Smith RA, Seif MW, Rogers AW at al. The endometrial cycle: the expression of a secretory component correlated with the luteinizing hormone peak. Hum Reprod 1989, 4: 236-242

26 Waites GT, James RF \& Bell SC. Immunohistological localization of the human endometrial secretory protein 'pregnancy-asssociated endonetrial $\alpha_{1}$-globulin' $\left(\alpha_{1}\right.$-PEG), an insulin-like growth factor binding protein, during the menstrual cycle. J Clin Endocrinol Metab 1988, 67: $1100-1104$ 
27 Waites GT, Wood PL \& Bell SC. Immunohistological localization of human endometrial secretory protein, "pregnancy-associated endometrial $\alpha_{2}$-globulin' $\left(\alpha_{2} \text {-PBG }\right)_{\text {, during the }}$ menstrual cycle. J Reprod Fert 1988, 82: 665 - 672

28 Vermeulen-Meäners C, Benedek Jaszman LJ, Haspels AA, Poortman J \& Thijssen JH. The endogenous concentration of estradiol and estrone in normal human postmenopausal endometriam. J Steroid Biochem 1984, 21: 607 - 612

29 Abuzeid MI, Wiebe RH, Aksel S, Shepherd J \& Yeoman RR. Evidence for a possible cytosol estrogen receptor deficiency in endocervical glands of infertile women with poor cervical mucus. Fertil Steril 1986, 47: $101-107$

30 Jacobs MH, Balasch J, Gonzalez-Merlo JM et al. Endometrial cytosolic and nuclear progesterone receptors in the luteal phase defect. IClin Endocrinol Metab 1987, 64: 472 - 475 


.

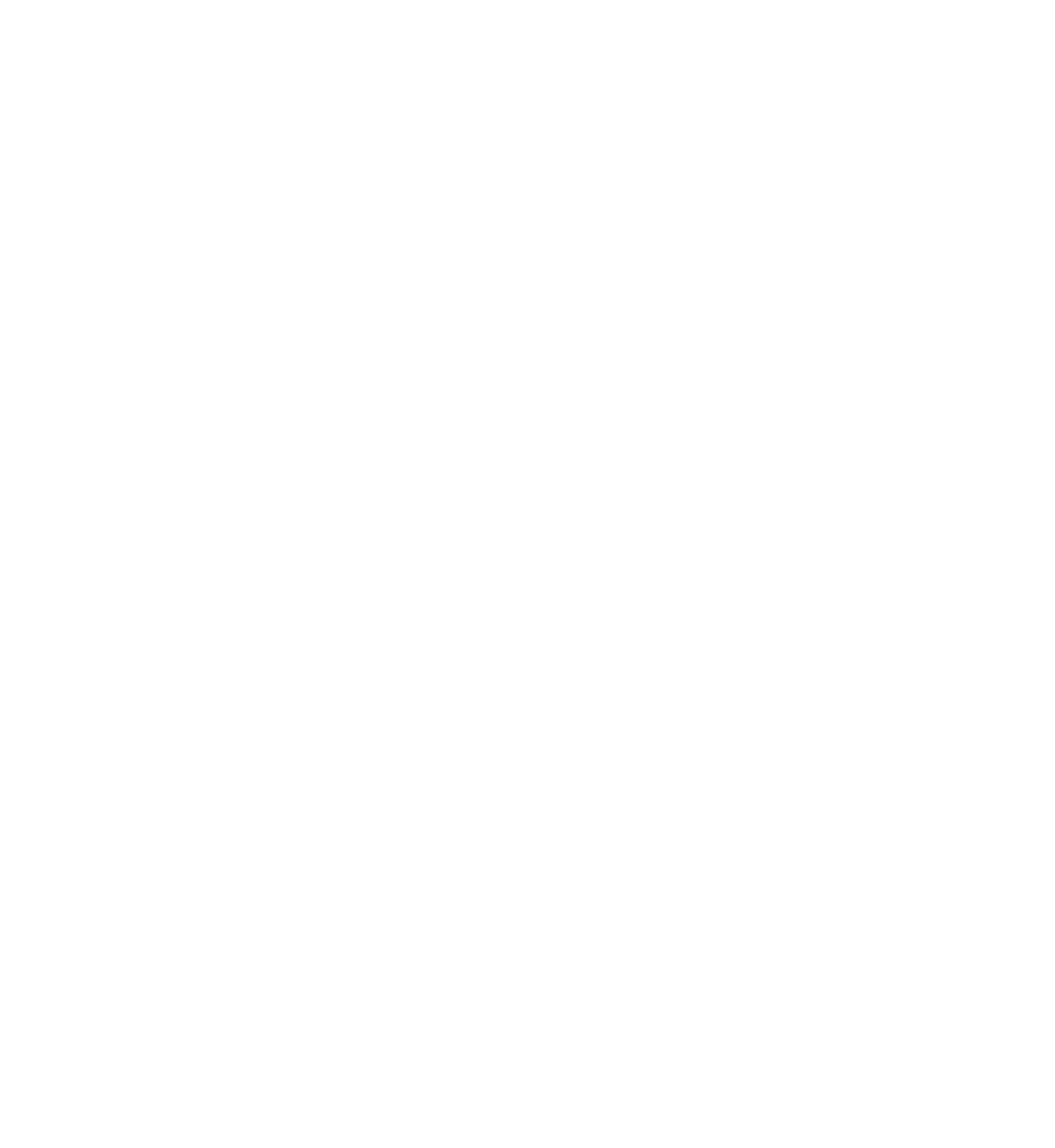




\section{CHAPTER 5}

\section{Oestrogen and progesterone receptor immunocytochemistry in human hyperplastic and neoplastic endometrium*}

* Snijders MP, De Groeij AF, Koudstaal Joh, Thunnissen EB, de Haan 』\& Bosman FT. Journal of Pathology 1992, 166: 171-177 


\section{Summary}

Proliferative disorders of the endometrium may be associated with autocrine and paracrine actions between stromal and epithelial cells. To determine whether the stromal-epithelial relation with respect to oestrogen receptor (OR) and progesterone receptor (PR) is disturbed in (pre)malignant endometrium, immunocytochemical OR and PR expression was quantitated by computerized image analysis. This was studied in the stromal and epithelial cells of endometrial specimens diagnosed as hyperplasia $(n=14)$, atypical hyperplasia $(n=16)$ and adenocarcinoma $(n=33)$. Paraffin sections were used for optimal preservation of histomorphology. A progressive loss of $O R$ and $P R$ content occurred with increasing malignant transformation. Stromal cells in atypical hyperplasia $(P=0.0007)$ and well differentiated adenocarcinoma $(P=0.0008)$ exhibited a relative loss of $P R$ content as compared to epithelial cells $(P=0.036$ and $P=0.17$, respectively). In atypical hyperplasia, the decrease in stromal PR content was not in parallel with persistent stromal OR immunostaining. Furthermore, stromal PR expression in atypical hyperplasia was significantly $(\mathrm{P}=0.004)$ lower than in the surrounding hyperplasia, whereas the stromal OR staining as well as the epithelial OR and PR staining did not differ significantly. These observations may reflect a disturbance in hormonal interrelationships between endometrial cells in the development of endometrial neoplasia, indicating that stroma may modulate epithelial growth by paracrine mechanisms.

\section{Introduction}

Oestrogens and progestogens are known to modulate endometrial proliferation and differentiation via their receptors. Several studies have indicated that prolonged oestrogenic stimulation, unopposed by progestogens, may promote the development of endometrial hyperplasia, atypical hyperplasia and adenocarcinoma (1-3). These proliferative disorders vary in biological behaviour, clinical course, and response to endocrine therapy. Most women with hyperplasia do not have a significantly increased risk for developing an endometrial cancer and will respond favourably to progestational therapy $(4,5)$. In contrast, endometrial hyperplasia with cytological atypia often progresses to carcinoma and shows an unfavourable response to progestogens $(4,5)$. When endometrial adenocarcinoma has developed, the proliferative character of the disorder has become irreversible. For histopathological evaluation of endometrial (atypical) hyperplasia, a marker that could better identify patients at increased risk for cancer would be very helpful (6). Furthermore, this marker might be used as a prognostic indicator for progression once adenocarcinoma has developed. In cancer of the breast and endometrium, it has been extensively 
demonstrated that the oestrogen receptor (OR) and progesterone receptor (PR) are useful in providing information relevant for prognosis and response to hormonal therapy (7-11).

Hormone responsiveness of endometrial epithelium has been shown to depend strongly on interaction with the stroma, suggesting autocrine and paracrine action between these cell types $(12,13)$. Stimulated by steroids, the stroma produces growth regulating factors which control epithelial cell differentiation and function (14). Stromal-epithelial interactions increase during the oestrogen-stimulated proliferative phase of the menstrual cycle, resulting in invasion of the epithelial basement membrane, as has recently been shown in an ultrastructural studly by Roberts et al. (15). We assume that stromal-epithelial interactions may also play a role in the formation of proliferative disorders of the endometrium.

The purpose of the present study was to determine whether the stromal-epithelial relation with respect to $\mathrm{OR}$ and $\mathrm{PR}$ expression is disturbed in (pre)malignant endometrium. To this end, the immunocytochemical OR and PR expression was quantitated in stromal and epithelial cells of biopsies diagnosed as endometrial hyperplasia, atypical hyperplasia, and adenocarcinoma. Also, the histomorphology and receptor content of the endometrium surrounding atypical hyperplasias were evaluated. Paraffin sections were used for optimal preservation of histomorphology $(16,17)$ and computerized image analysis $(18)$ was used to quantitate steroid receptor immunoreactivity.

\section{Materials and methods}

\section{Tissue samples}

A total of 63 formalin-fixed endometrial specimens was studied, which were obtained consecutively by hysterectomy or diagnostic curettage (at the De Wever Hospital Heerlen), between 1987 and 1990. None of the patients had been treated with progestogens prior to diagnosis. The age of the patients and the histopathological diagnosis are presented in Table 1. Hyperplasia was classified according to the histopathological criteria described by Kurman and Norris (1). Briefly, hyperplastic endometria contained architectural alterations of endometrial glands ranging from minimal to complex. By definition, the glandular lining epithelium was devoid of cytological atypia. Hyperplastic lesions in which the lining epithelium displayed nuclear atypia were classified as atypical hyperplasia. Patients diagnosed with atypical hyperplasia by curettage all underwent hysterectomy within six weeks after diagnosis. Endometrial adenocarcinomas were graded by two pathologists by consensus, according to the revised FIGO definitions (19). 
Table 1. Diagnosis and age distribution of patients.

\begin{tabular}{lccc}
\hline $\begin{array}{l}\text { histopathological } \\
\text { diagnosis }\end{array}$ & $n$ & $\begin{array}{c}\text { Mean age } \\
\text { (years) }\end{array}$ & $\begin{array}{c}\text { Range } \\
\text { (years) }\end{array}$ \\
\hline & 14 & 50 & $38-77$ \\
hyperplasia & 16 & 62 & $36-83$ \\
atypical hyperplasia & 10 & 64 & $37-78$ \\
adenocarcinoma grade I & 16 & 60 & $41-76$ \\
adenocarcinoma grade II & 7 & 70 & $66-82$ \\
adenocarcinoma grade III & & & \\
\hline
\end{tabular}

\section{Immunocytochemical staining}

Steroid receptor immunocytochemistry was performed on sections from $3.7 \%$ formalin-fixed, paraffin-embedded tissues as described earlier $(17,20)$. Briefly, before $\mathrm{OR}$ staining the sections were enzymatically digested with $0.1 \%$ bovine pancreatic trypsin in $0.1 \% \mathrm{CaCl}_{2}$-solution ( $\mathrm{pH} 7.8$ ) at $37^{\circ} \mathrm{C}$ for $30 \mathrm{~min}$. After incubation with the primary rat anti-OR (H222 SP $\gamma$ ) monoclonal antibody (ER-ICA kit, gift from Abbott Laboratories, The Netherlands; undiluted; overnight, at room temperature $=\mathrm{RT}$ ), the sections were incubated with biotinylated sheep anti-rat immunoglobulin (Amersham, UK; $1: 200 ; 2 \mathrm{~h}, \mathrm{RT}$ ) followed by avidin-biotin peroxidase complex (ABC, Vector Laboratories, USA; $1: 200 ; 2 \mathrm{~h}$, RT).

For PR, the sections were incubated with mouse anti-PR antibody (mPR1, from ITK Diagnostics, The Netherlands; 1:800; overnight at $4^{\circ} \mathrm{C}$ ), followed by biotinylated sheep anti-mouse immunoglobulin (Amersham; $1: 200 ; 90 \mathrm{~min}, \mathrm{RT}$ ) and peroxidaselabelled streptavidin (ITK Diagnostics; 1:1000; $90 \mathrm{~min}, \mathrm{RT}$ ).

Finally, the sections were incubated for $7 \mathrm{~min}$ in a substrate solution containing cliaminobenzidine (DAB) with $0.002 \%$ hydrogen peroxide and $1 \mathrm{mM}$ imidazol (Sigma Chemical, USA). The sections were counterstained with methyl green and mounted in Entellan (Merck, Germany). As a negative control, adjacent sections were stained according to the same procedures but with normal rat IgG instead of rat anti-OR antibody and mouse $\operatorname{lgG}$ instead of mouse anti-PR antibody. Sections of OR and PR positive human mammary carcinomas and/or rabbit uterus served as positive controls in every staining procedure.

\section{Computerized image analysis of steroid receptor staining}

Quantification of receptor staining was performed with the Cell Analysis System 200 (CAS 200, from Becton Dickinson, Belgitum) which has two sensors in parallel, digitizing the images at different wavelengths (18). The nuclei were identified by virtue of the green counterstain with the use of a $650-\mathrm{nm}$ filter. The DAB reaction product was measured using a $500-\mathrm{nm}$ filter. Nuclear threshold was set interactively 
set interactively under visual inspection. The antibody threshold discriminating between positive and negative cells was adjusted as described by Bacus et al (18). The percentage positive area (\% Pos. Area) was defined as the number of pixels within nuclei with chromogen intensity at $500 \mathrm{~nm}$ above the control antibody threshold, divided by the total number of nuclear pixels times 100. In each specimen, OR and PR immunoreactivity was subsequently analysed in the epithelial and stromal cell nuclei. In addition, steroid receptor expression was analysed in the hyperplastic endometrial tissue surrounding atypical hyperplasia. If in an area elements other than endometrial stroma or epithelial cells were present, these were: excluded from the measurement.

\section{Statistical analysis}

Using the progressive mean, an approximation of the number of fields to be measured was obtained. Ninety-five \% confidence intervals (c.i.) were calculated for mean results of repeated scorings as described by Altman and Gardner (21). Differences between mean receptor scores in two tissue types were analysed using the (distribution-free) Mann-Whitney $U$ test. A P value of less than 0.05 was considered to be significant.

\section{Results}

Receptor immunoreactivity was heterogeneously distributed in the epithelial cells of hyperplastic and neoplastic endometrium. This was in contrast with the more homogeneous staining of stromal cells, which is illustrated in Fig 1. For reliable receptor quantitation the minimum number of fields to be measured per section had to be determined. Analysis of at least 15 high-power $(x 400)$ fields of endometrial epithelium and of 10 fields of stroma per section yielded a variation in receptor scoring of less than $1 \%$, which was judged to be acceptable. To assess intra-observer variability, 16 specimens were repeatedly analysed by one observer (M.P.S.). Six analyses yielded a mean $95 \%$ c.i. of $\mathrm{x} \pm 9 \%$ (median 7.9 , range $2.5-12.0$ ). These data indicate that computerized image analysis allows objective and reproducible quantitation of steroid receptor expression in stromal and epithelial cells of endometrium.

Receptor expression in epithelium and stroma of hyperplasia (hyp), atypical hyperplasia (atyp hyp) and grade I-III adenocarcinoma (enca $\llbracket-3$ ) of the endometrium is summarized in Fig. 2. Mean OR staining in epithelium and stroma of endometrial atypical hyperplasia did not differ significantly from that in hyperplasia. In well-differentiated adenocarcinoma, stromal OR staining was significantly lower than that in atypical hyperplasia $(\mathrm{P}=0.004)$ and hyperplasia $(\mathrm{P}=0.003)$. OR 

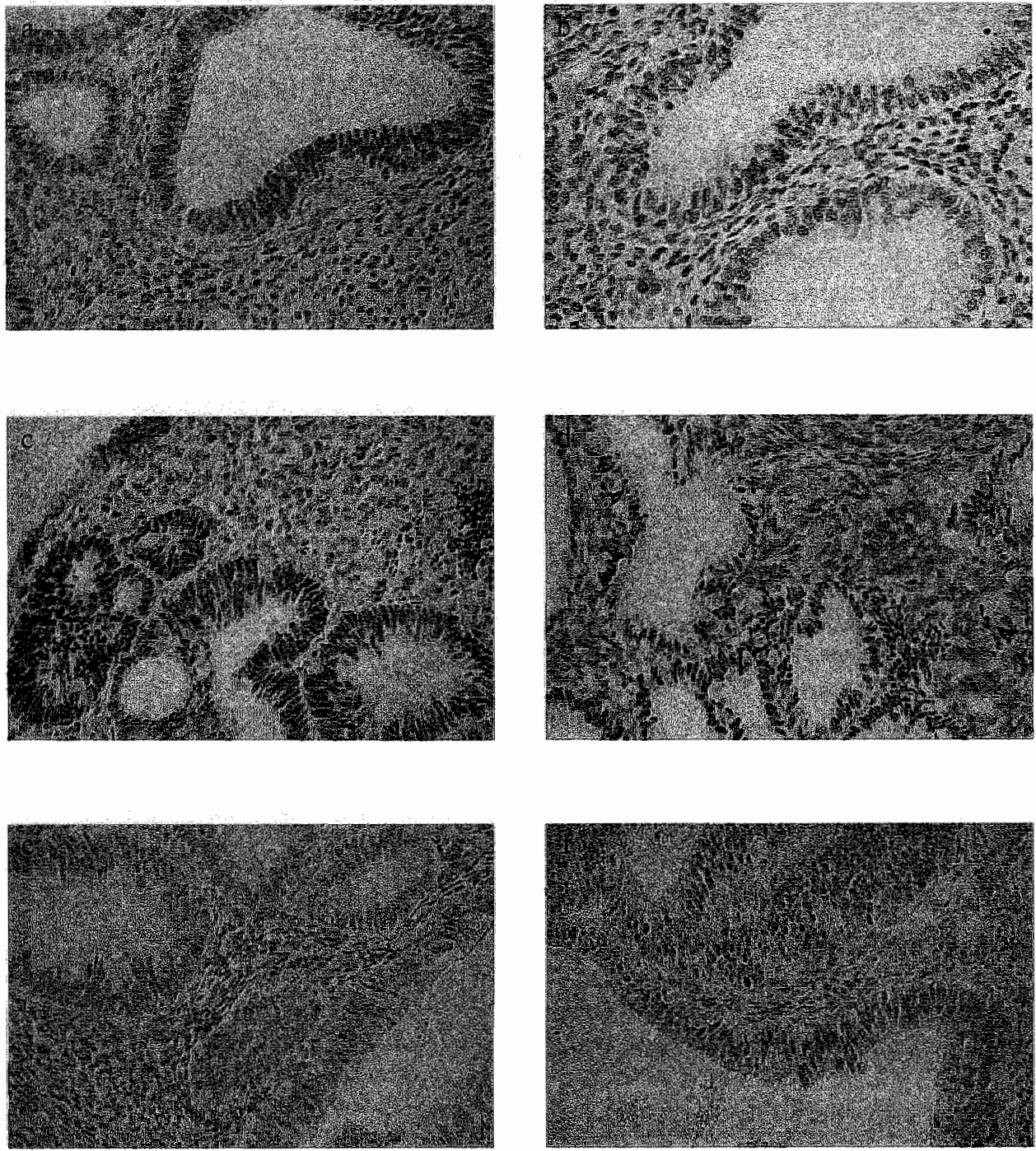

Fig. I. OR and PR immunostaining in proliferative disorders of the endometrium (methyl green counterstain). Hyperplasia: strong $O R(a)$ and PR (b) staining in glandular epithelium contrasting with moderate stromal staining. Atypical hyperplasia: (c) strong OR staining in glandular epitheliwn and moderate sronal staining, and (d) strong PR staining in glandular epithelium. contrasting with weak stronal staining. Well-differentiated adenocarcinoma: (e) moderate OR staining in glandular epithelium contrasting with weak stromal staining, and $(f)$ strong $P R$ staining contrasting with no stromal staining 

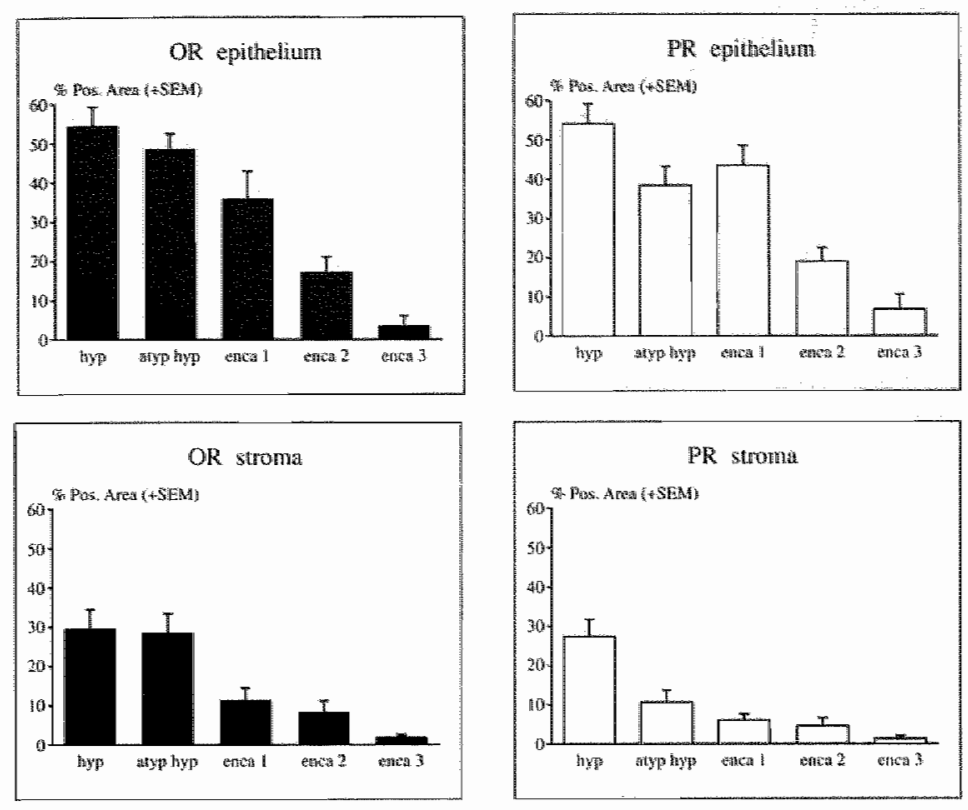

Fig. 2. OR and PR scores (\% POS. Area mean + SEM) in glandular epithelium and stroma of endometrial hyperplasia (hyp), atypical hyperplasia (atyp hyp), grade I adenocarcinoma (enca l), grade II adenocarcinoma (enca 2) and grade III adenocarcinoma (enca 3)

expression in epithelium of grade $\mathbb{I}$ adenocarcinoma did not differ significantly $(\mathrm{P}=$ $0.09)$ from that in atypical hyperplasia, but was significantly $(P=0.024)$ lower than in hyperplasia. Even less epithelial OR staining was observed in grade II (versus grade I, $\mathrm{P}=0.015$ ) and grade III (versus grade II, $\mathrm{P}=0.01$ ) endometrial adenocarcinoma. Less stromal OR staining was observed in grade II and III adenocarcinomas, but this was not statistically significant, partly because stroma occurred in only four out of seven poorly-differentiated adenocarcinoma specimens.

Epithelial and stromal $P R$ staining was significantly $(P=0.036$ and $P=0.0007$, respectively) lower in atypical hyperplasia than in hyperplasia. Epithelial PR staining in well-differentiated endometrial carcinoma was intermediate between that in hyperplasia and atypical hyperplasia, but not significantly different with either. High-grade adenocarcinomas showed less PR in epithelium than low-grade adenocarcinomas (for grade II versus grade I adenocarcinoma, $\mathrm{P}=0.001$; for grade III versus grade II adenocarcinoma, $\mathrm{P}=0.01$ ). The same tendency was noted for stromal PR staining but this was not statistically significant.

The histomorphology of the endometrium surrounding atypical hyperplasia was normal (proliferative or secretory, $n=2)$, atrophic $(n=3)$ or hyperplastic $(n=11)$. 

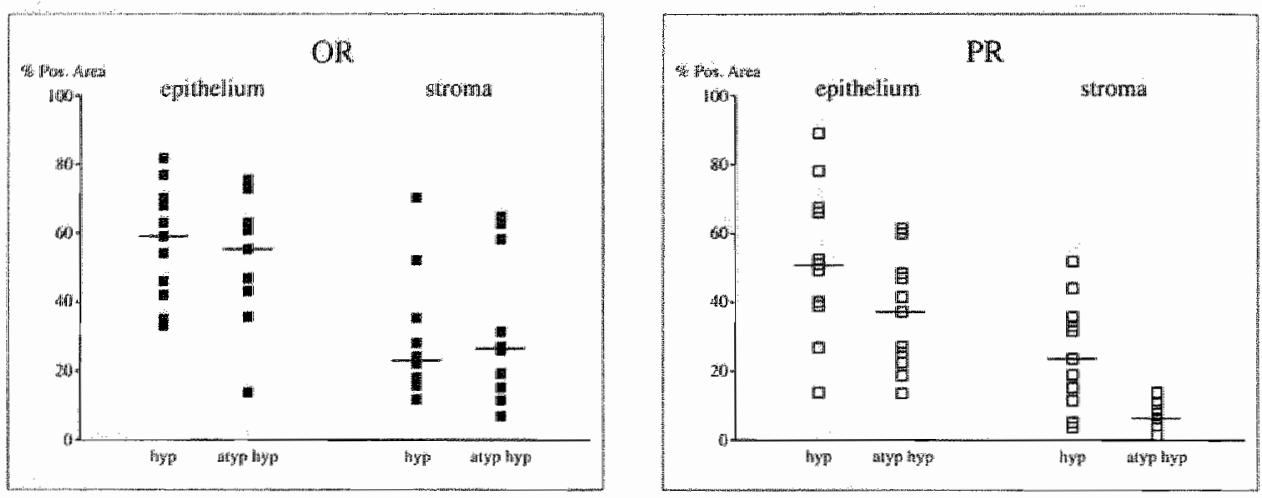

Fig. 3. Quantitative results of $O R$ and $P R$ immunocyochemistry in glandwar epitheliwm and stroma of atypical hyperplasia (atyp hyp) and surrowding hyperplasia (hyp) in II specimens (some data are superimposed; horizontal lines represent median values)

As shown in Fig. 3, stromal PR score was significantly $(\mathrm{P}=0.004)$ lower in atypical hyperplasia than in the surrounding hyperplastic mucosa. For epithelial OR and PR and stromal OR content, no significant differences were found.

\section{Discussion}

The presence of steroid receptors in target cells reflects their potential to respond to steroid hormone action (22). Endometrium is an inhomogeneous tissue and steroid receptor expression varies according to site and cell type (23). For the evaluation of receptor content in these tissues immunocytochemistry has major advantages over a radioligand binding assay because it allows assessment of the receptor content of individual cells $(24,25)$. In the present study, we have demonstrated that receptor content can be quantitated reproducibly in stromal and epithelial cells of the endometrium by computerized image analysis. Regional heterogeneity in immunocytochemical staining could be accounted for by analysing an appropiate number of fields per" section.

The main results of our studies are, firstly, that a progressive loss of steroid receptor content occurs with increasing malignant transformation; secondly, that in stromal cells in atypical hyperplasia and well-differentiated adenocarcinoma PR content decreases more than in epithelial cells; and, thirdly, that in atypical hyperplasia the . decrease in stromal PR content is in contrast with persistent OR staining.

The observation that in endometrial hyperplasia OR and PR content is high in epithelial and stromal cells is in concordance with the results of previous studies on 
normal and hyperplastic endometrium $(20,23,26,27)$. As in the normal uterus during the proliferative phases of the menstrual cycle, accumulation of tissue oestradiol has also been reported in hyperplastic endometria $(2,28)$. In normal postmenopausal endometrium, only OR expression is pronounced in epithelial and stromal cells whereas PR staining is moderate in epithelial cells and weak in stromal cells $(20,23)$. This fits with the concept that in hyperplastic endometrium the proliferative changes and the high PR level in both cell types are oestrogen-regulated via functional OR.

In atypical hyperplasia, PR staining in epithelial and stromal cells was significantly less than in hyperplasia. OR staining remained high in both tissue types, which is in slight contrast to what Thornton and Wells (23) and Bergeron et al. (26) found in a limited number of specimens. Evidence is accumulating that paracrine activities from stromal cells may regulate epithelial cell function (12-15,29-31). Decreased PR expression together with persistent $O R$ expression could therefore reflect a disturbance in hormonal interrelationships between endometrial cells in atypical hyperplasia. This conclusion is supported by our observations in atypical hyperplasia surrounded by hyperplastic endometrium. Whereas these endometria are presumably hyperoestrogenic $(1-3,32)$, in atypical hyperplasia the stromal PR content is significantly lower than in the surrounding hyperplastic endometrium. Moreover, in well-differentiated adenocarcinomas the epithelial cells displayed extensive PR expression, while $O R$ and PR staining in stromal cells was significantly decreased, which is also reported by others $(23,26,27)$. It has been recently described in human mammary (pre)neoplasia by Nenci et al. (33) and Lippman and Dickson (34) that an abnormal response of OR-containing cells to oestrogenic stimulation results in production of locally acting hormones or growth factors which may induce epithelial tumour growth. Osborne and Arteaga have described diffusible products of stromal origin which stimulate the growth of breast cancer cells (35). These observations indicate that stroma may not be an innocent bystander in the development of endometrial neoplasia, but may modulate epithelial growth by paracrine mechanisms.

The presence of functional PR has been correlated with response to progestational therapy. The extensive PR staining that we found in endometrial hyperplasia explauns why these lesions can be brought to secretory differentiation by progestational therapy in almost $100 \%$ of cases $(4,5)$. The less extensive steroid receptor immunoreactivity in endometrial atypical hyperplasia suggests that this lesion may be less sensitive to progestational therapy than hyperplasia. Indeed, cytologically atypical lesions have shown failure rates up to $75 \%$ when treated with high-dose progestogen therapy during a mean follow-up period of 5.5 years in a well-documented, prospective study (5). Progesterone therapy has been used in advanced and recurrent endometrial carcinoma and it has been shown that only $60 \%$ of cases positive for $\mathrm{PR}$ by biochemical assays will respond to treatment (11). Immunocytochemical analyses may therefore be valuable in selecting patients with endometrial carcinoma for progestogen therapy. 
In conclusion, in endometrial hyperplasia, atypical hyperplasia, and adenocarcinoma increasing epithelial atypia is correlated with a progressive loss of steroid receptor content. Stromal cells in atypical hyperplasia and well-differentiated adenocarcinoma exhibit a relative loss of PR content as compared with epithelial cells, and in atypical hyperplasia the decrease in stromal receptor content is not in parallel for $O R$ and $P R$. We suggest that defects in hormonal interactions between stromal and epithelial cells are associated with neoplastic transformation of endometrial proliferative lesions.

\section{Acknowledgements}

We thank Marij Debets-Te Baerts for expert immunocytochemistry, Mat Rousch for technical assistance, and Hans van der Putten (6) for valuable discussions. This study was partly supported by a grant from the Maurits and Anna de Kock Stichting.

\section{References}

1. Kurman RJ \& Norris H.J. Endometrial hyperplasia and metaplasia. In: Blaustein’s Pathology of the Female Genitall Tract, 3rd ed. Kurman RJ, ed. New York, Springer Verlag 1987: 322 337

2 Key TJA \& Pike MC. The dose-effect relationship between 'unopposed' oestrogens and endometrial mitotic rate; its central role in explaining and predicting endometrial cancer risk. Br J Cancer 1988, 57: 205-212

3 Gambrell RD. The role of hormones in the etiology and prevention of endometrial cancer. In: Endometrial Cancer. Clinics in Obstetrics and Gynaecology. Creasman WT, ed. London, WB Satunders Company 1986, 13:695-723

4 Kurman RJ, Kaminski PF \& Norris HJ. The behavior of endonetrial hyperplasia. A long term study of "untreated" hyperplasia in 170 patients. Cancer 1985, 56: $403-412$

5 Ferenczy $\&$ Gelfand M. The biologic significance of cytologic atypia in progestogentreated endometrial hyperplasia. Am J Obstet Gynecol 1988, 160:126- 131 .

6 Putten van der H. Endometrial hyperplasia and stage I adenocarcinoma. Thesis. Amsterdam, Schriks 1987

7 Lippman ME. Steroid homone receptors and mechanisms of growth regulation of human breast cancer. In: Diagnosis and Management of Breast Cancer. Mauke D, ed. Philadelphia, WB Saunders 1988: $326-347$

8 Creasman WT, Soper JT, McCarty KS Jr, McCarty KS Sr, Hinshaw W \& ClarkePearson DL. Influence of steroid receptor content on prognosis of early stage endometrial carcinoma. Am J Obstet Gynecol 1985, 151: $922-932$

9 Chambers JT, Macluskey N, Eisenfield A, Kohorn EI, Lawrence R \& Schwartz PE. Estrogen and progestin receptor levels as prognosticators for survival in endometrial cancer. Gyn Oncol 1988, 31: 65-77 
10 Palmer DC, Muir IM, Alexander Al, Cauch M, Bennett RC \& Quinn MA. The prognostic importance of steroid receptors in endometrial carcinoma. Obstet Gynecol 1988. 72: $388-393$

11 Ehrlich CE, Young PCM, Stehman FB, Sutton GP \& Alford WM. Steroid receptors and clinical outcome in patients with adenocarcinoma of the endometrium. Am I Obstet Gynecoll $1988,158: 796-807$

12 Cunha GR, Chung LWK, Shanmon IM, Taguchi $O \&$ Fujii $\mathrm{H}_{\text {. Hormone-induced }}$ morphogenesis and growit: role of mesenchymal-epithelial interactions. Rec Prog Horm Res $1983,39: 559-598$

13 Cooke PS, Uchima F-DA, Fujii DK, Bern HA \& Cumha GR. Restoration of nomal morphology and estrogen responsiveness in cultured vaginal and uterine epithelia transplanted with stroma. Proc Natl Acad Sci USA 1986, 83:2109-2113

14 Bigsby RM \& Cunha GR. Estrogen stimulation of deoxonibonucleic acid synthesis in uterine epithelial cells which lack estrogen receptors. Endocrinol 1986. 119:390-396

15 Roberts DK, Walker NJ \& Lavia LA. Ultrastructural evidence of stromal/ epithelial interactions in the human endometrial cycle. Am J Obstet Gynecol 1988, 158:854 - 861

16 Raymond WA \& Leong AS-Y. Oestrogen receptor staining of paraffin-embedded breast carcinomas following short fixation in formalin: a comparison with cytosolic and frozen section receptor analyses. J Pathol 1990, 160:295-303

17 Snijders M, Theunissen P, Debets-Te Baerts M \& Koudstaal Joh. Immunhistochemischer Nachweis von Östrogen- und Progesteronrezeptoren in Paraffinschnitten. Pathologe 1990, II: $236-239$

18 Bacus S, Flowers JL, Press MF, Bacus JW \& McCarty KS. The evaluation of estrogen receptor in primary breast carcinoma by computer-assisted image analysis. Am J Clin Pathol $1988,90: 233-239$

19 Shepherd JH. Revised FIGO staging for gynaecological cancer. Br J Obstet Gynaecol 1989 , 96: $889-892$

20 Snijders M, De Goeij A, Debets-Te Baerts M, Rousch M, Koudstaal J \& Bosman F. Immunocytochemical analysis of oestrogen and progesterone receptors in the normal human uterus throughout the menstrual cycle and after menopause. J Reprod Fert 1992, 94: 361 - 369

21 Altman DG \& Gardner MJ. Calculating confidence intervals for means and their differences. In: Statistics with Confidence. Gardner MJ \& Altman DG, eds. London, British Medical Joumal 1989:20 - 28

22 McCarty KS Jr, Lubahn DB \& McCarty KS Sr. Oestrogen and progesterone receptors; physiological and pathological considerations. I Clin Endocrinol Metab 1983, 12:133 - 154

23 Thornton JG \& Wels M. Oestrogen receptor in glands and stroma of normal and neoplastic human endometrium: a combined biochemical, immunohistochemical, and morphometric study. J Clin Pathol 1987, 40: 1437-1442

24 De Goeij AF, Bosman FT \& Berns EM. Determination of steroid hormone-dependency of tumours utilizing tissue sections. Survey of histochemical techniques and their application in surgical pathology. J Pathol 1986, 149: 163-172

25 Snijders MP, De Goeij AF, Koudstaal Joh et al. Is immunohistochemical analysis of oestrogen and progesterone receptors in endometrial carcinoma superior to the radioligand binding assay ? J Pathol 1990, 161:129-135

26 Bergeron C, Ferenczy A \& Shyamala G. Distribution of estrogen receptors in various cell types of normal, hyperplastic and neoplastic human endometrial tissues. Lab Invest 1988, 58: $388-345$ 
27 Bergeron $C_{\text {, }}$ Ferencey A, Toft DO \& Shyamala $G$. Immunocytochemical sidudy of progesterone receptors in hyperplastic and neoplastic endometrial tissues. Cancer Res 1988, $48: 6132-6136$

28 Vermeulen-Meiners $C$, Poortman $J$, Haspels AA \& Thijssen JH. The endogeneous concentration of estradiol and estrone in pathological human postmenopausal endometrium. I Steroid Biochem 1986, 24: 1073-1078

29 Healy DL Hodgen GD. The endocrinology of buman endometrium. Obstet Gynecol Surv $1983,38: 509-530$

30 Ylikomi T \& Tuohimaa P. Sex-steroid-sensitive stromal cells and oviduct differentiation. J Steroid Biochem 1988, 30: 473 - 476

31 McGrath Ch. Augmentation of the response of normal mammary epithelial cells to estradiol by mammary stroma. Cancer Res $1983,43: 1355-1360$

32 Fox $\mathrm{H} \&$ Buckley $\mathbf{C H}$. The endometrial hyperplasias and their relationship to endometrial neoplasia, Histopathol 1982, 6: $493-510$

33 Nenci I, Marchetti E \& Querzoli P. Commentary on human mammary preneoplasia. The estrogen receptor-promotion hypothesis. J Steroid Biochem $1988,30: 105-106$

34 Lippman ME \& Dickson RB. Mechanisms of normal and malignant breast epithelial growth regulation. I Steroid Biochem 1989, 34: 107-121

35 Osborne CK \& Arteaga CL. Autocrine and paracrine growth regulation of breast cancer: clinical implications. Breast Cancer Res Tr 1990, 15:1-13 


\section{CHAPTER 6}

\section{Preoperative oestrogen and progesterone receptor immnocytochemistry in endometrial carcinoma: correlation with clinical and histopathological parameters ${ }^{*}$}

Snijders MP, De Goeij AF, Volovics A, Koudstaal Joh, Thunnissen FB, de Haan J \& Bosman FT. Submitted for publication 


\section{Summary}

The objective of the present study was to evaluate preoperative oestrogen (OR) and progesterone receptor (PR) immunocytochemistry in relation with clinical and histopathological prognostic factors in endometrial carcinoma. To this end, the cellular OR and PR content was analysed by computerized image analysis in paraffin sections of diagnostic curettage and/or biopsy specimens from 169 endometrial carcinoma patients. Receptor scoring was correlated with clinical and histopathological parameters after pathological staging, and with radiochemical steroid receptor analysis of 49 curettings. Only for $\mathrm{PR}$, a weak linear relationship ( $\mathrm{r}$ $=0.45$ ) was found between the results of radiochemistry and immunocytochemistry of the tumour epithelium. Significant inverse correllations were found between immunocytochemical OR or PR scores and FIGO stage (for OR: $\mathrm{P}=0.002$; for PR: $P=0.002$ ), pathological stage (for $O R: P=0.003$; for $P R: P=0.002$ ), depth of myometrial invasion (for $P R: P=0.001$ ), histological grade (for $O R$ : $P=0.005$; for PR: $\mathrm{P}=0.003$ ) and tumourtype (for $\mathrm{OR}: \mathrm{P}=0.026$; for $\mathrm{PR}: \mathrm{P}=0.001$ ). FIGO stage I carcinomas revealing extracorporal tumour growth (i.e. pathological stage II, III or IV) were significantly more often associated with absent or very low $O R(P=0.02)$ or PR ( $P=0.02)$ immunoreactivity in the curettings than tumours with concordant FIGO- and pathological stage I. In conclusion, absent or very low OR or PR expression appears strongly associated with adverse clinical and histopathological parameters. Steroid receptor immunocytochemistry is valuable as preoperative procedure for guidance of surgical-pathological staging in endometrial carcinoma patients.

\section{Introduction}

Approximately $75 \%$ of patients with endometrial cancer present with early stage disease (1). Until recently, patients were classified into high or low risk groups using clinical FIGO staging based on fractional curettage (2). However, about $25 \%$ of patients in the low risk group with clinically stage I disease will die of recurrent cancer (1), presumably due to early metastatic spread (3). Hence, the development of specific criteria relevant to tumour behaviour at diagnosis is urgently needed.

Recently, FIGO staging has been changed from a preoperative clinical to an intraand postoperative surgical-pathological assessment (4). Peritoneal cytology, lymph node status, depth of myometrial invasion, and histological differentiation have been introduced as staging criteria. However, several problems are associated with the use of these criteria. Extensive surgery including routine lymphadenectomy leads to increased morbidity and mortality in endometrial cancer patients, who are frequently elderly or obese and may have multiple underlying medical problems $(5,6)$. Some 
authors recommend lymphadenectomy only if the tumour is found to be poorlydifferentiated on histologic examination of the curettings and/or if there is deep myometrial invasion at hysterectomy $(7,8)$. But, histological grading on curettage specimens may differ in up to $54 \%$ from the findings in the operative specimen $(9,10)$. Furthermore, the degree of differentiation is subjectively assessed with rather high inter- and intraobserver variability (11). Intraoperative evaluation of depth of myometrial invasion by macroscopic inspection may not be appropiate (12).

With respect to clinical management, further analysis of the curettage material may yield important information on tumour aggressiveness preoperatively. Several studies have established the clinical value of oestrogen receptor (OR) and progesterone receptor (PR) determination in endometrial cancer (13-17). However, the radiochemically assayed receptor status of the tumour does not always accurately predict prognosis and response to hormonal therapy (18-20). Immunocytochemical steroid receptor analysis is more specific as it allows assessment of receptor expression in tumour cells in a heterogeneous tissue such as uterus $(21,22)$.

It is the purpose of the present study to evaluate steroid receptor content in relation with the clinical and histopathological prognostic factors of endometrial carcinoma. To this end, quantitative analysis of $\mathrm{OR}$ and PR immunocytochemistry in diagnostic specimens was compared to the postoperative pathological findings in 169 patients. In 49 curettage samples, immunocytochemical OR and PR scores were compared with the steroid receptor levels obtained by radiochemical cytosol technique. Paraffin sections were used for receptor immunocytochemistry to ensure optimal preservation of histomorphology (23), and computerized image analysis was used to quantitate steroid receptor immunocytochemistry objectively $(24,25)$.

\section{Materials and methods}

\section{Clinical data}

All 185 patients, consecutively treated for uterine corpus cancer (at the De Wever Hospital Heerlen) from January 1977 to December 1987, were studied retrospectively. After exclusion of 11 non-malignant specimens (atypical hyperplasia) and 5 sarcomas, a series of 169 patients with a histopathologically confirmed diagnosis of endometrial carcinoma was included for further analysis. Age ranged from 19 to 85 years (median 61 years). Clinical staging based on fractional curettage was determined according to FIGO guidelines (2). No preoperative radiotherapy was administered; between diagnostic curettage and surgery all patients were given $200 \mathrm{mg}$ gestonoron capronate injections (Depostat ${ }^{\mathrm{R}}$, Schering, The Netherlands) twice weekly. Within two weeks after initial diagnosis the pathological stage was assessed by using intraoperative observations and histopathological examination of the extirpated 
Table 1. Staging of 169 endometrial carcinoma patients: preoperative clinical (FIGO) wersws postoperative pathological stage

\begin{tabular}{llcc}
\hline stage & \multicolumn{1}{c}{ classffication } & $\begin{array}{c}\text { FlGO } \\
\text { stage } \\
n\end{array}$ & $\begin{array}{c}\text { pah. } \\
\text { stage } \\
n\end{array}$ \\
\hline I & confined to uterine body & 157 & 137 \\
II & extension to cervix & 3 & 8 \\
III & $\begin{array}{l}\text { extratuterine pelvic extension } \\
\text { IV extenstion outside pelvis } \\
\text { and/or perforation } \\
\text { bladder or tectum }\end{array}$ & 3 & 16 \\
& & 6 & 8 \\
\end{tabular}

specimen (see Table 1). During the study period peritoneal cytology was not routinely obtained; only in patients with enlarged pelvic or paraaortic lymph nodes biopsies were taken. Myometrial invasion was classified as less $(<1 / 2)$ or more $(\geq$ 1/2) than half of the myometrium. Two patients were not operated because of severe clinical problems. For statistical analyses, the FIGO- or pathological stages II, III and IV were grouped.

\section{Histological data}

Microscopic slides from all curettage, biopsy and hysterectomy specimens were reevaluated by two pathologists reaching consensus for histological tumour type and grade, without knowledge of the clinical or steroid receptor status. Tumour type classification was performed according to the criteria of the International Society of Gynecological Pathologists (26), histological grading according to the revised FIGO definitions (4). For statistical analyses, the tumour types were divided into three groups: typical adenocarcinoma $(n=141)$, adenoacanthoma $(n=20)$, and uncommon type of carcinoma $(n=8$ : adenosquamous, $n=1$; serous papillary, $n=1$; clear cell, $n$ $=3$; squamous $\{27\}, \mathrm{n}=2$; undifferentiated, $\mathrm{n}=1$ ). The histological grades were grouped in well-differentiated (grade $\mathrm{I}, \mathrm{n}=111$ ), and moderately- or poorlydifferentiated ( $n=58$ : grade II., $n=42$; grade III, $n=16$ ).

\section{Steroid receptor immunocytochemistry}

Paraffin blocks from the diagnostic curettings and/or biopsies processed for routine histopathological examination were retrieved at the Department of Pathology, 
De Wever Hospital Heerlen. Steroid receptor immunocytochemistry was performed on $5 \mu \mathrm{m}$ sections as described earlier $(23,28)$. Briefly, before OR staining the sections were enzymatically digested with $0.1 \%$ bovine pancreatic trypsin in $0.1 \%$ $\mathrm{CaCl}_{2}$-solution $\left(\mathrm{pH} 7.8\right.$ ) at $37^{\circ} \mathrm{C}$ for $30 \mathrm{~min}$. After incubation with the primary rat anti-OR monoclonal antibody (H222 SP $\gamma$, ER-ICA kit, gift from Abbott Laboratories, The Netherlands; undiluted; overnight, at room temperature $=\mathrm{RT}$ ), the sections were incubated with biotinylated sheep anti-rat immunoglobulin (Amersham, UK; 1: 200; $2 \mathrm{~h}, \mathrm{RT})$ followed by avidin-biotin peroxidase complex (ABC, Vector Laboratories, USA; $1: 200 ; 2$ h, RT).

For PR, the sections were incubated with mouse anti-PR antibody (mPR I, ITK Diagnostics, The Netherlands; 1 : 800 ; overnight at $4^{\circ} \mathrm{C}$ ), followed by biotinylated sheep anti-mouse immunoglobulin (Amersham; $1: 200 ; 90 \mathrm{~min}$, RT) and peroxidaselabelled streptavidin (TTK Diagnostics; $\mathbb{1}: 1000 ; 90 \mathrm{~min}, \mathrm{RT}$ ).

Finally, the sections were incubated for $7 \mathrm{~min}$ in a substrate solution containing diaminobenzidine (DAB) with $0.002 \%$ hydrogen peroxide and $1 \mathrm{mM}$ imidazol. The sections were counterstained with methyl green and mounted in Entellan (Merck, Germany). As a negative control, adjacent sections were stained according to the same procedures but with normal rat IgG instead of rat anti-OR antibody and mouse IgG instead of mouse anti-PR antibody. Sections of OR and PR positive human mammary carcinomas and/or rabbit uterus served as positive controls in every staining procedure.

\section{Computerized image analysis of steroid receptor staining}

Quantification of receptor staining was performed in the diagnostic curettage or biopsy specimens with the Cell Analysis System 200 (CAS 200, Becton Dickinson, Belgium) which has two sensors in parallel, digitizing the images at different wavelenghts (24). The nuclei were identified by virtue of the green counterstain with the use of a $650-\mathrm{nm}$ filter. The DAB reaction product was measured using a 500-nm filter Nuclear staining threshold was set interactively under visual inspection. The antibody threshold discriminating between positive and negative cells was adjusted as described by Bacus et al. (24). The percentage positive area (\% Pos. Area) was defined as the number of pixels within nuclei having a chromogen intensity at 500 nm above the control antibody threshold, divided by the total number of nuclear pixels, times 100. Without prior knowledge of histological tumourtype and grade assignment or clinical course, OR and PR immunoreactivity was analysed by one observer (M.P.S.). In each specimen, at least 15 high power ( $x$ 400) fields of tumour epithelium and 10 fields of stroma (present in 166 specimens) per section were analysed (28). If in an area elements other than endometrial tumour epithelium or stroma were present, these were excluded from the measurement. The immunocytochemical receptor score (in \% Pos. Area) refers to the malignant epithelial component, unless indicated otherwise. 


\section{Radiochemical assay on cytosol preparations}

From 1983 on, radiochemical analysis of steroid receptors was routinely performed on uterine curettings under the suspicion of harbouring an endometrial malignancy, if enough fresh tissue could be obtained: thus, the cytosol OR and PR content was determined for 49 patients. Cytosol OR and PR were measured with a multiple point dextran-coated charcoal assay according to the guidelines of the EORTC (29) with ${ }^{1251-o e s t r a d i o l ~ a n d ~ 17 \alpha-m e t h y l-3 H-P r o m e g e s t o n e ~(R 5020) . ~ T h e s e ~ a s s a y s ~ w e r e ~}$ performed in the Isotope-laboratory of the De Wever Hospital Heerlen (head Dr A. Gijzen), which participates in a steroid receptor assay quality control program executed in Europe under auspices of EORTC (30).

\section{Statistical analysis}

For direct quantitative comparisons of immunocytochemical and (logarithmically transformed) radiochemical steroid receptor values scatterplots were made and correlation coefficients calculated. Before analysing \% Pos. Area (continuous variable) of $\mathrm{OR}$ and $\mathrm{PR}$ immunoreactivity in relation with clinical and histopathological criteria, the range of $\mathrm{OR}$ and $\mathrm{PR}$ values was arbitrarily divided into four groups having (approximately) equal numbers of patients. The categories defined by these quartiles were as follows: for OR absent or very low $(<16 \%, \mathrm{n}=$ $40)$, low $(16-32 \%, \mathrm{n}=42)$, moderate $(33-47 \%, \mathrm{n}=43)$ ) or strong $(>47 \%, \mathrm{n}=44)$ immunoreactivity. For PR absent or very low $(<6 \%, n=40)$, low $(6-19 \%, n=44)$, moderate $(20-33 \%, \mathrm{n}=42)$ or strong $(>33 \%, \mathrm{n}=43)$ immunoreactivity. Clinical and histopathological variables were analysed for association with immunocytochemical OR and PR scoring categories by Chi-Square tests of linear trend (31), or by ordinary Chi-Square tests (with BMDP 4F statistical package, 1990 version).

\section{Results}

\section{Immunocytochemical receptor analysis}

Both OR and PR were localized in the cell nuclei. Receptor immunoreactivity could be identified in all tissue components but with variable staining patterns. Within individual specimens, the malignant epithelium frequently demonstrated heterogeneity of staining while the surrounding stroma stained more uniform.

In Figs $I a$ and $b$, scatter diagrams are presented for the comparison of OR and PR scores between malignant epithelium and stroma. Regression analysis reveals very weak linear relationships between the $\%$ Pos. Area in tumour epithelium and stroma (for OR: $\mathrm{r}=0.39,95 \% \mathrm{c} . \mathrm{i}_{\mathrm{.}}=0.25-0.51$; for PR: $\mathrm{r}=0.43,95 \% \mathrm{c} . \mathrm{i}_{\mathrm{s}}=0.29-0.55$ ). 

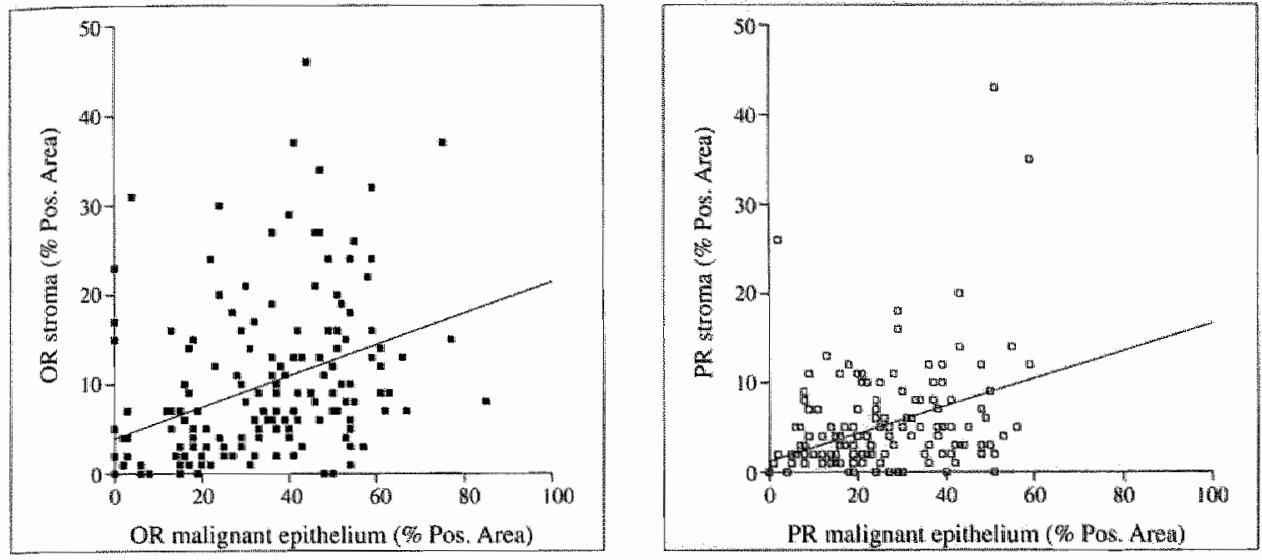

Fig. Ja and $1 b$. Comparison of inmunocytochemical $O R(\mathbf{D})$ and $P R(\square)$ scores from malignant epithelium and stroma in 166 endometrial carcinoma samples. The regression lines are characterized as follows: for $O R: y=3.9( \pm 1.2)+0.18( \pm 0.03) x ;$ for PR: $y=1.2( \pm 0.7)+0.15( \pm 0.03) x$.

\section{Comparison of radiochemical with immunocytochemical quantitation of steroid receptors}

The levels of $\mathrm{OR}$ and $\mathrm{PR}$ were compared as determined by radiochemical cytosol assay (in femtomoles/mg protein; logarithmically transformed) and immunocytochemistry of tumour epithelium (in \% Pos. Area). As illustrated in Figs $2 a$ and b, a very weak linear relationship was found for $P R$ only (for OR: $r=0.19,95 \%$ c.i. $=$ - $0.11-0.46$; for PR: $r=0.45,95 \%$ c.i. $=0.18-0.65$ ). Radiochemical assay yielded a higher number of receptor positive lesions than immunocytochemical assay.
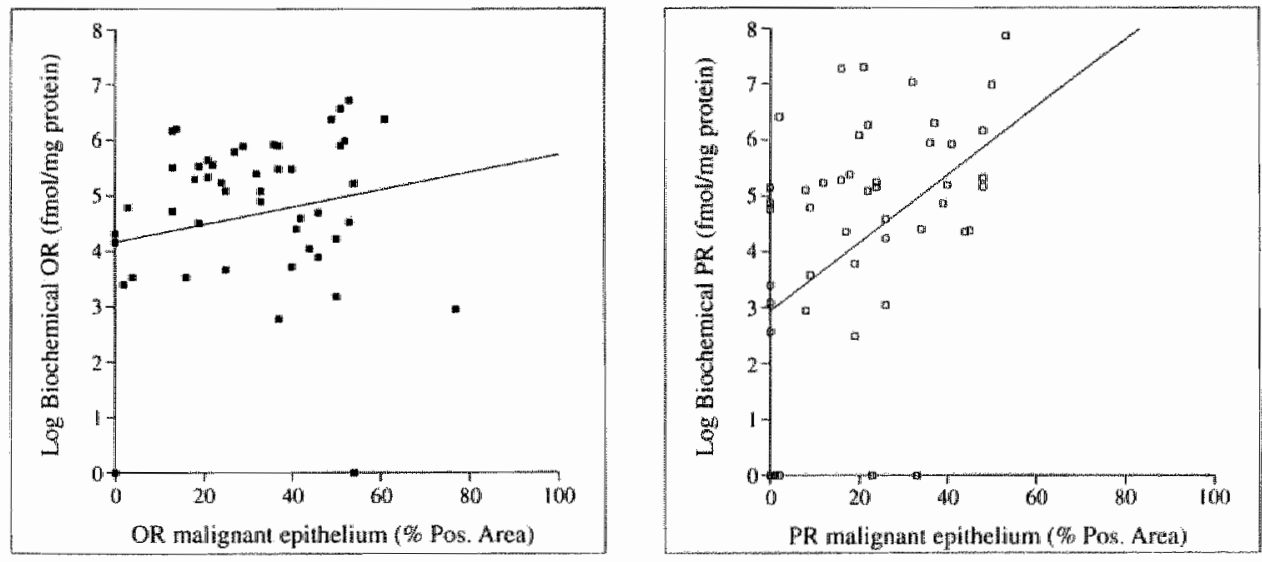

Fig. $2 a$ and $2 b$. Comparisan of $O R(\square)$ and $P R(\square)$ values derived from radiochemical cyosol assay (in fmol'mg protein) and immunocytochemistry of tumour epithelium (in \% Pos. Area) in 49 curettage specimens with endometrial cancer. The regression lines are characterized as follows: for OR: $y=4.2( \pm 0.43)+0.02( \pm 0.01) x ;$ for PR: $y=2.9( \pm 0.47)+0.06( \pm 0.02) x$ 
Table $2 a$. Assactanions of epithelial OR score with chical and histopathological criteria in 169 patients with endometrial carcinomd

\begin{tabular}{|c|c|c|c|c|c|c|}
\hline & \multicolumn{5}{|c|}{ OR inmunoreactivity } & \multirow[b]{2}{*}{$p *$} \\
\hline & $n$ & $\begin{array}{c}\text { absent or } \\
\text { very low } \\
\text { n }(\%)\end{array}$ & $\begin{array}{l}\text { low } \\
n(\%)\end{array}$ & $\begin{array}{l}\text { moderate } \\
n(\%)\end{array}$ & $\begin{array}{l}\text { strong } \\
n(\%)\end{array}$ & \\
\hline \multicolumn{7}{|l|}{ Fico stage } \\
\hline 1 & 157 & $32(21)$ & $40(26)$ & $42(27)$ & $43(28)$ & \\
\hline III. III, IV & 12 & $8(75)$ & $2(17)$ & $1(8)$ & $18)$ & 0.002 \\
\hline \multicolumn{7}{|c|}{ pathological stage } \\
\hline 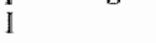 & 137 & $24(18)$ & $37(27)$ & $37(27)$ & $39(28)$ & \\
\hline 11,111, IV & 32 & $16(50)$ & $5(16)$ & $6(19)$ & $5(16)$ & 0.003 \\
\hline \multicolumn{7}{|c|}{ myometrial invasion \# } \\
\hline$<1 / 2$ & 90 & $18(20)$ & $24(27)$ & $25(28)$ & $23(26)$ & \\
\hline$\geq 1 / 2$ & 77 & $21(27)$ & $17(22)$ & $18(23)$ & $21(27)$ & 0.6 \\
\hline \multicolumn{7}{|c|}{ histological grade } \\
\hline 1 & 111 & $18(16)$ & $29(26)$ & $31(28)$ & $33(30)$ & \\
\hline II or III & 58 & $22(38)$ & $13(22)$ & $12(21)$ & $11(19)$ & 0.005 \\
\hline \multicolumn{7}{|c|}{ tumour type } \\
\hline adeno & 141 & $30(21)$ & $38(27)$ & $34(24)$ & $39(28)$ & \\
\hline acanthoma & 20 & $4(20)$ & $3(15)$ & $8(40)$ & $5(25)$ & \\
\hline uncommon & 8 & $6(75)$ & $1(13)$ & $\mathbb{N}(13)$ & - & $0.026^{+}$ \\
\hline totall & 169 & $40(24)$ & $42(25)$ & $43(25)$ & $44(26)$ & \\
\hline \multicolumn{7}{|c|}{$\begin{array}{l}\text { At wo patients were treated without surgery } \\
+ \text { Chi-Square rest }\end{array}$} \\
\hline
\end{tabular}

\section{Association of steroid receptor immunocytochemistry with clinical and histopathological criteria}

In Tables $2 a$ and $b$, all 169 patients are classified according to their quartile distribution for \% Pos. Area OR and PR of tumour epithelium, and to their categories for various clinical and histopathological criteria.

Mean age of the patients was 6l years (range 19 to 85 years). No significant correlations between OR or PR scores and age were observed (data not shown).

Preoperative clinical FIGO staging revealed stage I cancer in $93 \%(157 / 169)$ of the patients. In the grouped FIGO stages II, III and IV, OR and PR scores were found to be significantly lower.

Postoperative pathological staging revealed that $81 \%(137 / 169)$ of the tumours were restricted to the uterine corpus (stage I). Both OR and PR levels were significantly lower in the grouped pathological stages II, III and IV. 
Table 2 b. Associarons of epithelial PR score wit clinical and histopahological criteria in 169 patients with endometrial carcinoma

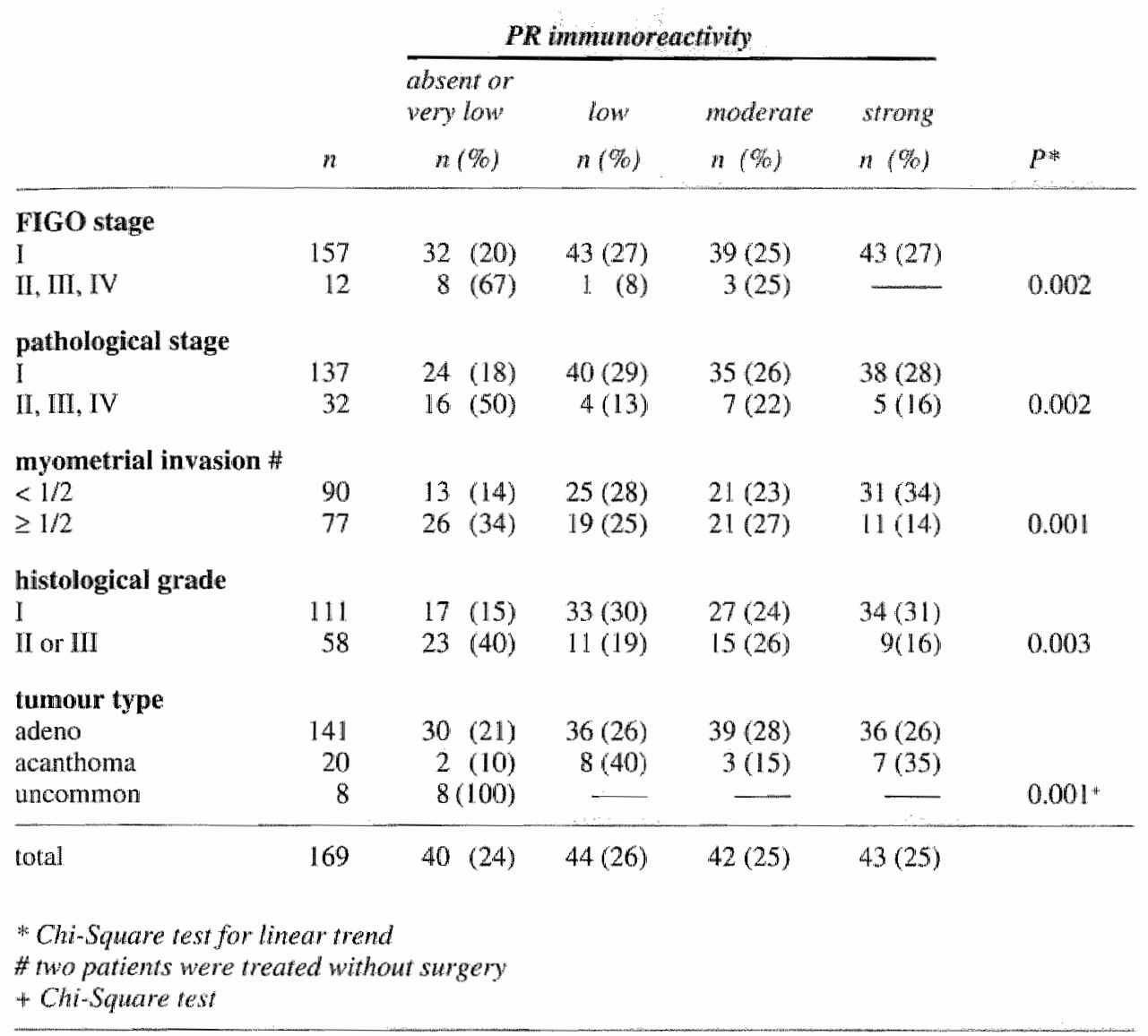

Depth of myometrial invasion was assessed on the resected specimen and patients were found to be approximately equally distributed between superficial $(<1 / 2, n=$ 90) and deep $(\geq \mathbb{R} / 2, n=77)$ inwasion. In contrast to $O R$, immunocytochemical PR scores were significantly lower in deeply invading tumours than in superficially growing neoplasms.

Histological grading revealed $70 \%$ (111/158) well-differentiated (grade I) tumours. Moderately (grade $I, n=42$ ) and poorly (grade $I I, n=16$ ) differentiated neoplasms showed significantly lower OR and PR scores.

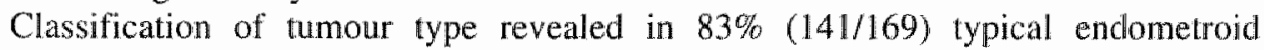
adenocarcinoma and in 12\% (20/169) adenoacanthoma. Both types showed higher levels of $O R$ and $P R$ expression than the uncommon histological subtypes 
Table 3. Distribution of lowest category OR and PR expression in 157 clinical (FIGO) stagel endometrial cancer specimens

\begin{tabular}{cc}
\multicolumn{2}{c}{ pathological stage } \\
$I \quad$ III or $I V$ \\
$(n=137)$ & $(n=20)$
\end{tabular}

OR absent or very low

$24(18 \%)$

$8(40 \%)$

0.02

PR absent or very low

$24(18 \%)$

$8(40 \%)$

0.02

* Chi-Square test

\section{OR and PR immunocytochemistry in FIGO- versus pathological stage I tumours}

Postoperative pathological stage differed from preoperative FIGO stage I disease in 20 patients $(20 / 157=13 \%)$ : the resected specimen showed tumour extension to the cervix (stage II) in five cases, extra-uterine pelvic extension (stage III) in 13 cases and extension outside the pelvis (stage IV) in two cases. Table 3 shows the distribution of 32 patients with the lowest category immunoreactivity for $\mathrm{OR}(<16 \%)$ and $\mathrm{PR}(<$ $6 \%$ ) in the curettings of 157 FIGO stage I cancers: carcinomas revealing postoperatively a pathological stage II, III or IV showed significantly more often (40\%) lowest category OR and PR immunoreactivity than tumours with concordant FIGO and pathological stage I ( $18 \%)$.

\section{Discussion}

With respect to $O R$ and $P R$ immunoreactivity, only very weak linear relationships were found between the malignant epithelium and the intervening stroma in endometrial carcinomas. The ratio of stromal to epithelial receptor expression appears much lower for PR than for OR. Thus, the reported (28) relative loss of stromal PR content with increasing malignant transformation now appears a consistent finding in a large series of endometrial carcinomas.

A weak linear relationship between radiochemical and immunocytochemical receptor assay was found for PR only when using computerized image analysis of receptor immunostaining. In accordance with others $(21,22,32)$, we found higher levels of $\mathrm{OR}$ and $\mathrm{PR}$ in radiochemical assays when compared with immunocytochemical receptor analysis of tumour epithelium. This is presumably due to the 
presence of receptor in non-malignant tissue elements 'contaninating' the cytosols for radiochemicall assay $(21,22,33)$. It is concluded that radiochemical assays of cytosol may not accurately reflect the receptor content of the endometrial cancer component. Immunocytochemical analysis appears more appropiate to predict tumour behaviour, as it allows the specific assessment of tumour cell receptor content (34).

Several clinical and histopathological factors have been demonstrated to be valuable for the management of patients with endometrial carcinoma. In this study, the clinical factors age, preoperative FIGO stage, postoperative pathological stage, and depth of myometrial invasion, as well as the histopathological factors tumour grade, and type were analysed for a possible correlation with OR and PR expression.

Associated with age, endometrial cancer may occur in two different forms: i.e. an oestrogen-related form in younger women and a second, more aggressive form, unrelated to oestrogenic stimulation in older women (26). Increasing age at diagnosis may be parallelled by a decreasing steroid receptor level as was reported for PR by Carcangiu et al. using immunocytochemistry (35). In our study, however, no significant relationships between age and OR or PR expression were observed.

The stage of the tumour is one of the most important prognostic factors. OR and PR values showed significant inverse correlations both with FIGO and pathological stage. Metastatic tumour growth appears to be associated with a lack of steroid receptor content. The extent of myometrial invasion was significantly correlated with absent or minor PR immunoreactivity in the curettage specimen, indicating a more agressive potential of these tumours. As deep myometrial invasion of tumour growth may be accompanied with up to $23 \%$ paraaortic lymph node metastasis in clinical stage I disease $(3,7)$, preoperative knowledge of absent or low PR status may guide careful surgical staging procedures.

Histological grading of endometrial carcinomas has been more clearly defined and introduced as prognostic factor in the revised FIGO staging criteria (4). In concordance with other immunocytochemical studies $(21,28,35)$, we found a progressive loss of OR and PR immunoreactivity with increasing malignant epithelial transformation. This suggests that endocrine regulatory mechanisms are better preserved in more differentiated tumours. Although the response to progestational treatment correlates with histological differentiation of the tumour (36), the results within the various subgroups are quite variable: approximately $50 \%$ of recurrent grade I and $10 \%$ of grade III tumours will respond (36). Steroid receptor data correlate far better with responsiveness to progestational therapy $(13,36)$ and thus may provide the maximal discriminant for selection of the therapeutic procedure in recurrent endometrial cancer. Histological type of the tumour correlates with OR and PR scores: in adenocarcinomas and adenoacanthomas a higher receptor score is found than in uncommon tumourtypes. This is in accordance with the findings of Carcangiu et al. (35).

Identification of patients with early disease who are at risk of extracorporal tumour extension is a major problem in the management of patients with endometrial cancer. 
Our data show that patients with a clinical FIGO stage I disease and absent or very low $\mathrm{OR}$ or $\mathrm{PR}$ immunoreactivity in the curettage specimen have a significantly higher chance that metastases are found. Hence, a finding of absent or minimal steroid receptor expression in a diagnostic specimen revealing endometrial carcinoma should initiate careful surgical-pathological staging.

In conclusion, absent or very low $\mathrm{OR}$ and $\mathrm{PR}$ immunoreactivity in the diagnostic specimen appears strongly associated with unfavourable clinical and histopathological factors in endometrial carcinoma. Apart from the assessment of histological grade and tumour type, steroid receptor immunocytochemistry is valuable as a preoperative procedure for guidance of surgical-pathological staging. The potential prognostic relevance of receptor immunocytochemistry has to be evaluated in association with long term follow-up findings.

\section{Acknowledgements}

We are indebted to Marij Debets-Te Baerts for expert immunocytochemistry, to Dr P Theunissen for histopathological reevaluation, and to Marion de Leeuw and Ineke van Lijnschoten for valuable help with statistical analyses of the results. This study was partly supported by a grant from the Maurits and Anna de Kock Stichting.

\section{References}

1 FIGO. Annual report on the results of treatment in gynecological cancer. Vol 21. Petterson F, ed. Stockholm, Radiumhemmet 1991

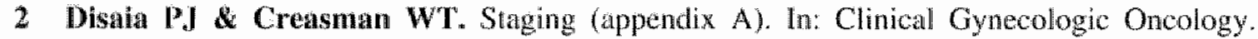
Bircher S\& Gunter A, eds. St. Louis,C.V. Mosby 1989:647-649

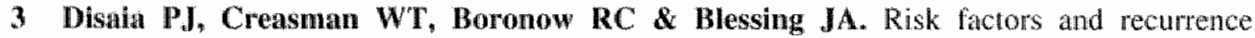
pattems in stage I endometrial carcinoma. Am J Obstet Gynecol 1984, 151: 1009- 1015

4 Shepherd JH. Revised FIGO staging for gynaecological cancer Br J Obstet Gynaecol 1989. 96: $889-892$

5 Lewandowski G, Torrisi J, Potkul RK et all. Hysterectomy with extended surgical staging and radiotherapy versus hysterectomy alone and radiotherspy in stage I endometrial cancer: a comparison of complication rates. Gyn Oncol 1990, 36: 401-404

6 Clarke-Pearson D, Cliby W, Soper J et al. Morbidity and mortality of selective lymphadenectomy in early-stage endometrial cancer. Gyn Oncol 1991,40:168

7 Creasman WT, Morrow CP, Bundy BN, Homesley HD, Graham JE\& Heller PB. Surgical pathologic spread patterns of endometrial cancer. Cancer 1987, 60: 2035 - 2041

8 Morrow CP, Bundy BN, Kurman RJ et al. Relationship between surgical-pathological risk factors and outcome in clinical stage I and II carcinoma of the endometrium: at Gynecologic Oncology Group study. Gyn Oncol 1991, 40: $55-65$ 
9 Soothill PW, Alcock CJ \& Mackenie IZ Discrepancy between curettage and hysterectomy histology in patients with stage I uterine malignancy. Br J Obstet Gynaecol $1989,96: 478-481$

10 Winkler $B$, Alvarez $S$, Richart RM \& Crum CP. Pitfalls in the diagnosis of endometrial neoplasia. Obstet Gynecol 1984,64: 185- 194

11 Putten van der H. Endometrial hyperplasia and stage Il adenocarcinoma. Thesis. Amsterdam, Schriks 1987

12 Goff BA \& Rice LW. Assessment of depth of myometrial invasion in endometrial adenocarcinoma. Gyn Oncol 1990, 38: $46-48$

13 Ehrlich CE, Young PC, Stehman FB, Sutton GP \& Alford WM. Steroid receptors and clinical outcome in patients with adenocarcinoma of the endometrium. Am J Obstet Gynecol $1988,158: 796-807$

14 Chambers JT, Macluskey N, Eisenfield A, Kohorn EI, Lawrence R \& Schwarta PE. Estrogen and progestin receptors as prognosticators for survival in endometrial cancer. Gyn Oncol 1988, 31:65-77

15 Palmer DC, Mür IM, Alexander AI, Cauchi M, Bennett RC Q Quinn MA. The prosnostic importance of steroid receptors in endometrial carcinoma. Obstet Gynecol 1988 . $72: 388-393$

16 Sockwell Ingram $S_{3}$ Rosenman J, Heath R, Morgan TM, Moore D \& Varia M. The predictive value of progesterone receptor levels in endometrial cancer. Int J Radiation Oncology Biol Phys 1989, 17:21 - 27

17 Kleine W, Maier T, Geyer H \& Pfleiderer A. Estrogen and progesterone receptors in endometrial cancer and their prognostic relevance. Gyn Oncol 1990, 38: 59 - 65

18 Lindahl B, Alm P, Fernö M, Grundsell H, Norgren A \& Tropé C. Relapse of endometrial carcinoma related to steroid receptor concentration, staging, histological grading, and myometrial invasion. Anticancer Res 1986, 6: $1317-1320$

19 Utaaker E, Iversen $\mathrm{OE} \&$ Skaarland E. The distribution and prognostic implications of steroid receptors in endometrial carcinomas. Gyn Oncol 1987, 28; 89 - 100

20 Quinn MA, Cauchi M, Fortune D. Endometrial carcinoma: steroid receptors and response to medroxyprogesterone acetate. Gytnecol Oncol 1985, 21:314 - 319

21 Soper JT, Segreti EM, Novotny DB, Mutch D, Creasman WT \& MeCarty KS Jr. Estrogen and progesterone receptor content of endometrial carcinomas: comparison of total tissue versus cancer component analysis. Gyn Onco! 1990, 36: 363-368

22 Snijders MP, De Goeij AF, Koudstaal Joh et al. Is immunohistochemical anthasis of oestrogen and progesterone receptors in endometrial carcinoma superior to the radioligand binding assay ? I Patholl 1990, 161:129-135

23 Snijders M, Theunissen P, Debets-Te Baerts M \& Koudstaal Joh. Immunhistochemischer Nachweis von Östrogen- und Progesterontezeptoren in Paraffinschnitten. Pathologe 1990, 1 J: $236-239$

24 Bacus S, Flowers JL, Press MF, Bacus JW \& McCarty KS. The evaluation of estrogen receptor in primary breast carcinoma by computer-assisted image analysis. Am II Clin Pathol $1988.90: 233-239$

25 McClelland RA, Wilson D, Leake R, Finlay P Nicholson I. A multicentre study into the reliability of steroid receptor immunocytochemical assay quantification. Eur J Cancer 1991 , $27 \div 711-715$ 
26 Kurman RJ \& Norris HI. Endometrial carcinoma. In: Blaustein"s Pathology of the Female Genital Tract, 3rd ed. Kurman RJ, ed. New York, Springer-Verlag 1987: 338-372

27 Sluymer $\mathbf{A}$, Ubachs JMH, Stoot JE, Steyer $\mathbf{M} \&$ Koudstaal Joh. Clinical and pathological aspects of benign and malignant squamous epithelium of the corpus uteri; a report of two cases. Eur J Obstet Gynecol Bilol Peprod 1991, 39: 71 - 75

28 Snijders M, De Goeji AF, Thunnissen E, Koudstaal Joh, de Haan J \& Bosman FT. Oestrogen and progesterone receptor immunocytochemistry in human hyperplastic and neoplastic endometrium. J Pathol 1992, 166:171-177

29 EORTC Breast Cancer Cooperative Group. Revision of the standards for assessment of hormone receptors in human breast cancer. Eur J Cancer Clin Oncol 1980, 16: 1513-1515

30 Koenders A \& Thorpe SM. Standardization of steroid receptor assays in human breast cancer. Long-term within laboratory and between laboratory variation of estrogen and progesterone receptor assays. Eur J Cancer Clin Oncol 1986, 22:945-952

31 Cochran WG. Some methods of strengthening the common ChiSquare tests. Biometrics $1954,10: 417 \cdot 441$

32 Chambers JT, Carcangiu ML, Voynick IM \& Schwartz PE. Immunohistochemical evaluation of estrogen and progesterone receptor content in 183 patients with endometrial carcinoma. Part II: correlation between biochemical and immunohistochenaical methods and survival. Am J Clin Pathol 1990, 94: 255 - 260

33 Parl FF \& Posey YF. Discrepancies of the biochemical and immunohistochemical estrogen receptor assays in breast cancer. Hum Pathol 1988, 19:960-966

34 De Goeij AF, Bosman FT \& Berns EM. Determination of steroid hormone-dependency of tumours utillizing tissue sections. Survey of histochemical techniques and their application in surgical pathology. J Pathol 1986, 149: 1.63-172

35 Carcangiu ML, Chambers JT, Voynick IM, Pirro M \& Schwartz PE. lmmuno histological evaluation of estrogen and progesterone receptor content in 183 patients with endonetrial carcinoma. Part I: clinical and histologic correlates. Am I Clin Pathol 1990, 94: $247-254$

36 Kneale BL. Adjunctive and therapeutic progestins in endometrial cancer. In: Endometrial Cancer. Clinics in Obstetrics and Gynaecology. Creasman WT, ed. London, W.B.Saunders Company $\llbracket 986,13: 789-81 \rrbracket$ 


\section{CHAPTER 7}

\section{Prognostic relevance of oestrogen and progesterone receptor immunocytochemistry in endometrial carcinoma*}

Snijders MP, De Goeij AF, Volovics A, Koudstaal Joh, Thunnissen FB, de Haan J \& Bosman IFT. Submitted for publication 


\section{Summary}

The objective of this study was to relate oestrogen (OR) and progesterone receptor (PR) immunocytochemistry with long term follow-up in patients with endometrial carcinoma. To this end, the quantitative immunocytochemical assay of OR and PR in the diagnostic curettage or biopsy specimens was correlated with long term survival in 169 endometrial cancer patients. Univariate analysis revealed that, apart from FIGO stage ( $\mathrm{P}<0.0001)$, pathological stage $(\mathrm{P}<0.0001)$, depth of myometrial invasion $(P=0.0006)$, and histological grade $(P=0.01)$, scoring of $O R(P<0.0001)$ as well as $\mathrm{PR}(\mathrm{P}<0.000 \mathrm{l})$ immunoreactivity significantly predicted long term survival. Multivariate analysis, using the Cox regression model, revealed that $O R$ as well as PR scoring added significant prognostic information regarding long term survival for patients in all stages of endometrial cancer. Analysis of prognostic factors in 15 pathological stage I endometrial cancer patients with recurrent disease showed that absent or very low OR or PR immunoreactivity in the diagnostic specimen was an important predictor of treatment failure. Given the statistical limitations of this retrospective study in 169 patients, it is indicated that incorporation of the results of OR and PR immunocytochemistry into a prognostic index may lead to a better identification of different risk groups.

\section{Introduction}

Overall five year-survival for patients with endometrial cancer is high when compared to patients with other gynaecological tumours. However, although most patients present with early stage cancer, approximately $25 \%$ of stage I patients will die from recurrent disease (1). To improve overall results without increasing unnecessary morbidity, new specific parameters relevant for long term survival have to be developed to individualize the treatment.

Clinical and histopathological parameters have been recognized as prognostic factors in endometrial cancer. The extent of disease, as classified by the revised FIGO-staging criteria (2) after surgery, is strongly related with survival (3). Tumour type is clearly associated with prognosis, but approximately $90 \%$ of the endometrial tumours is of the common endometroid adenocarcinoma type (4). Histological differentiation also has prognostic value, although grade assessment is not always well reproducible; different pathologists may obtain considerable variability in their assignment $(5,6)$. Thus, these histopathological factors may still be insufficient to discriminate between groups differing in survival rate. More specific criteria based on further analysis of the tumour specimen have to be developed.

In recent years, a number of studies has established the prognostic value of steroid 
hormone receptor analysis in endometrial cancer (7-12). However, significant discrepancies have been reported which are mainly based on drawbacks of the radiochemical cytosol technique (13-15). Immunocytochemical sterotd receptor analysis is superior to the radiochemical assay on tissue cytosol as it allows reliable assessment of receptor expression at tumour cell level (16-18). To obviate its relevance for prognosis, immunocytochemical steroid receptor analysis should be related to long term follow-up data.

The purpose of the present study was to relate clinical and histopathological parameters, including immunocytochemical oestrogen (OR) and progesterone receptor (PR) expression in tumour epithelium, with long term follow-up in a study population of 169 patients with endometrial carcinoma. Multivariate analysis was performed using the Cox regression model to evaluate the relative prognostic value of the different variables.

\section{Materials and methods}

\section{Clinical data}

All 185 patients, consecutively treated for uterine corpus cancer (at the De Wever Hospital Heerlen) from January 1977 to December 1987, were studied retrospectively. After exclusion of 11 non-malignant specimens (atypical hyperplasia) and 5 sarcomas, a series of diagnostic curettage and/or biopsy samples from 169 patients with a pathologically-confirmed diagnosis of endometrial carcinoma was analysed by immunocytochemistry for OR and PR expression. Age ranged from 19 to 85 years (median 61 years). Clinical staging was based on fractional curettage and/or biopsy and was determined according to pre-1988 FIGO guidelines (19).

Treatment of FIGO stage I-III patients consisted primarily of total abdominal hysterectony with bilateral salpingo-oophorectomy. Five patients underwent vaginal hysterectomy with bilateral oophorectomy because of a poor physical condition. No preoperative radiotherapy was administered. Pathological staging was established by intra-operative observations and histopathological examination of the extirpated specimen (20). Subsequent adjuvant radiotherapy in patients with pathological stage I carcinoma revealing superficial $(<1 / 2)$ myometrial tumour invasion $(n=84)$, consisted of irradiation of the upper vagina by Cs.137-ovoids ( 30 Gy in 24 h) using the afterloading technique. Patients with stage I disease and deep $(\geq I / 2)$ myometrial tumour invasion and/or grade III tumours $(n=53)$, and patients with stage II $(n=8)$ or III $(\mathrm{n}=1.5)$ cancer were treated by irradiation of the upper vagina by $\mathrm{Cs}^{137}$-ovoids (10 Gy in $8 \mathrm{~h}$ ) using the afterloading technique, which was followed by external pelvic irradiation (40-50 Gy in 20-25 fractions). One stage III and eight stage IV patients were treated on an individual, palliative basis: either with surgery $(n=5)$, or with a combination of surgery and radiotherapy $(n=2)$, or with hormonal therapy 
only $(\mathrm{n}=2)$. Irrespective of tumour steroid receptor status, hormonal therapy consisted for all patients of $200 \mathrm{mg}$ gestonoron-capronate injections (Depostat ${ }^{\mathrm{R}}$, Schering. The Netherlands): twice weekly between the diagnostic procedure and surgery and postoperatively for four weeks, followed by weekly injections or daily oral therapy ( $300 \mathrm{mg}$ ProveraR, Upjohn International, Belgium) up to two years.

Follow-up, intentionally for 10 years, was scheduled as follows: every three months during the first and second year, every six months the next three years and annually afterwards. The censorship date for this study was January 1991. The mean follow up period for the patients was 62 months, with a range of 1 to 144 months.

\section{Histological data}

Microscopic slides from all diagnostic curettages or biopsies and hysterectomy specimens were reevaluated by two pathologists by consensus for histological tumour type and grade, without knowledge of the clinical or steroid receptor status. The histological tumour type classification used, was that recommended by the International Society of Gynecological Pathologists (4). Histological grading was performed according to the revised FIGO definitions (2). For statistical analyses, the histological tumour types were divided into two groups: conventional endometroid adenocarcinoma ( $\mathrm{n}=141)$, and adenoacanthoma $(\mathrm{n}=20)$ or carcinoma revealing uncommon features ( $\mathrm{n}=8$ : adenosquamous, $\mathrm{n}=1$; serous papillary, $\mathrm{n}=1$; clear cell, $\mathrm{n}=3$; squamous $\{21\}, \mathrm{n}=2$; undifferentiated, $\mathrm{n}=1$ ). The histological grades were also divided into two groups: well-differentiated (grade $I, n=140$ ), and moderatelyor poorly-differentiated (grade II or III, $n=29$ ) carcinomas.

\section{Steroid receptor immunocytochemistry}

Steroid receptor immunostaining and quantification of receptor expression, as determined by the percentage positive area ( $\%$ Pos. Area), were performed as reported previously $(20,22)$. As $\%$ Pos. Area is a continuous variable, the range of 169 scores for $\mathrm{OR}$ and $\mathrm{PR}$ was divided arbitrarily and prior to statistical analyses into four categories of (approximately) the same size. The scoring categories defined by these quartiles were as follows: for OR absent or very low $(<16 \%, \mathrm{n}=40)$, low $(16-33 \%, \mathrm{n}=42)$, moderate $(33-47 \%, \mathrm{n}=43)$ or strong $(>47 \%, \mathrm{n}=44)$ immunoreactivity. For $\mathrm{PR}$ absent or very low $(<6 \%, \mathrm{n}=40)$, low $(6-19 \%, \mathrm{n}=43)$, moderate $(20-33 \%, n=44)$ or strong $(>33 \%, n=42)$ immunoreactivity.

\section{Statistical analysis}

Survival time (defined as the time between date of diagnosis and death from disease) was used as follow-up variable. Deaths of intercurrent disease were considered censored observations. Survival curves were determined with the Kaplan-Meier 
product limit technique based on the most recent clinical status. Differences between survival curves were evaluated by the logrank test. The relative effects of clinical and histopathological variables on survival were analysed using Cox's proportional hazards regression model. All tests were carried out with the BMDP statistical package using the program's life tables and survivor functions (11, 1990 version)

\section{Results}

For all stages, overall five year-survival was $76 \%$, and $83 \%$ when corrected for deaths due to intercurrent disease. Of the 169 patients studied, 28 died of disease $(16.5 \%)$. In 20 out of $160(12.5 \%)$ patients with pathological stage I,II or III endometrial carcinoma who were treated with a curative intention, recurrent cancer was diagnosed during follow-up. For these 20 patients median time to recurrence was 20.5 months and median survival time 26 months; ultimately, all 20 patients died of endometrial cancer. With respect to the pathological stage at initial diagnosis, recurrences were distributed as follows: fifteen stage II (11\%), two stage II (25\%) and three stage III (20\%) tumours. One patient with advanced stage III and seven out of eight $(87.5 \%)$ patients with pathological stage IV cancer who received individualized palliative treatment, died of endometrial cancer.

In Table 1, logrank test analysis of survival is presented for multiple clinical and histopathological factors including quantitation of OR and PR immunostaining of the malignant epithelial component. Univariate analysis revealed significant effects on survival for FIGO stage, pathological stage, depth of myometrial invasion, histological grade, and immunoreactivity scores as indicated by \% Pos. Area for OR as well as PR.

Multivariate analysis of various parameters was performed to evaluate the relative effects of prognostic factors on survival. As is shown in Table 2, Cox"s proportional hazards model revealed that both OR and PR immunoreactivity scores were strongly associated with survival when compared to other clinical and histopathological factors. The relative risks of dying of endometrial carcinoma for patients with lowest categories OR $(<16 \%$ Pos. Area) or PR $(<6 \%$ Pos. Area) immunoreactivity in the diagnostic specimen were 4.3 and 4.6 respectively, versus the patients with higher categories of receptor staining as reference groups.

In 137 patients with pathological stage I disease, overall five year survival was $83 \%$, and $89 \%$ when corrected for deaths due to intercurrent disease. Figs. Ja and b show the survival curves according to the grouped OR and PR immunostaining categories of the tumour specimens. Patients with a pathological stage I endometrial carcinoma revealing absent or very low OR $(<16 \%$ Pos. Area) or PR $(<6 \%$ Pos. Area $)$ expression showed a highly significant lower percentage of survival than patients with 
Table 1. The arsociation of surviwal with clinical and histopathological factors in 169 patients with endometrial carchoma

\begin{tabular}{|c|c|c|c|c|}
\hline wanable & $n$ & $\begin{array}{c}\text { estimated } 5 \text { year } \\
\text { survival }(\%)\end{array}$ & $\log x$ & ank test \\
\hline \multicolumn{5}{|l|}{ roO stage } \\
\hline 1 & 157 & 87 & & \\
\hline II & 3 & 100 & & \\
\hline III & 3 & 0 & & \\
\hline $\mathrm{IV}$ & 6 & 0 & $<$ & 0.0001 \\
\hline \multicolumn{5}{|l|}{ pathological stage } \\
\hline 1. & 137 & 89 & & \\
\hline II & 8 & 75 & & \\
\hline III & 16 & 75 & & \\
\hline IV & 8 & 13 & $<$ & 0.0001 \\
\hline \multicolumn{5}{|c|}{ myometrial invasion \# } \\
\hline$<0.5$ & 90 & 93 & & \\
\hline$\geq 0.5$ & 77 & 72 & & 0.0006 \\
\hline \multicolumn{5}{|l|}{ tumour type } \\
\hline adeno & 141 & 82 & & \\
\hline acanthoma & 20 & 95 & & 0.3 \\
\hline uncommon & 8 & 75 & & \\
\hline \multicolumn{5}{|l|}{ histological grade } \\
\hline 1 & 111 & 90 & & \\
\hline II & 42 & 67 & & 0.01 \\
\hline IIII & 16 & 75 & & \\
\hline \multicolumn{5}{|c|}{ OR immunoreactivity } \\
\hline strong & 44 & 98 & & \\
\hline moderate & 43 & 97 & & \\
\hline low & 42 & 84 & & \\
\hline absent or very low & 40 & 51 & $<$ & 0.0001 \\
\hline \multicolumn{5}{|c|}{ PR immunoreactivity } \\
\hline strong & 43 & 100 & & \\
\hline moderate & 42 & 90 & & \\
\hline low & 44 & 92 & & \\
\hline absent or very low & 40 & 49 & $<$ & 0.0001 \\
\hline \multicolumn{5}{|c|}{ Hin two parients the uterus was not removed } \\
\hline
\end{tabular}


Table 2. Summary of the results of the Cor's proportional hazards model analysis for prognowno factors in 169 (all srage) endometrial cancer patients

\begin{tabular}{|c|c|c|c|c|}
\hline foctor & coefficient & $S E$ & relarine risk & $\begin{array}{c}\text { lolkelihood } \\
\text { ratio test } \\
\text { p value }\end{array}$ \\
\hline PR absent or very low & $1.5 \|$ & 0.55 & 4.6 & 0.006 \\
\hline OR absent or very low & 1.45 & 0.57 & 4.3 & 0.007 \\
\hline pathological stage > I & 1.23 & 0.47 & 3,4 & 0.01 \\
\hline myomerrial invasion $\geq 1 / 2$ & 0.79 & 0.48 & 2.2 & 0.086 \\
\hline histological grade > I & 0.22 & 0.47 & 1.3 & 0.6 \\
\hline tumour type: non-adeno & -1.66 & 0.64 & 0.2 & 0.003 \\
\hline
\end{tabular}

Table 3. Summary of the results of the Cox's proportional hazards model analysis for prognostic. factors in 137 pathological stage I endometrial cancer patients

\begin{tabular}{lcccc}
\hline factor * & coefficient & $S E$ & relative risk & $\begin{array}{c}\text { likelihood } \\
\text { ratio test } \\
\text { Pvalue }\end{array}$ \\
\hline PR absent or very low & 1.55 & 0.7 & 4.7 & 0.021 \\
OR absent or very low & 1.43 & 0.64 & 4.2 & 0.020 \\
myometrial invasion $\geq 1 / 2$ & 1.17 & 0.62 & 3.2 & 0.049 \\
histological grade $>$ I & 0.52 & 0.56 & 1.7 & 0.348 \\
& & & & \\
* for statistical analyses, a transformation into large categories was applied &
\end{tabular}

Tabte 4. Prognostic factors at diagnosis and sites of recurrence in 15 patients with pathological stage I endometrial cancer

\begin{tabular}{|c|c|c|c|c|c|c|c|c|c|}
\hline \multirow{3}{*}{$\frac{n}{4}$} & \multirow{3}{*}{$\begin{array}{l}\text { depth of } \\
\begin{array}{l}\text { myometriat } \\
\text { invasion }\end{array} \\
<1 / 2\end{array}$} & \multicolumn{2}{|c|}{ tumour } & \multirow{2}{*}{\multicolumn{2}{|c|}{$\begin{array}{l}\text { \% Pos. Area OR } \\
\text { median (range) }\end{array}$}} & \multirow{2}{*}{\multicolumn{2}{|c|}{$\begin{array}{l}\text { \% POs. Area PR } \\
\text { median (range) }\end{array}$}} & \multirow{2}{*}{\multicolumn{2}{|c|}{$\begin{array}{l}\text { site of redurence } \\
\text { local distant }\end{array}$}} \\
\hline & & type & grade & & & & & & \\
\hline & & adeno & II & 1 & $(0-19)$ & 0 & (0) & 4 & 1 \\
\hline 8 & $\geq 1 / 2$ & adeno & I & 15 & $(0-50)$ & 0 & $(0-27)$ & 2 & 6 \\
\hline 3 & $\geq 1 / 2$ & adeno & II & 0 & $(0-20)$ & 0 & $(0-6)$ & 1 & 3 \\
\hline
\end{tabular}



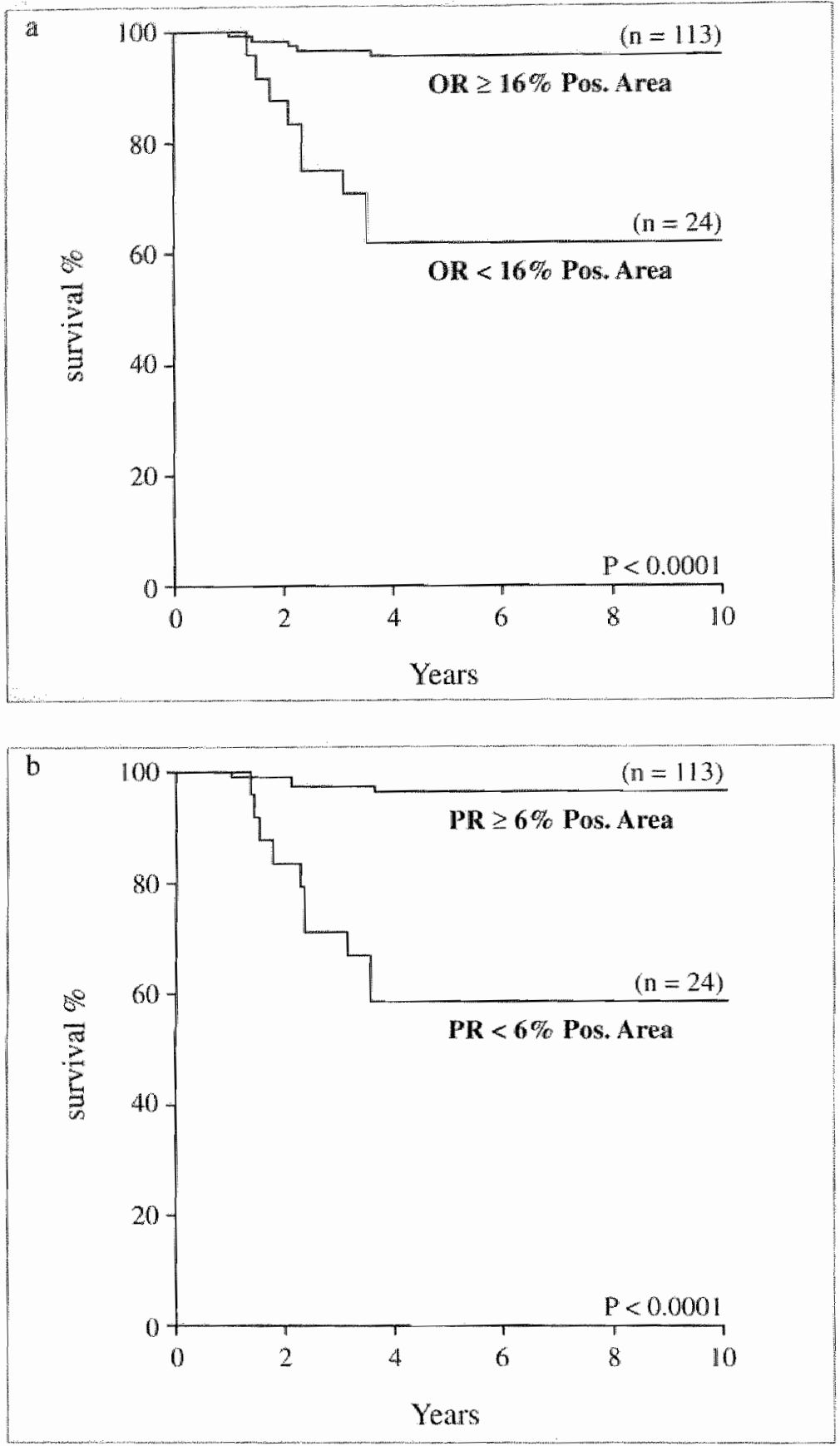

Fig. 1. Kaplan-Meier sumval curves for 137 patients whih different $O R$ (a) and PR (b) iwhumoneactivity categories in pathological stage l endomertial cancer. 
neoplasms revealing low, moderate, or high OR or PR expression. The results of Cox regresision analysis of prognostic factors in 137 patients with pathological stage 1 endometrial cancer are presented in Table 3. OR and PR immunoreactivity and depth of myometrial invasion added significant prognostic information to long term survival.

Table 4 summarizes prognostic factors and site of recurrence in the 15 patients with a pathological stage I endometrial carcinoma at diagnosis, who were found with recurrent cancer during follow-up. At the moment of diagnostic procedure, $O R$ and PR expression was absent or very low in five out of eight well-differentiated (grade I), and in six out of seven moderately-differentiated (grade II) carcinoma specimens. Recurrences were observed in four out of $84(5 \%)$ patients revealing superficial myometrial invasion $(<1 / 2)$ at diagnosis. Apart from lung metastases in one patient, local pelvic recurrence was diagnosed in all four patients. In 53 patients with deep myometrial invasion $(\geq 1 / 2)$ or a histological grade liI tumour at diagnosis, $11(21 \%)$ recurrences were encountered during follow-up; in these patients a majority (9/11) of distant recurrences was observed.

\section{Discussion}

Several studies have noted the relation between radiochemical steroid receptor status and survival of patients with endometrial carcinoma (7-12). In these studies, which all used different receptor cut-off levels, the presence or absence of OR and/or PR in the tumour tissue homogenate was a significant prognostic factor. Steroid receptor analysis using immunocytochemistry allows receptor localization and (semi)quantitation at the level of the tumour cell. Several studies on steroid receptor immunocytochemistry in endometrial cancer have now been published $(17,18,22,23)$, but only one has dealt with the prognostic value of receptor immunocytochemistry (24). We found that both $\mathrm{OR}$ and PR immunoreactivity have significant prognostic value in endometrial cancer. This is partly in concordance with the results of Chambers et al. (24), who reported prognostic relevance of the immunocytochemical OR status only. However, several important differences between the studies have to be taken into consideration. In the study of Chambers et al. (24). treatment was based on preoperative clinical FIGO staging (19). Preoperative radiotherapy (intracavitary brachytherapy) was routinely administered which may interfere with histopathological evaluation of the operative specimen (25). Mean follow-up was 30 months, in contrast to 62 months in our study. In contrast to the scoring of receptor staining by an observer as reported by Chambers et al. (24), we used computerized image analysis which is more objective and results in a good discrimination of the different prognostic groups $(26,27)$.

Several studies have examined prognostic factors in early stage endometrial cancer, but few have attempted to evaluate the relative influence of these on survival 
$(3,7,24,28)$. Previously, we have reported that the immunocytochemical steroid receptor quantitation is strongly associated with several clinical and histopathological prognostic factors. In the present study, multivariate analysis indicates that both OR and PR imnunoreactivity scores of uterine tumour cells are of substantial value for predicting survival. Hence, it is suggested that OR and PR immunocytochemistry is of significant importance in a prognostic index to identify the different risk groups.

In pathological stage I endometrial carcinoma, absent or very low OR and PR immunoreactivity of the tumour epithelium was important as predictor of recurrence and poor survival. The recently revised FIGO guidelines stress the importance of surgicalpathological staging as an indicator for additional therapy (2). In this respect, radiotherapy has always been the cornerstone of adjuvant treatment for advanced stage II-IV corpus cancer $(25)$. However, most patients ( $>75 \%$ ) present with early stage I disease. There is still debate on the choice of adjuvant therapy for these patients (25). In our study, the mode of adjunctive radiotherapy was based on postoperative pathological staging. In pathological stage I tumours with only superficial $(<1 / 2)$ myometrial invasion, irradiation of the upper vagina was performed. A $5 \%$ (4/84) recurrence rate was observed. It was striking that all four recurrent turnours showed absent or very low OR and PR immunoreactivity at the moment of diagnostic curettage, except for one tumour revealing low OR expression. Apparently, absent or minimal steroid receptor expression, albeit in superficially invading stage I tumours, may predict aggressive tumour behaviour.

Combined internal and external radiotherapy was administered when stage I tumours showed either deep $(\geq 1 / 2)$ myometrial invasion or poor differentiation (grade III). However, in spite of a more aggressive therapy, $2 \| \%(11 / 53)$ recurrences were reported in these pathological stage I tumours. Surprisingly, a majority (8/11) of these tumours were classified as well-differentiated (grade I). As the tumour penetrates the myometrium, access to lymphatics increases the likelihood of extrauterine dissemination $(3,29)$. In accordance with a prospective study of Aalders et al. (30), distant recurrences predominated. External radiotherapy decreases the rate of local pelvic recurrence but does not improve survival $(25,30)$. Systemic adjuvant therapy may be needed to improve survival for patients with these high-risk tumours. As absent or very low OR or PR immunoreactivity was strongly indicative for treatment failure, steroid receptor immunocytochemistry may be a helpful tool in the guidance of treatment.

In conclusion, steroid receptor immunocytochemistry has appeared to be significant for the prediction of survival of patients with endometrial carcinoma. Absent or very low OR and PR immunoreactivity indicated a significantly lower survival rate in all stages. With respect to clinical management, receptor analysis may be highly valuable for stage I patients in particular. Of course, it remains to be established that incorporation of receptor immunocytochemistry results into treatment planning will improve survival rates. Prospective studies introducing systemic therapies are needed to evaluate this hypothesis. 


\section{Acknowledgements}

We are indebted to Marij Debets-Te Baerts for expert immunocytochemistry, and to Marion de Leeuw and Ineke van Lijnschoten for valuable help with statistical analyses of the results. This study was partly supported by a grant from the Nijbakker Morra Stichting.

\section{References}

1 FIGO. Annual report on the results of treatment in gynecological cancer. Vol 21. Petterson F, ed. Stockhoim, Radiumhemmet 1991

2 Shepherd JH. Revised. FIGO staging for gynaecological cancer. Br J Obstet Gynaecol 1989 , 96:889-892

3 Morrow CP, Bundy BN, Kurman RJ et al. Relationship between surgical-pathological risk factors and outcome in clinical stage 1 and II carcinoma of the endometrium: a Gynecologic: Oncology Group study. Gyn Oncol 1991, 40: 55 - 65

4 Kurman RJ \& Norris HJ. Endometrial carcinoma. In: Blaustein"s Pathology of the Female Genital Tract, 3rd ed. Kumman RJ, ed. New York, Springer-Verlatg 1987: $338-373$

5 Stoddard LD. Endometrial carcinome. Path Res Pract 1982, 174: 175-179

6 Putten van der H. Endometrial Hyperplasia and Stage I Adenocarcinoma. Thesis. Amsterdam, Schriks 1987

7 Creasman WT, Soper JT, McCarty KS Jr et al. Influence of cytoplasmic steroid receptor content on prognosis of early stage endometrial carcinoma. Am J Obstet Gynecol 1985, 151: $922-932$

8 Ehrlich CE, Young PC, Stehman FB, Sutton GP \& Alford WM. Steroid receptors and clinical outcome in patients with adenocarcinoma of the endometrium. Am J Obstel Gynecol $1988,158: 796-807$

9 Chambers JT, Macluskey N, Eisenfield A, Kohorn EI, Lawrence R \& Schwartz PE. Estrogen and progestin receptors as progmosticators for survival in endometrial cancer. Gyn Oncol 1988, 3: $65-77$

10 Palmer DC, Muir IM, Alexander Al, Cauchi M, Bennett RC \& Quinn MA. The prognostic importance of steroid receptors in endometrial carcinoma. Obstet Gynecol 1988 , $72: 388-393$

11 Sockwell Ingram S, Rosenman J, Heath R, Morgan TM, Moore D \& Varia M. The predictive value of progesterone receptor levels in endometrial cancer. Int J Radiation Oncology Biol Pliys $1989,19: 21-27$

12 Kleine W, Mailer T, Geyer H \& Pfleiderer A. Estrogen and progesterone recepiors in endometrial cancer and their prognostic relevance. Gyn Oncol 1990, 38:59-65

13 Lindahl B, Am P, Fernö M, Grundsell H, Norgren A \& Tropé C. Relapse of endometrial carcinoma related to steroid receptor concentration, staging, histological grading, and myometrial invasion. Anticancer Res 1986, 6:1317-1320

14 Utaaker E, Iversen OE \& Skaarland E. The distribution and prognostic implications of steroid receptors in endometrial carcinomas. Gyn Oncol 1987, 28: 89-100

15 Quinn MA, Cauchi M \& Fortune D. Endometrial carcinoma: Steroid receptors and response to medroxyprogesterone acetate. Gynecol Oncol $1985,21: 314 \ldots 319$ 
16 Parl ITF Posey YF. Discrepancies of the biochemical and immunohistochemical estrogen receptor assays in breast cancer. Hum Pathol $1988,19.960-966$

17 Snifders MP, De Goeff AF, Koudstaal Joh et al. Is immunonistochemical analysis of oestrogen and progesterone receptors in endometrial carcinoma superior to the radioligand binding assay? I Pathol 1990, 161:129-135

18 Soper JT, Segreti EM, Novotny DB, Mutch D, Creasman WT \& McCarty KS Jr. Estroger and progesterone receptor content of endometrial carcinomas: comparison of total tissue versuss cancer component analysis. Gyn Oncol 1990; 36:363- 368

19 Disaia PJ Creasman WT. Staging (appendix A). In: Clinical Gynecologic Oncology, 3rd ed. Bircher S \& Gunther A, ads. St. Louis, C.V. Mosby 1989: 647 - 649

20 Snijders MP, De Goell AF, Volovics A et all. Preoperative oestrogen and progesterone receptor immunocytochemistry in endometrial carcinoma: correlation with clinical and histopathological parameters. Submitted for publication

21 Sluymer AV, Ubachs JMH, Stoot JE, Steyer M \& Koudstaal Joh. Clinical and pathological aspects of benign and malignant squamous epithelium of the corpus uteri; a report of two cases. Eur J Obstet Gynecol Biol Reprod 1991, 39:71 - 75

22 Snijders M* De Goeij AF, Thunnissen E, Koudstaal Joh, de Haan J \& Bosman FT. Oestrogen and progesterone receptor immunocytochemistry in hyperplastic and neoplastic human endometrium. I Pathol 1992, 166:171-177

23 Budwit-Novotny DA, McCarty KS, Cox EB et al. Immunohistochemical analysis of estrogen receptor in endometrial adenocarcinoma using a monoclonal antibody. Cancer Res 1986, 46: $5419-5425$

24 Chambers JT, Carcangiu ML, Voynick IM \& Schwartz PE. Immunohistochemical evaluation of estrogen and progesterone receptor content in 183 patients with endometrial carcinoma. Part II: correlation between biochemical and immunohistochemical methods and survival. Am J Clin Pathol 1990, 94:255 - 260

25 Underwood PB \& Taylor PT. Endometrial carcinoma; the role of irradiation. In: Endometrial Cancer, Creasman WT ed. Clinics in Obstetrics and Gynaecology. London, WB Saunders $1986,16: 767-788$.

26 Bacus S, Flowers JL, Press MF, Bacus JW \& McCarty KS. The ewaluation of estrogen receptor in primary breast carcinoma by computer-assisted image analysis. Am J Clin Pathol $1988,90: 233-239$

27 McClelland RA, Wilson D, Leake R, Finlay P \& Nicholson RI. A multicentric study into the reliability of steroid receptor immunocytochemical assaty quantification. Eur J Cancer $1991,27: 711-715$

28 Sutton GP, Geisler HE, Stehman FB, Young PC, Kimes TM \& Ehrlich CE. Features associated with survival and disease-free survival in early endometrial cancer. Am J Obstet Gynecol 1989, 160: 1385-1393

29 Borronow RC, Morrow CP, Creasman WT et al. Surgical stiging of endometrial cancer: chinical pathologic findings of a prospective study. Obstet Gynecol 1984, 63:825-832

30 Aalders JG, Abeler V, Kolstad P \& Onsrud M. Postoperative external irradiation and prognostic parameters in stage I endometrial carcinoma. Clinical and histopathologic study of 540 patients. Obstet Gynecol 1.980, 56:4.19- 427 


\section{CHAPTER 8}

\section{General Discussion}




\subsection{Introduction}

The sex steroid hormones oestrogen and progesterone and their receptors are pivotal to the endocrine regulation of growth and differentiation of uterine tissues, both under physiological and pathological conditions. Hence, the analysis of oestrogen $(\mathrm{OR})$ and progesterone (PR) receptors in proliferative disorders of the endometrium may give essential information on their biological behaviour. Apart from providing knowledge on pathogenesis and prognosis, steroid receptor analysis may yield a tool for the development of more individualized treatment protocols for uterine (pre)malignancy.

In this thesis, we initially validated the immunocytochemical OR and PR analysis for use on uterine samples. Furthermore, in order to obtain more insight into the endocrine mechanisms operative at the (inter)celiular level, immunocytochemistry was used to study OR and PR distribution in the various cell types of normal, hyperplastic, and neoplastic endometrium. Finally, the clinical value of $O R$ and $P R$ analysis of the tumour cells was evaluated in a series of 169 endometrial cancer patients.

\subsection{Semiquantitative immunocytochemical analysis of steroid receptors in uterine tissue}

In the "classical" radiochemical binding assay, the receptors are quantitated by measuring the high-affinity specific binding of a radiolabelled ligand to homogenised preparations of tissue (1). Immunochemical detection is based on recognition of an epitope on the receptor molecule by a monoclonal antibody (2). In immunocytochemistry, the distribution and the intensity of staining are used for semiquantitative receptor analysis (3-5). Good agreement between immunocytochemical and radioligand binding assay for steroid receptors was found in many correlative studies on breast cancer (5-7). For uterine tissue however, the comparison between the two different methods of receptor analysis is less well documented, and only recently several studies on a larger series of endometrial specimens have been published $(3,8,9)$. Non-malignant tissue elements such as normal glands, stroma, and myometrium are frequently present in endometrial carcinoma samples and they usually contain appreciable amounts of steroid receptors $(10,11)$. Therefore, the comparison between radiochemical and immunocytochemical assays in our study was performed on adjacent tisste sections.

This approach indeed revealed extensive heterogeneity in tissue composition, as well as in receptor distribution over the various cell types. Absence of knowledge on the tissue composition and quality (e.g. necrosis) in the radiochemical cytosol assay forms clearly a drawback of this method. On the other hand, false negative results 
will be found in the immunocytochemical receptor assay when the epitope is masked or destroyed by tissue processing. Furthermore, the immunostaining intensity may not be linearly correlated with the concentration of the epitope (i.e. receptor) in the cell. This leads to the conclusion that, for reliable interpretation of the radioligand binding assay of endometrial samples, additional histological control is a prerequisite. Considering the data from the correlative studies presented in this thesis and others $(3,6,9,11-15)$, the immunocytochemical receptor analysis is considered to be superior to the radioligand binding assay.

Optimal tissue preservation is essential for interpretation of the meticulous cellular changes during the menstrual cycle and neoplastic transformation. The use of paraffin sections has important advantages over cryostat sections such as better histomorphology, application of routine tissue-processing procedures, and last but not least it allows retrospective analysis on a large scale to be correlated with clinical data. This study demonstrated that both OR and PR epitopes can be reliably detected in sections of routinely formalin-fixed, paraffin-embedded uterine samples. The results are in good agreement with several other, recently published studies $(8,16-18)$. However, for reliable interpretation of immunocytochemical receptor studies the procedures for tissue processing, immunostaining and the (semi) quantitative scoring should be strictly standardized within and between laboratories. Before application of the results in clinical practice, quality control programs for immunocytochemical receptor assay are urgently needed $(19,20)$.

With respect to (semi)quantitation, the receptor scoring in this study was performed either by one or two observers using classification of staining distribution in combination with staining intensity (3-5), or by computerized image analysis (2022). The visually obtained receptor scores showed low intra- and interobserver variability. However, considering recently performed multicentre studies $(19,20)$, it should be emphasized that marked discordances can occur in visually scored receptor values.

Computerized image analysis, using a twomcolor mask imaging technique, was applied to reduce bias caused by subjective interpretation. The reproducibility of percentage positive area-measurements was satisfactory. However, although this automated scoring-method gives more objective and reproducible analyses of immunostained tissue sections, some pitfalls must be kept in mind. Immunostaining is subject to variation and significant non-specific staining may occur. To overcome these problems, visual adjustment of the so called 'antibody treshold", used to discriminate between positive and negative cells, is necessary from specimen to specimen (21). This interactive adjustment introduces a subjective element into computerized image analysis. Our results and those of others (20-22) indicate, that image analysis provides a rather efficient and objective means of evaluating the receptor content in uterine tissue sections.

In addition, when a number of fields is analysed in tissue sections, the variation coefficient of the mean receptor content gives an impression of the distribution of the receptor over the tumour and of differences in staining intensity between the 
cells, and thus assesses tumour heterogeneiry (23). Heterogeneity of receptor may be related to the phenomenon that cancers which are initially responsive to hormonal treatment, are recurring as receptor-negative tumours after several years. These recurrences, often refractory to endocrine treatment, could result from an overgrowth of receptor-negative tumour cells present in the original tumour.

In conclusion, immunocytochemistry may replace the radioreceptor assay in the near future as it allows receptor visualization and (semi)quantitation at tumour cell level. Of course, tissue handling, immunostaining and receptor quantification have to be optimized and standardized, before steroid receptor immunocytochemistry can be introduced into daily clinical practice. A quality control program should accompany the introduction of this technique.

\subsection{Immunocytochemical steroid receptor analysis in normal and (pre)neoplastic endometrium}

Does immunocytochemical OR and PR analysis provide information relevant for the prediction of biological behaviour of normal and tumour cells in endometrium? The assessment of steroid hormone concentration in serum and target tissue samples provides valuable, but limited information with regard to hormonal effects on endometrial growth and differentiation. Considering the heterogeneous cellular composition of the uterus, the effects of hormones are better studied at the cellular level. This can be done by analysing $O R$ and PR by immunocytochemistry; this technique however, reveals only the cellular potential of responsiveness to steroid hormones, not the effect itself.

Differential patterns of immunocytochemical OR and PR expression were observed in the various uterine cell types in normal and (pre)neoplastic conditions. In the normal uterus, OR and PR immunostaining patterns differed between the glandular epithelium and stroma of the endometrium during the various phases of the menstrual cycle. Atypical hyperplasia and well-differentiated adenocarcinoma both revealed a relative loss of stromal PR content as compared to persistent expression of OR in stroma and of OR and PR in the epithelial cells. Alsbach et al. (24) and Vermeulen-Meiners et al. $(25,26)$ have reported tissue accumulation of $E_{2}$ during the proliferative phase of the menstrual cycle and in the various proliferative disorders of the endometrium, but no consistent relation with histomorphological changes was noted. Studies on stromal-epithelial interactions (27-31) strongly suggest that local hormone-controlled mechanisms in and between stromal and epithelial cells are operative in the normal and (pre)neoplastic endometrium. Also, the recent reports providing ultrastructural evidence for intercellular contacts between stromall and epithelial cells support these findings $(32,33)$. It is indicated that growth, differentiation, 
and invasive behaviour of (atypical) epithelial cells is directly governed by steroid hormones as well as indirectly mediated via endocrine-related stromal factors.

Recently, Vollmer et al. (34) reported their findings on tenascin, an extracellular matrix glycoprotein (35), which appears an oestrogen-stimulated endometrial stromal factor modulating epithelial tumour cell invasion. In cases of hyperplasia, tenascin immunolocalized throughout the extracellular space of the stroma and the staining intensity was increased as the hyperplasia became more atypical. Based on our receptor findings and endometrial stromal-epithelial cell interactions which appear to be stimulated by oestrogens $(32,33,36)$, it is suggested that oestrogen-related malignant transformation of endometrial hyperplasia is promoted via stromal factors. From breast cancer research, it has become clear that prolonged oesirogen stimulation may lead to 'defective' OR function: instead of physiological oestrogen effects (leading a.o. to PR protein synthesis) oncogenes may be potentiated. In this respect the observed 'early' loss of stromal PR expression may be indicative of malignant transformation, a finding which was confirmed in hyperplastic specimens containing atypical hyperplastic lesions and a large series of endometrial carcinomas. It seems likely that development of endometrial carcinoma involves loss of coordination and significant aberrations in the interaction between epithelial and stromal elements in the tissue. Further studies incorporating growth factors, oncogenes and extracellular matrix elements as tenascin and collagen type IV and VII (37) are required to validate this hypothesis on malignant transformation of endometrial hyperplasia(*).

In a clinical perspective, OR and PR levels thave been reported to be lowered in the endometrium of patients with luteal phase deficiency (38-40), of patients treated with clomiphene citrate (41), and in endocervical glands of infertile women with poor cervical mucus (42). As in such patients normal serum steroid levels do not preclude these problems, local endocrine disorders may be the cause of the reproductive failure. Receptor immunocytochemistry gives more detailed information on local steroid-hormone response potential at the cellular level, and thus may become a diagnostic tool in the investigation of infertility, as suggested by Garcia et al. (43). Of course, before steroid receptor immunocytochemistry of luteal phase biopsies is introduced into clinical practice, more extensive studies should be performed with exact monitoring of the moment of ovulation to assess the normal range of receptor scores for the various cell types during the different menstrual cycle phases. In this clinical context, our study on normal endometria must be considered as directive.

Endometrial hyperplasia, atypical hyperplasia, and adenocarcinoma are defined as a morphological continuum causally related to 'unopposed' oestrogen exposition and characterized by increasing complexity of glandular architecture, atypia of the glandular epithelium and stromal invasion (44). Endometrial hyperplasias have been considered as preneoplastic disorders per se. This is illustrated by Halban's adagium "nicht Karzinom, aber besser heraus" and indeed, many patients have undergone hysterectomy only as cancer prevention (45). However, endometrial hyperplasias form a heterogeneous group of abnormalities. As only a fraction of the hyperplasias harbours a significant risk of malignant transformation and progestational therapy 
may cure most of them $(46,47)$, hysterectomy may be serious overtreatment for many patients. Obviously, better criteria are needed to indicate the endocrine relationships of these proliferative disorders with respect to their prognosis and choice of treatment. In our studies, epithelial PR expression appeared to be significandy lower in atypical hyperplasia than in hyperplasia without atypia. As a high PR content is strongly indicative for a positive response to progestational herapy, spectic immunocytochemical analysis of PR content of epithelial as well as stromal cells may be relevant for the choice of therapy for endometrial (atypical) hyperplasias. With this tool, overtreatment of endometrial proliferative disorders should be diminished; prospective studies are needed to validate this hypothesis.

\subsection{Clinical relevance of steroid receptor immunocytochemistry in endometrial cancer}

In endometrial cancer management, prognostic factors appear more and more important to predict tumour behaviour and bence to guide an individualized choice of treatment. Sensitive and specific noninvasive tests, which can predict extrauterine metastases in low stage cancer preoperatively, allow selection of patients who will most likely benefit from comprehensive surgical staging procedures (e.g. pelvic and paraaortic lymphadenectomy). A thorough investigation of tumour characteristics in the preoperative specimen seems to be a more balanced approach than routinely performed extended surgical staging, which leads to serious overtreatment-related morbidity and mortality $(48,49)$.

In the present study, absent of very low OR or PR expression in the diagnostic curettings was strongly associated with adverse clinical and histopathological prognostic factors. Furthermore, very low or absent receptor immunoreactivity was correlated with metastatic disease in $40 \%$ of the cases with clinical stage I disease. These results imply that patients with a tumour clinically confined to the uterus and with (very) low or absent OR or PR levels before therapy, are at higher risk for extraterine extension of cancer. These patients thus may potentially benefit from treatment protocols designed for more extensive disease. In our study howewer, the sensitivity and specificity of (very) low ot absent OR and PR expression are too low to justify acceptance of steroid receptor immunocytochemistry as the sole predictor of (occult) metastatic spread. But, as steroid receptor immunocytochemistry can now be performed on routinely-fixed, paraffin-embedded curettage specimens, a combination of clinical and histopathological factors (e.g. tumourtype, histological grade and receptor content) may guide more careful surgical-pathological staging. Recently, several authors have described the clinical value of serum tumour markers as preoperative indicators of cancer growth beyond the uterine corpus (49-52). To predict early metastatic spread in stage I endometrial carcinoma more reliably, 
prospective studies combining the prognostic value of several histobiological tumour characteristics appear urgently needed *.

$\mathrm{OR}$ and $\mathrm{PR}$ immnocytochemistry appeared important prognostic factors relevant to long term survival in a retrospective study of 169 endometrial carcinoma patients. Strikingly, the result of receptor scoring appeared far more important than the histological grade of the tumour. Therefore, the expression of steroid receptor proteins can be interpreted as an extra parameter of umour cell-differentiation, strongly related with tumour behaviour. Evidently, our retrospective findings must be substantiated in a larger prospective study ${ }^{(*)}$; when the results can be reproduced, steroid receptor immunocytochemistry should be incorporated in the histopathological report of endometrial cancer specimens. As already mentioned, quality control of staining procedures and quantification by objective means are essential conditions.

At present, surgery is the primary treatment of choice for patients with stage I endometrial cancer. Radiation therapy is used as an adjuvant modality based on the presence of poor prognostic factors. Tumour invasion beyond half of the myometrium and poor histological differentiation have been recognized as ominous prognostic factors which should guide a more agressive adjuvant radiotherapy (54). In this study, the recurrence rates of both 'risk groups' of stage I endometrial cancer are of a limited statistical interest because of risk factor imbalance, but analysis of the recurrence site may be instructive. All recurrences in the 'low-risk group' treated with high dose vaginal vault irradiation were locoregional. However, in spite of combined postoperative internal and external radiotherapy, $21 \%$ of the patients with pathological stage I cancer and aforementioned poor prognostic signs ("high-risk") died of recurrent cancer. Although locoregional cancer controll may have been successful, distant metastases predominated. Apparently, staging and/or the treatment was insufficient. With respect to staging, inaccurate evaluation of tumour spread at presentation may have influenced the treatment results negatively. As lymphadenectomy was not performed routinely during our study, occult metastatic spread to the pelvic or paraaortic lymph nodes may not have been noticed. With respect to treatment, it must be clear that the value of postoperative radiotherapy for "low-risk" as well as "high-risk" stage I endometrial carcinoma is still a matter of controversy $(54,55)$. Furthermore, radiotherapeutic treatment of paraaortic lymph node metastases (extended field) is still under debate. Just recently, Morrow et al. (56) and Boronow (57) have stressed the therapeutic value of such treatment. Morbidity and mortality of these treatment regimes may however be extensive. Prospective multicentre trials should critically evaluate the role of adjuvant radiotherapy ${ }^{\left(w^{* i}\right)}$ as well as newly developed systemic cytotoxic therapies.

Although administration of progestogens has been the standard systemic treatment for patients with metastatic disease for the past 30 years, they are effective in only $20 \%$ of the patients $(58,59)$. Steroid receptor expression in the primary tumour and/or metastatic lesions may give an indication on the chances for response to progestogens (60). Adriamycin and cisplatin are the most active cytotoxic agents; 
currently, randomized studies are evaluating these drugs (59,61-63). Maximizing the effectiveness of established drugs, and identifying alternative hormonal and cytotoxic agents with a sound scientific rationale will hopefully increase the effective treatment options for these patients. Based on the results of this study, immunocytochemical steroid receptor expression can be used as one of these scientific rationalles.

A more thorough knowledge of the regulatory pathways for growth, differentiation, and invasive behaviour is relevant for elinical management of endometrial disorders. Immunocytochemical steroid receptor analysis may provide the basis for designing new individualized treatment strategies.

" "The prognostic value of histobiological tumour characteristics in stage I endometrial carcinoma' Vroom TM, Creutzberg CL, Arends JW et al. (prospective study)

** "De waarde van postoperatieve radiotherapie bij het pTl endometriumcarcinoom" Creutzberg CL. Koper PC, Meerwaldt JH et al. (een landelijk, prospectief gerandomiseerd onderzoek)

\subsection{Final conclusions}

From the studies described in this thesis the following conclusions can be drawn:

- In view of tissue and steroid receptor heterogeneity, immunocytochemistry appears superior to the radioligand binding assay in steroid receptor analysis of uterine specimens.

- Steroid receptor analysis can be reliably performed on sections of routinely-fixed, paraffin-embedded uterine specimens.

- OR and PR expression differs between stromal and epithelial cells of the endometrium cluring the various phases of the normal menstrual cycle. The observed cyclic patterns are consistent with the hypothesis that endometrial stromal cells modulate the functional state of epithelial cells in response tot steroid hormone signalling.

- In endometrial atypical hyperplasia and adenocarcinoma, a relative loss of stromal PR content is observed when compared to persistent expression of $O R$ in the stroma and of OR and PR in the epithelial cells. It is indicated that the oestrogen-related invasive behaviour of atypical epithelial cells is mediated via stromal factors.

- Absent of very low OR or PR expression in the diagnostic specimen appears strongly associated with adverse clinical and histopathological prognostic factors in endometrial cancer, as well as with poor survival. To guide the treatment, steroid receptor immunocy tochemistry should be incorporated in the histopathological report of endometrial cancer. 


\subsection{References}

1 Baxter JD \& Funder JW. Hormone receptors. New Engl J Med 1979, 301: 1149 - 1162

2 Press MF \& Greene GL. Immunocytochemical localization of estrogen and progesterone receptors. In: Advances in Immunocytochemistry. DeLellis RA, ed. New York, Raven Press 1988: $341-361$

3 Budwit-Novotny DA, McCarty KS Sr, Cox EB et al. Immunohistochemical analyses of estrogen receptor in endometrial adenocarcinoma using a monoclonal antibody. Cancer Res $1986,46: 5419-5425$

4 Remmele $W$ \& Stegner HE. Vorschlag zur einheitlichen Definition eines Immunreaktiven Score (IRS) für den immunhistochemischen Östrogenrezeptor-Nachweis (ER-ICA) im Mammakarzinomgewebe. Pathologe 1987, 8: 138 - 140

5 Scheres HM, De Goeij AF, Rousch MJ et al. Estrogen receptor quantitication in human breast cancer: radiochemical assay on cytosol and cryostat sections compared with semiquantitative immunocytochemical analysis. J Clin Pathol 1988, 41:623-632

6 McCarty KS Jr, Miller LS, Cox EB, Konrath J \& McCarty KS Sr. Estrogen receptor analyses. Correlation of biochemical and immunohistochemical methods using monoclonal antireceptor antibodies. Arch Pathol Lab Med 1985, 109: 716 - 721

7 Lacombe MJ, Delarue JC, Mouriesse H t al. Human breast tumors: a comparison between the biochemical method of measuring estrogen and progesterone receptors and that of an immunohistochemical method. Gyn Oncol 1989, 32: 174-179

8 Chambers JT, Carcangiu ML, Voynick IM \& Schwartz PE. Immunohistochemical evaluation of estrogen and progesterone receptor content in 183 patients with endometrial carcinoma. Part II: comelation between biochemical and immunohistochemical methods and survival. Am J Clin Pathol 1990, 94: 255 - 260

9 Soper JT, Segreti EM, Novotny DB, Mutch D, Creasman WT \& McCarty KS Jr. Estrogen and progesterone receptor content of endometrial carcinomas: comparison of total tissue versus cancer component analysis. Gyn Oncol 1990, 36: 363-368

10 Mortel R, Zaïno $\mathbf{R} \&$ Satyaswaroop PG. Heterogeneity and progesterone-receptor distribution in endometrial carcinoma. Cancer 1984, 53: $113-116$

11 Soper JT, Cox EB, Budwit-Novotny D et al. Histologic composition of endomemit carcinomas analyzed for steroid receptor content. Am J Obstet Gynecol 1987, 157: 26 - 27

12 Mutch DG, Soper JT, Budwit-Novotny DA et al. Endometrial adenocarcinoma estrogen receptor content: Association of clinicopathologic features with immunohistochemical analysis compared with standard biochemical methods. Am J Obstet Gynecol 1987, 157: 924 - 931

13 Thornton JG \& Wells M. Oestrogen receptor in glands and stroma of normal and neoplastic human endonetrium: a combined biochemical, immunohistochemical, and morphometric study. J Clin Pathol 1987, 40: 1437-1442

14 Pertschuk LP, Beddoe AM, Gorelic LS \& Shain SA. Immunocytochemicat assay of estrogen receptors in endometrial carcinoma with monoclonal antibodies. Comparison with biochemical assay. Cancer 1986, 57: 1000 - 1004

15 Zaino RJ, Clarke $\mathbf{C L}$, Mortel $\mathbf{R}$ \& Satyaswaroop $\mathbf{P G}$. Heterogeneity of progesterone receptor distribution in human endometrial adenocarcinoma. Cancer Res 1988. 48: 1889-1895

16 Bur ME, Greene GI \& Press MF. Estrogen receptor locallization in formalin-fixed, paraffinembedded endometrium and endometriotic tissues. Int J Gynecol Pathol 1987, 6: 140-151 
17 Brustein 5 , Fruchter $R_{\text {; }}$ Greene GL \& Pertschuk LP. Immunocylochemical assay of progesterone receptors in partfin-embedded specimens of endometrial carcinoma and hyperplasia: preliminary evatuation. Mod Pathol 1989,2:449-455

18 Carciangitu ML, Chambiers JT, Voynick IM, Pirro M \& Schwarta PE. Immunohistological ewaluation of estrogen and progesterone receptor content in 183 patients with endometria! carcinoma. Part I: clinical and histologic correlates. Am J Clin Pathol 1990, 94: 247 - 254

19 Bosman FT, De Goeil AF \& Rousch MJ. Quality control in immunocytochemistry: experiences with the estrogen receptor assay. J Chin Pathol 1992, 45:120-124

20 McClelland RA, Wilson D, Leake R, Finlay P \& Nicholson RI. A multicentric study into the reliability of steroid receptor immunocytochemical assay quantification. Eur $J$ Cancer $1991,27: 711-715$

21 Bacus S, Fllowers JL. Press MF, Bacus JW \& McCarty KS Jr. The evaluation of estrogen receptor in primary breast carcinoma by computer-assisted image analysis. Am J Clin Pathol 1988,$90 ; 233-239$

22 Charpin $C$, Andrac L, Habilb MC et al. Immunocytochemical assays in human endometrial carcinomas: a multiparametric computerized analysis and comparison with nonmalignant changes. Gyn Oncol 1989, 33: $9-22$

23 Simony J, Pujol J-L, Grenier J \& Pujol H. Heterogeneity of estrogen receptor in primary breast carcinoma evaluated by computed image analysis. Am J Clin Pathol 1989, 92: 559 (letter)

24 Alsbach GP, Franck ER, Poortman J \& Thijssen JH. Subcellar distribution of estradiol and estrone in human endometrium and myometrium during the menstrual cycle. Contraception $1983,27: 409-421$

25 Vermeulen-Meiners C, Benedek Jaszman LJ, Haspels AA, Poortman J \& Thijssen JH. The endogenous concentration of estradiol and estrone in normal human postmenopausal endometrium. I Steroid Biochem 1984, 21: 607 - 612

26 Vermeulen-Meiners, Poortman J, Haspels AA \& Thijssen JH. The endogenous concentration of estradiol and estrone in pathological human postmenopausal endometrium. J Steroid Biochem 1986, 24: 1073-1078

27 Cunha GR, Bigsby RM, Cooke PS \& Sugimura X. Stromal-epithelial interactions in adult organs. Cell Diff 1985, 17: $137-148$

28 Kratchowil $\boldsymbol{K}$. The stroma and the control of cell growth. J Pathol 1986, 149: 23-24

29 Healy DL \& Hodgen GD. The endocrinology of human endometrium. Obstet Gynecol Surv $1983,38: 509-530$

30 Cooke PS, Uchima F-D, Fujiii DK, Bern HA \& Cunha GR. Restoration of normal morphology and estrogen responsiveness in cultured vagina and uterine epithelia transplanted with stroma. Proc Nat1 Acad Sci USA 1986, 83:2109-2113

31 Bigsby RM \& Cunha GR. Estrogen stimulation of deoxyribonucleic acid synthesis in uterine epithelial cells which lack estrogen receptors. Endocrinol 1986, 119:390-396

32 Roberts DK, Walker NJ \& Lavia LA. Ultrastructural evidence of stromal/epithelial interactions in the human endometrial cycle. An J Obstet Gynecol 1988, 158:854-861

33 Parmly TH, Roberts DK, Walker N.J \& Horbelt DV. Intercellular contacts between stromal cells in the normal endometrium throughout the mensirual cycle. Hum Path 1990, 21: 1063 1066

34 Vollmer G, Siegal GP, Chiquet-Ehrismann R, Lightner VA, Arnoldt H \& Knoppen R. Tenascin expression in the human endonetrium and in endonetrial adenocarcinomas. Lab Invest 1990, 62:725 - 730 
35 Chiquet-Ehrismann $R_{\text {, Mackie E }}$, Pearson CA Sakakura T. Tenascin: an extracelullat matrix protein involved in tissue interactions during fetal development and oncogenesis. Cell $1986,47: 131-139$

36 Buletti C, Galassi A, Jasonni VM, Martinelli G, Tabanell $\mathrm{S}$ \& Flamigni $\mathrm{C}$. Basement membrane components in normal, hyperplastic and neoplastic endometrium. Cancer 1988.62 : $142-149$

37 Visser R, Snijders MP, Arends JW \& Bosman FT. Basenent membrane patterns in the normal, hyperplastic, and neoplastic endonetrum. Submitted for publication

38 Laatikainen $\mathbf{T}$, Andersson B, Kärkkämen $\mathbf{J} \&$ Wahlström $\mathbf{T}$. Progestin receptor levels in endometria with delayed or incomplete secretory changes. Obstet Gynecol 1983, 62: 592- 595

39 Spirtos NJ, Yurewïc EC, Moghïssi KS, Magyar DM, Sundareson AS \& Bottoms SF. Pseudocorpus luteum insufficiency: a study of cytosol progesterone receptors in human endometrium. Obstet Gynecol 1985, 65:535-540

40 Jacobs MH, Balasch J, Gonzalez-Merlo JM et al. Endometrial cytosolic and nuclewr progesterone receptors in the luteal phase defect. J Clin Endocrinol Metab 1987, 64: 472 - 476

41 Aksel S, Saracoglu F, Yeoman RR \& Wiebe RH. Effects of clomiphene citrate on cytosolic estradiol and progesterone receptor concentrations in secretory endometrium. Am J Obstet Gynecol 1986, 155: 1219-1223

42 Abuzeid M, Wiebe HR, Aksel S, Shepherd J \& Yeoman RR. Evidence for a possible cytosol estrogen receptor deficiency in endocervical glands in infertile women with poor cervical mucus. Fertil Steril 1987, 47; 101 - 107

43 Garcia E, Bouchard P, De Brux J et al. Use of immunocytochemistry of progesterone and estrogen receptors for endometrial dating. J Clin Endocrinol Metab 1988, 67:80-87

44 Fox H \& Buckley CH. The endometrial hyperplasias and their relationship to endometrial neoplasia. Histopathology $1982,6: 493-510$

45 Putten van der H. Endometrial hyperplasia and stage I adenocarcinoma. Thesis. Amsterdam, Schriks 1987

46 Kurman RJ, Kaminski PF \& Norris HJ. The bethaviour of endometrial hyperplasia. A longterm study of "untreated' hyperplasia in 170 patients. Cancer 1985, 56: $403-412$

47 Ferenczy A Gelfand M. The biologic significance of cytologic atypia in progestogentreated endometrial hyperplasia. Am. J Obstet Gynecol 1989, 160:126-131

48 Lewandowski G, Tormisi J, Potkul RK et al. Hysterectomy with extended surgical staging and radiotherapy versus hysterectomy alone and radiotherapy in stage I endometrial cancer. a comparison of complication rates. Gyn Oncol 1990, 36: 401-404.

49 Clarke-Pearson D, Cliby W, Soper J et al. Morbidity and monality of selective lymphadenectomy in early-stage endometrial cancer. Gyn Oncol 1991, 40: 168

50 Duk M.J, Aalders JG, Fleuren GJ \& De Bruijn HW. CA 125: A useful marker in endometrial carcinoma. A.m J Obstet Gynecol 1986. 155: 1097-1102

51 Patsner B, Mann WJ, Cohen H \& Loesch M. Predictive value of preoperative serum CA 125 levels in clinically localized and advanced endometrial carcinoma. Am J Obstet Gynceol 1988, 158:399-402

52 Berchuk A, Soisson AP, Clarke-Pearson DL et al. Cellular expression of CA 125 and metastatic potential of endometrial adenocarcinoma. Cancer Res 1989, 49:2091-2095

53 Soper JT, Berchuk A, OIt GJ, Soisson AP, Clarke-Pearson DL \& Bast RC. Preoperative evaluation of serum CA 125, Tag 72, and CA 15-3 in patients with endometrial carcinoma. Am J Obstet Gynecol $1990,163: 1204-1209$ 
54 Aalders JG. Prognostic factors and treatment of endometrial carcinoma. A clinical and histopathological study. Thesis. Groningen, Dijkstra Niemeyer 1982

55 Underwood PB a Taylor PT. Endometrial carcinoma: the role of irradiation. In: Endometrial Cancer. Clintics in Obsterics and Gymaecology 1986, 13:767-789

56 Morrow CP, Bundy BN, Kurman RJ et al. Relationshy between surgical-pathological risk factors and outcome in clinical stage I and II carcinoma of the endometrium: a Gynecologic Oncology Gioup study. Gyn Oncol 1991, 40:55-65

57 Boronow RC. Should whole pelvic radiation therapy become past history? A case for the routine use of extended field therapy and multimodality therapy. Cyn Oncol 1991, 43: 71 - 76

58 Kauppila A. Progestin therapy of endometrial, breast and ovarian carcinoma. A review of clinical observations. Acta Obstet Gynecal Scand 1984, 63: 441 - 450

59 Moore TD, Phillips PH, Nerenstone SR \& Cheson BD. Systemic treatment of advanced and recurrent endometrial carcinoma: current status and future directions. J Clin Oncol 1991, 9: $1071-1088$

60 Borazjani G, Twiggs LB, Leung BS, Prem KA, Adcock LL \& Carson LF. Prognostic significance of steroid receptors measured in primary metastatic and recurrem endometrial carcinoma. A.m J Obstet Gynecol 1989, 161:1253-1257

61 Edmondson JH, Krook JE, Hiton JF et al. Randomized phase II studies of cisplatin and a combination of cyclophosphamide-doxorubicin-cisplatin (CAP) in patients with progestinrefractory adwanced endometria! carcinoma. Gyn Oncol 1987, 28: 20-24

62 Morrow CP, Bundy BN, Homesley HD et al. Doxorubicin as an adjuvant following surgery and radiation therapy in spatients with high-risk endometrial carcinoma, stage I and occult stage II: a Gynecologic Oncology Group study. Gyn Oncol 1990, 36: 166 - 171.

63 Burke TW, Stringer CA, Morris $M$ et al. Prospective treatment of advanced or recurrent. endometrial carcinoma with cisplatin, doxorubicin, and cycophosphamide. Gyn Oncol 1991, 40: $264-267$ 


\section{Summary}

Oestrogen and progesterone receptors are essential mediators of steroid hormones that effect the function of endometrial cells in normal and pathological conditions. Cellular receptor content indicates the potential for hormone responsiveness. The relevance of steroid receptor analysis for clinical management of endometrial cancer is less evident than for breast cancer. Nevertheless, many patients with endometrial cancer are routinely treated with "adjuvant' progestagen therapy. The purpose of this study is to provide a basis for prediction of tumour behaviour. Immunocytochemical receptor analysis may lead to a better clinical management of the individual patient with an endometrial disorder. Therefore, a systematic immunocytochemical analysis of oestrogen and progesterone receptors in the various cell types of normal, hyperplastic, and neoplastic human endometrium has been performed and described in this thesis.

Chapter 1 gives an introduction to the work described in this thesis. Subsequently a short review of oestrogen and progesterone effects on uterine cells, on structure and function of steroid receptors and on methods of steroid receptor analysis is presented, followed by results of relevant steroid receptor studies in the human uterus that are reported in the literature. The aims of the thesis can be summarized as:

- Validation of steroid receptor immunocytochemistry on uterine tissue samples, in particular for the use on routinely-fixed and paraffin-embedded specimens;

- Determination of the cyclic and regional expression of oestrogen and progesterone receptors in the normal uterus during the menstrual cycle, to obtain insight in potential hormonal responsiveness of uterine cells;

- Assessment of steroid receptor distribution in premalignant and malignant huiman endometrium, to find indications for hormonal relationships between stroma and epithelium in the process of malignant transformation;

- Evaluatation of semiquantitative steroid receptor immunocytochemistry for the clinical management of endometrial cancer patients.

The purpose of the study described in chapter 2 was to evaluate tissue and steroid heterogeneity in endometrial carcinoma specimens as a possible source of discordance between cytosolic receptor assay and response to endocrine treatment. Oestrogen and progesterone receptor analysis was performed in specimens from 16 endometrial carcinoma patients on adjacent tissue sections using radiochemical and immunocytochemical assay. Extensive heterogeneity in tissue composition and tumour cell receptor content was observed with immunocytochemistry. Many tumour samples revealed up to $75 \%$ admixture with benign tissue elements. In the majority of cases significant amounts of receptor in normal tissue of the specimen could explain the apparent discordance between semiquantitative immunohistochemical receptor scoring of tumour cells and radiochemical receptor assay. It is concluded that 
immunohistochemical analysis in endometrial carcinoma allows a more specific determination of receptor content of tumour cells and may therefore yield a more accurate prediction of response to endocrine therapy than the cytosolic assay. For a reliable radioreceptor assay stringent histological control is required.

In chapter 3 the methodological development for an immunocytochemical oestrogen and progesterone receptor assay in routinely-fixed, paraffin-embedded uterine sections is described. The purpose was to define the procedures for a reliable semiquantitative receptor analysis. Several techniques to increase the sensitivity of immunostaining were applied, including pretreatment with protein- and DNAsplitting enzymes to expose antigenic sites, adjustment of incubation conditions, and the use of sensitive immunoperoxidase methods. Adjacent tissue blocks were obtained from 35 human endometria. One part was freshly frozen and the other was routinely fixed with $4 \%$ buffered formaldehyde according to standard procedures in the diagnostic pathology laboratory. Regression analysis revealed highly significant linear correlations between receptor scores on frozen and paraffin sections. It was concluded that consistent immunocytochemical receptor staining and quantitation can be achieved using sections from routinely-fixed, paraffin-embedded uterine tissue.

Chapter 4 deals with cyclic and regional changes in steroid receptor expression in the normal uterus. The purpose was to relate these changes with cyclic variations in histomorphology and functional activity. Immunostaining for oestrogen and progesterone receptors in the various cell types of 35 normal uteri was scored for the different phases of the menstrual cycle and postmenopause, and also for the different regions of the corpus and (endo)cervix uteri. During the menstrual cycle, significant changes in oestrogen receptor expression were observed in all uterine cells. The progesterone receptor scores changed significantly in glandular epithelium but not in stromal and smooth muscle cells. No regional variations in steroid receptor distribution in endometrium and myometrium were found. In conclusion, a differential steroid receptor expression between epithelial and stromal cells is found, suggesting autocrine and/or paracrine regulation of functional and morphological changes in these cell types.

In chapter 5, steroid receptor expression in the various stages from hyperplasia to adenocarcinoma was studied. Premalignant stages vary in biological behaviour, clinical course and response to endocrine therapy. Immunocytochemical oestrogen and progesterone receptor staining was quantitated by computerized image analysis in the stromal and epithelial cells of 33 endometrial specimens diagnosed as hyperplasia, atypical hyperplasia and adenocarcinoma. A progressive loss of oestrogen and progesterone receptor content occurred with increasing malignant transformation. The stromal cells in atypical hyperplasia and well-differentiated adenocarcinoma exhibited a relative loss of progesterone receptor content as compared to epithelial cells. In atypical hyperplasia the decrease in stromal progesterone receptor content was not in parallel with persistent stromal oestrogen receptor immunostaining. These observations may reflect a disturbance in the hormonal 
interrelationships between endometrial cells in the development of endometrial neoplasia, indicating that stroma may modulate epithelial growth by paracrine mechanisms.

In chapter 6, preoperative oestrogen and progesterone receptor immunocytochemistry was evaluated to relate the results with clinical and histopathological prognostic factors for 169 endometrial carcinoma patients. Significant inverse correlations were found between immunocytochemical oestrogen and progesterone receptor scores and FIGO stage, pathological stage, depth of myometrial invasion, histological grade, and tumour type. Absent or very low receptor expression appeared to be strongly associated with adverse clinical and histopathological parameters. It is concluded that steroid receptor immunocytochemistry is valuable as preoperative procedure for guidance of surgical-pathological staging in endometrial carcinoma patients.

In chapter 7, steroid receptor immunocytochemistry was related with long term follow-up in 169 patients with endometrial carcinoma. Univariate analysis revealed that, apart from FIGO stage, pathological stage, depth of myometrial invasion, and histological grade, scoring of oestrogen as well as progesterone receptor immunoreactivity significantly predicted long term survival. Multivariate analysis, using the Cox regression model, revealed that both oestrogen and progesterone receptor scoring added significant prognostic information regarding long term survival for patients in all stages of endometrial cancer. It is concluded that incorporation of the results of oestrogen and progesterone receptor immunocytochemistry into a prognostic index should lead to a better identification of different risk groups.

In chapter 8 , the results and conclusions of this study are discussed in a general perspective. Firstly, it is concluded that immunocytochemistry may replace the radioreceptor assay in the near future as it allows receptor visualization and (semi)quantitation at cellular level. Of course, tissue handling, immunostaining and receptor quantification have to be optimized and standardized before steroid receptor immunocytochemistry can be introduced into daily clinical practice. A quality control program should accompany the introduction of this technique.

Secondly, from our observations and other studies on stromal-epithelial interactions it is strongly suggested that local hormonally-controlled mechanisms in and between stromal and epithelial cells are operative in the normal and (pre)neopastic endometrium. Oestrogen related malignant transformation of endometrial hyperplasia may be promoted via stromal factors. In a clinical perspective, receptor immunocytochemistry may become a useful tool to indicate the endocrine relationships in some forms of reproductive failure as well as in proliferative disorders of the endometrium. In this respect it may provide the basis for designing new individualized treatment strategies. Thirdly, steroid receptor immunocytochemistry may inlluence the individualized clinical management of endometrial carcinoma patients. Patients with low or absent receptor immunoreactivity in the preoperative specimen are at higher risk for 
extrauterine extension of cancer and cancer-related death during long term follow $u_{p}$ and thus may potentially benefit from treatment protocols designed for more extensive disease. Prospective studies combining the prognostic value of several histobiological tumour characteristics appear urgently needed. The expression of steroid receptor epitopes can be interpreted as an extra parameter of tumour cell. differentiation, strongly related with tumour behaviour and should be incorporated in the histopathological report of endometrial cancer specimens. 


\section{Samenvatting}

De receptor is het essentiële aangrijpingspunt voor oestrogeen en progesteron, de steroidhormonen die celgroei en -functie van zowel normaal als afwijkend baarmoederslijmvlies (endometrium) beinvloeden. Het receptorgehalte geeft een indruk over de specifieke hormoongevoeligheid van de betreffende cel. Voor baarmoederslijmvlieskanker (endometriumcarcinoom) is de klinische betekenis van receptoranalyse tot nog toe echter minder duidelijk dan voor borstkanker. Desondanks wordt hormonale (progestatieve) therapie bij patienten met een endometriumcarcinoom vaak en ook routinematig toegepast. Het doel van deze studie is te voorzien in een methodiek, waarmee het biologisch gedrag van endometrium-(tumor)cellen beter kan worden voorspeld. Gebruikmakend van immunochemische technieken zou de analyse van receptoren op celniveau kunnen leiden tot een betere, meer op het individu afgestemde behandeling van de patient met een afwijkend endometrium. In dit proefschrift wordt het immunocytochemisch onderzoek van oestrogeen- en progesteronreceptoren in de verschillende celtypen van respectievelijk normaal, hyperplastisch-praemaligne en maligne endometrium beschreven.

Hoofdstuk 1 geeft een algemene inleiding op het in dit proefschrift beschreven onderzoek. Achtereenvolgens worden geresumeerd: effecten van oestrogeen en progesteron op endometriumcellen, structuur en functie van hormoonreceptoren, methoden waarmee hormoonreceptoren kunnen worden aangetoond, en tenslotte de in de literatuur gerapporteerde resultaten van receptoronderzoek in humaan baarmoederweefsel. Hieropvolgend worden de afzonderlijke doelstellingen van het onderzoek geformuleerd:

- Validatie van oestrogeen- en progesteronreceptor immunocytochemie voor toepassing op baarmoederweefsel, met name op routinematig gefixeerd paraffinemateriaal.

- Analyse van cyclische en regionale patronen in receptor-expressie gedurende de menstruele cyclus, ten einde meer inzicht te verkrijgen in de specifieke hormoongevoeligheid van de verschillende celtypen in de normale uterus.

- Analyse van receptorexpressie in de stromale en epitheliale cellen van hyperplastische, praemaligne en maligne endometria, ter verduidelijking van specifiek hormonale invloeden op het proces van kwaadaardige ontaarding.

- Evaluatie van de klinische betekenis van immunocytochemische receptoranalyse voor prognose en behandeling van patienten met een endometriumcarcinoom.

In hoofdstuk 2 was het onderzoek gericht op de heterogene samenstelling van endometriumcarcinomen als mogelijke oorzaak voor de sterk wisselende correlatie tussen resultaten van radiochemische receptoranalyse enerzijds en respons op hormoontherapie anderzijds. Oestrogeen- en progesteronreceptoren werden zowel radiochemisch als immunocytochemisch geanalyseerd op aansluitende weefselcoupes bij 
16 patienten mer endometriumcarcinoom. Met behulp van immunocytochemische analyse werd aanzienlijke heterogeniteit waargenomen, zowel wat betreft weefselsamenstelling als receptorverdeling. Alle coupes van endometriumcarcinomen bevatten goedaardige weefselpartikels, in een aantal gevallen tot wel $75 \%$ ! In het merendeel van de gevallen waarbij er een discrepantie bestond tussen de immunocytochemische receptorscore van de tumorcellen en de radiochemische resultaten, kon deze verklaard worden door interferentie van receptorconcentraties uit omgevend goedaardig weefsel. De conclusie luidt derhalve, dat voor het endometriumearcinoom de (semi)quantitatieve immunocytochemische analyse superieur is aan de radiochemische, daar eerstgenoemde duidelijker informeert over het receptorgehalte wan de specifieke (tumor)cel en zo mogelijk de respons op hormonale therapie beter voorspelt. Voor elke radiochemische analyse geldt, dat stringente histologische controle van het te onderzoeken monster een eerste vereiste is.

De methodologische aspecten van oestrogeen- en progesteronreceptor immunocytochemie op paraffinecoupes worden behandeld in hoofdstuk 3 . Het doel van het onderzoek betrof een betrouwbare (semi)quantitatieve receptoranalyse te ontwikkelen, welke kan worden toegepast op paraffinecoupes van routinematig gefixeerd materiat. Ten einde de specifieke receptorkleuring te intensiveren werden verschillende technieken toegepast, zoals voorbehandeling met eiwit- en DNA-splitsende enzymen welke het receptorantigeen meer bloot stellen aan het monoclonale antilichaam, aanpassing van de incubatietijden en het gebruik van uiterst gevoelige immunoperoxidasen. Het onderzoek werd uitgevoerd op coupes van direct naast elkaar uitgesneden weefselblokjes van 35 operatief verwijderde humane uteri. Eén blokje werd terstond ingevroren, terwijl het ander routinematig werd verwerkt volgens de algemeen gangbare procedure in een pathologisch laboratorium, d.w.z. gefixeerd in $4 \%$ gebufferde formaline waarna in paraffine ingebed. De (semi) quantitatieve receptorscores op vries- en paraffinecoupes bleken bij regressieanalyse onderling statistisch significant te correleren. Geconcludeerd werd dat een consistente immunocytochemische receptorkleuring en -quantificering kan worden verkregen op paraffinecoupes van routinematig gefixeerd baarmoederweefsel.

De analyse van cyclische en regionale receptorpatronen in de normale uterus wordt beschreven in hoofdstuk 4 . Het doel van de studie was, de waargenomen patronen te relateren aan de cyclische veranderingen in histomorphologie en functionele activiteit van de verschillende coltypen. Hiertoe werd het oestrogeen- en progesterongehalte gek wantificeerd in de afzonderlijke celtypen van 35 normale uteri gedurende de verschillende fasen van de menstruele cyclus en postmenopause, en tevens op de verschillende niveau's van baarmoederlichaam en -hals. In de bestudeerde celtypen bleek het oestrogeenreceptorgehalte statistisch significant te verschillen gedurende de opeenvolgende fasen van de menstruele cyclus. Een significante verandering bleek eveneens waarneembaar voor de concentratie aan progesteronreceptoren in het khierbuisepitheel, echter niet in het endometriale stroma en de gladde spiercellen van het myometrium. Een significante variatie in verdeling van receptoren over de verschillende niveau's van baarmoederlichaam en -hals kon niet worden aangetoond. 
De waargenomen verschillen in hormoonreceptorexpressie tussen epithehale en stromale cellen suggereren autocriene (vanuit de cel zelf) en/of paracriene (van cel op cel) regulatie van morphologische en functionele veranderingen in deze endometrale celtypen gedurende de normale menstruele cyclus.

Abnormale proliferatie van het endometrium kent een aantal verschijningsvormen welke van elkaar verschillen in biologisch (tumor)gedrag, klinisch beloop en respons op hormoontherapie. De studie van hormoonreceptoren in de verschillende vormen van endometriumhyperplasie en -adenocarcinoom wordt beschreven in hoofdstuk 5 . De verdeling van oestrogeen- en progesteronreceptoren in stromale en epitheliale cellen werd met behulp van gecomputeriseerde beeldanalyse gequantificeerd in 33 endometria, die achtereenvolgens waren geclassificeerd als hyperplasie, atypische hyperplasie en adenocarcinoom graad I-III. Een consequente en statistisch significante daling in zowel oestrogeen- als progesteronreceptorgehalte werd geconstateerd bij toenemend maligne ontaarding. Echter, vergeleken met de epitheliale cellen toonden de stromale cellen in atypische hyperplasie en goed-gedifferentieerd (graad I) adenocarcinoom een veel sterker verlies aan progesteronreceptor expressie. Bovendien bleek in atypische hyperplasie een significant verlies an stromale progesteronreceptorconcentratie te contrasteren met een min of meer gelijkblijvend oestrogeenreceptorgehalte. Deze onderzoeksresultaten suggereren locale verstoring van de hormonale interactie tussen beide celtypen ten tijde van maligne ontaarding. Invasieve groei van atypische epitheelcellen lijkt niet alleen direct, maar tevens indirect oestrogeen-geinduceerd via stromale (groei?) factoren.

In hoofdstuk 6 worden, uit een serie van 169 endometriumcarcinomen, de resultaten van receptoranalyse in het diagnostisch curettageweefsel vergeleken met de klinisch en histopathologisch prognostische factoren ma chirurgisch/pathologische stagering. Statistisch significante inverse correlaties werden gevonden tussen oestrogeen- en progesteronreceptorscores enerzijds en FIGO stagering, pathologisch stadium, myometriumingroei, differentiatiegraad en tumortype anderzijds. Geen dan wel minimale receptorexpressie bleek sterk gecorreleerd met prognostisch ongunstige factoren. Geconcludeerd werd dat, naast de histologische subtypering en gradering, de analyse van steroidreceptoren een waardevolle aanwinst betekent voor classilicatie van het specifieke tumorgedrag. Met deze aanvullende informatie voorhanden, zou vervolgens de chirurgische behandeling c.q. stagering van het endometriumcarcinoom op betere gronden kunnen worden aangepast aan de individuele patient.

Het follow-up onderzoek naar de relatie tussen resultaten van receptoranalyse en overleving wordt beschreven in hoofdstuk 7 . Naast de reeds bekende parameters FIGO stadium, pathologisch stadium, mate van myometriumingroei en differentiatiegraad, waren zowel oestrogeen- als progesteronreceptorscore statistisch significant gecorreleerd met de overlevingsduur. Bij multivariate analyse (m.b.v. Cox regressie) bleek, dat zowel de oestrogeen- als de progesteronreceptorscore onafhankelijk statistisch significante waarde toevoegen als prognostische parameters. Het lijkt derhalve aangewezen de resultaten van receptoranalyse toe te voegen aan het arsenaal van 
prognostische factoren, daar hiermede de verschillende risicogroepen beter kunnen worden onderscheiden.

Hoofdstuk 8 betreft een algemene discussie van de onderzoeksresultaten en conclusies. Allereerst wordt vastgesteld, dat binnen afzienbare tijd de immunocytochemische analyse de radiochemische receptorassay zal vervangen, daar eerstgenoemde de receptor niet alleen direct zichtbaar maakt op celniveau maar tevens (semi)quantificering in weefselcoupes toestaat. Uiteraard dienen de voorschriften ten aanzien van weefselopvang en -fixatie, immunochemische kleuring en receptor quantificering te worden gestandaardiseerd, alvorens de receptor immunocytochemie algemeen kan worden toegepast als diagnostische procedure. Daarnaast behoort een systeem van kwaliteitscontrole de introductie wan een dergelijke techniek te vergezellen.

Uit de resultaten van deze en andere studies kan vervolgens worden geconcludeerd, dat hormonaal gestuurde interactie tussen stromale en epitheliale cellen een belangrijke rol speelt in zowel normaal als (prae)maligne endometrium. Maligne transformatie van epitheelcellen, welke veroorzaakt kan worden door continue oestrogene stimulatie, lijkt indirect gestimuleerd via stromale factoren. Receptor immunocytochemie kan worden toegepast op weetselbiopten ter aanvullende diagnostiek bij gestoorde vruchtbaarheid of abnormale endometriumproliferatie. Meer gedetailleerde informatie kan zodoende worden verkregen over een verstoring van het locale 'endocriene milieu' in het endometrium. Vervolgens kan hormonaal corrigerende therapie op betere gronden worden geadviseerd en geëvalueerd.

Tenslotte lijkt de receptor immunocytochemie van belang voor een meer individuele behandeling van de patient met baarmoederkanker. Patienten met geen of slechts minimale receptorexpressie in het diagnostisch curettageweefsel blijken 'at risk' voor extra-uteriene uitbreiding van de tumor én overlijden ten gevolge van de ziekte. Een dergelijke patient kan derhalve gebaat zijn bij meer intensieve behandeling en controle. Prospectieve onderzoeken welke de prognostische waarde van deze en andere histobiologische tumorkarakteristiek(en) evalueren zijn gewenst. Binnen dit kader kunnen de oestrogeen- en progesteronreceptorexpressie worden beschouwd als extra parameters van tumorceldifferentiatie, sterk gerelateerd aan tumorgedrag. Het lijkt aangewezen de resultaten van immunocytochemische receptoranalyse in de histopathologische verslaggeving van het endometriumcarcinoom op te nemen. 


\section{Curriculum Vitae}

1959 geboren te Nieuwenhagen op $30 \mathrm{mei}$

1977 eindexamen gymnasium B, St Bernardinuscollege Heerlen

1977 studie geneeskunde, Rijksuniversiteit Utrecht

1980-1982 student-assistent Pathologie

1985 artsexamen

1985-1986 assistent geneeskundige (niet in opleiding), afdeling Gynaecologie \& Verloskunde, De Wever-Ziekenhuis Heerlen

1986-1990 niet-universitaire A-opleiding tot vrouwenarts, De Wever-Ziekenhuis Heerlen (opleiders dr L.A. Schellekens, dr J.E.G.M. Stoot)

1988 'Award for Best Presentation', 3rd Meeting of the European Association of Gynaecologists \& Obstetricians, Nijmegen ('Semi-quantitative immunohistochemical analysis of estrogen and progesterone receptors in normal and malignant human endometrium')

1990-1991 universitaire A-opleiding tot vrouwenarts, academisch ziekenhuis Maastricht (opleider prof. dr J. de Haan)

1991 Van Berckel wetenschapsprijs, De Wever-Ziekenhuis, Heerlen ('Immunocytochemische analyse van oestrogeen- en progesteronreceptoren in het endometrium')

1991 inschrijving in specialistenregister op 1 juni

1991-1992 chef de clinique gynaecologie, st Maartens Gasthuis, Venlo

1992 lid Maatschap Gynaecologie (in associatie met dr H.F. van Geuns, dr F.A. Boschma \& drs C.G.M. de Rooij), st Maartens Gasthuis, Venlo, vanaf 1 juni 
The publication of this thesis was financially supported by:

- Resenachfonds De Wever-Ziekenhus

- Abbort

- Becton Dickinason

- Brisol-Myess Squibb

- Bisk

- Farmitalia

- Hoechsot

- Novo Nordisk

- Sanofi Winthrop

- Schering

- Cuba

- Upjohn! 